\title{
TOWARDS THE SYNTHESIS OF PHOTOBACTIN: METHODOLOGY AND METAL BINDING ASPECTS
}

\author{
by \\ Michelle Shuoprasad \\ Bachelor of Science, Chemistry \\ Ryerson University, Toronto, Ontario, Canada, 2011
}

A thesis presented to Ryerson University

In partial fulfillment of the requirements for the degree of Master of Science in the Program of Molecular Science

Toronto, Ontario, Canada, 2014

(C) Michelle Shuoprasad 2014 


\section{Author's Declaration}

I hereby declare that I am the sole author of this thesis. This is a true copy of the thesis, including any required final revisions, as accepted by my examiners.

I authorize Ryerson University to lend this thesis to other institutions or individuals for the purpose of scholarly research.

I further authorize Ryerson University to reproduce this thesis by photocopying or by other means, in total or in part, at the request of other institutions or individuals for the purpose of scholarly research.

I understand that my thesis may be made electronically available to the public.

X M.Shuoprasad

Michelle Shuoprasad 


\title{
Abstract
}

\section{TOWARDS THE SYNTHESIS OF PHOTOBACTIN: METHODOLOGY AND METAL BINDING ASPECTS}

\author{
by Michelle Shuoprasad \\ Molecular Science \\ Master of Science, Ryerson University, 2014
}

Siderophores are metal-typically iron-chelating compounds that have received countless attention in research, as they can play a role in medicine intended for drug delivery and iron overload treatment. The synthesis of Photobactin has been of interest as it has been previously isolated ( $<10 \mathrm{mg}$ ) from Photorhabdus luminescence and has not once been synthesized. This thesis examined the preparation of Photobactin using a multi-step approach: synthesizing two building blocks individually and coupling them together with an amide coupling reagent. Both building blocks were synthesized successfully. However, the deprotection of the ester group on one of the building blocks has been uncooperative, and therefore the total synthesis of Photobactin was not achieved. Moreover, DFT computation calculations were performed to study Photobactin binding properties with $\mathrm{Fe}^{3+}$. According to the results, iron $\left(\mathrm{Fe}^{3+}\right)$ is likely to form a hexadentate (6-coordinate ligand) or a tetradentate (4-coordinate ligand) complex with Photobactin.

Each of the compounds leading to Photobactin was characterized using ${ }^{1} \mathrm{H}$ and ${ }^{13} \mathrm{C}-\mathrm{NMR}$. Some compounds were characterized using elemental analysis and performing 2D-NMR (COSY, HMBC, and HSQC) to make final assignments. 


\section{Acknowledgements}

It is a pleasure to thank the many people who made this thesis possible.

I would first like to express my special gratitude and thanks to my supervisor, Dr. Robert

Gossage, for taking me in as his student. Throughout this thesis research he has provided support, patience, guidance, and assistance. Thank you Dr. Gossage.

I would like to thank my committee members Dr. Russell Viirre and Dr. Daniel Foucher for their assistance and sharing their knowledge with me. I would also like to thank Dr. Andrew McWilliams for taking the time to read my thesis.

My sincere thanks to Dr. Bryan Koivisto for challenging me, since the day he came to Ryerson University. I am more critical in my writing because of him, and he has given me advice when I needed it, even though I was not his student. So I thank him for his kind assistance.

Khrystyna Herasymchuk, thank you for putting up with me for three years, I bet it was not that easy. You have been an amazing friend and you were always there when I needed you. I will miss working with you in the lab. All the best.

Gossage Group and my lab mates (from KHN 202, KHN 209, KHE 322C) thanks for your assistance in the lab, I appreciated it. Lab would be lonely and not entertaining without you guys (Aman, Lucas, Grace, Shane, Maryam, and Krimo).

I would also love to thank my friends for helping me get through these couple of years, for all the emotional support, and valuable advice. I genuinely appreciate your belief in me. Love you all-Carolyn Khalil, Dulce Banegas, Sossina Gezahegn, Katie Lyashkevich, Pegah Baratzadeh, and Nick Tulsiram (cousin).

Finally, I wish to thank my parents Minawatie and Moonilal, my brother Kevin, and my sister Christina. Thank you for your support, patience, and love throughout this thesis project. 
To my immediate family

\section{"The Shuoprasads"}




\section{Table of Contents}

CHAPTER $\quad$ PAGE

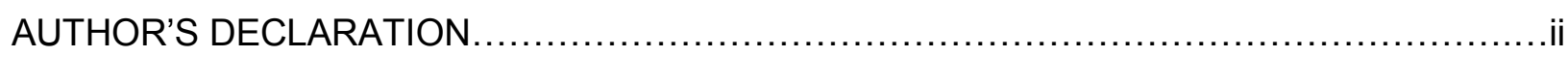

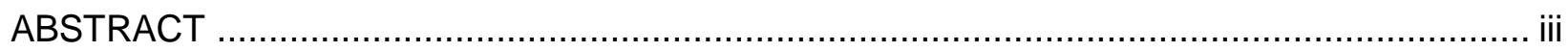

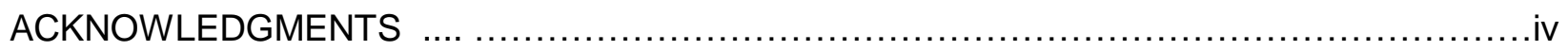

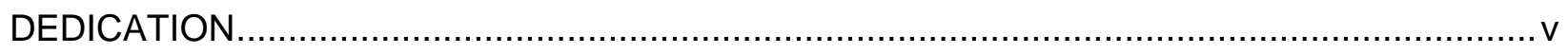

LIST OF TABLES …………………............................................................................ii

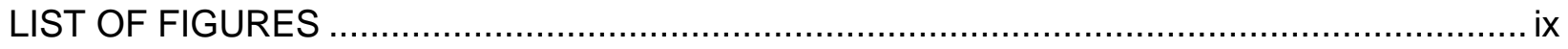

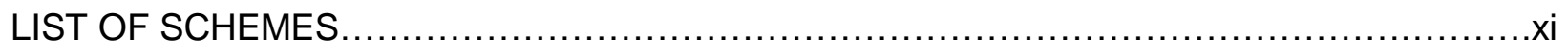

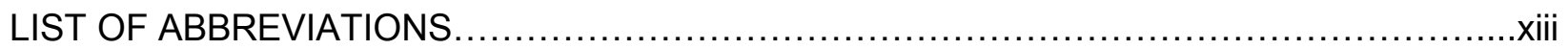

CHAPTERS

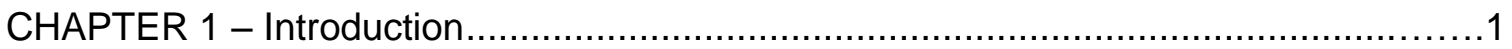

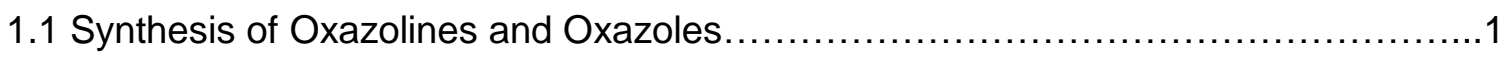

1.2 Natural Occurring Oxazolines and Their Biological Roles..............................

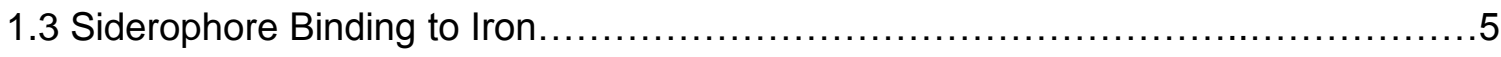

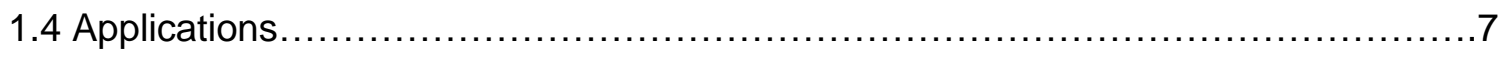

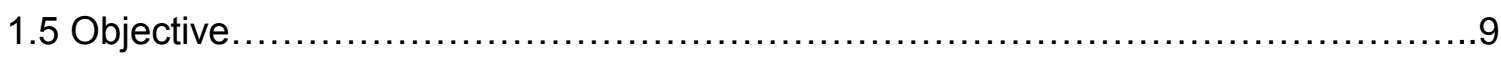

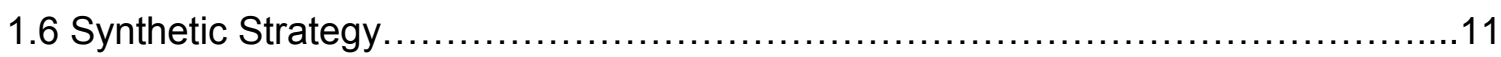

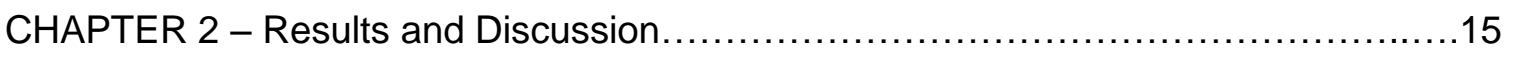

2.1 Synthesis of L-Threonine Methyl and Benzyl Ester...................................15

2.1.1 L-Threonine Methyl Ester Hydrochloride (1) ................................16

2.1.2 L-Threonine Benzyl Ester (2) ...........................................17

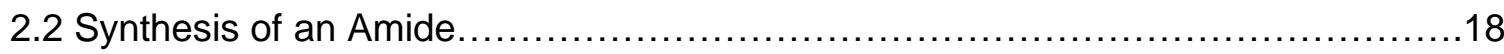

2.2.1 $\mathrm{N}$ - $(o, m)$-Dimethoxybenzoyl-L-threonine methyl ester (3) ...................18

2.2.2 $\mathrm{N}$ - $(o, m)$-Dimethoxybenzoyl-L-threonine benzyl ester (4) ....................19

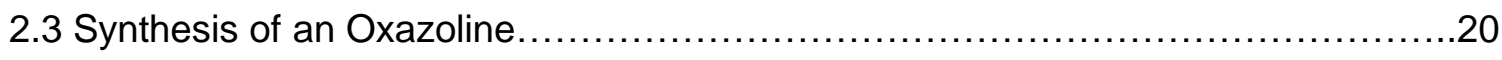


2.3.1 ((4S, 5R)-2-(o, m)-Dimethoxyphenyl)-5-methyl-4-oxazolinecarboxylic acid methyl ester (5).

2.3.2 ((4S, 5R)-2-(o, m)-Dimethoxyphenyl)-5-methyl-4-oxazolinecarboxylic acid benzyl ester (6) .23

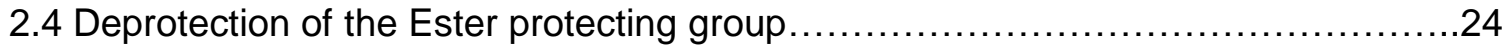

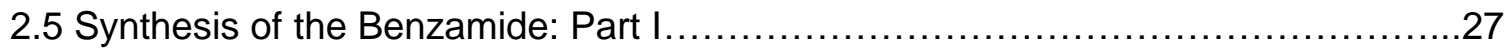

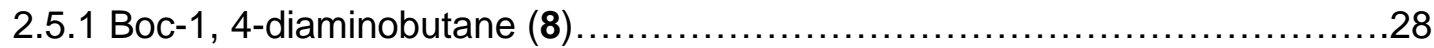

2.5.2 N-Boc (1, 4-aminobutyl)-2, 3-(dimethoxyphenyl) benzamide (9)............. 28

2.5.3 N-Boc (1, 4-aminobutyl)-[2, 3-bis (benzyloxy) phenyl] benzamide (10).......29

2.6 Deprotection of Boc Protecting Group..........................................

2.6.1 1, 4-aminobutyl)-[2, 3-bis (benzyloxy) phenyl] benzamide (11)..............32

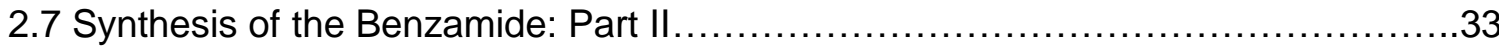

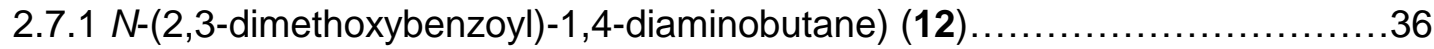

2.7.2 N,N-Bis(2,3 -bis(methoxy)benzoyl) diaminobutane (13) ...................37

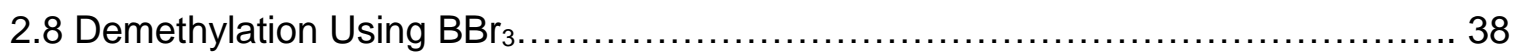

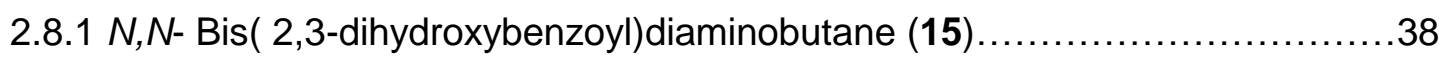

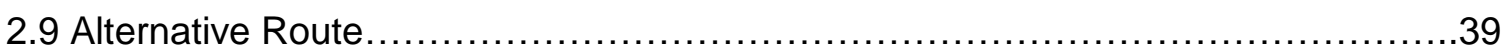

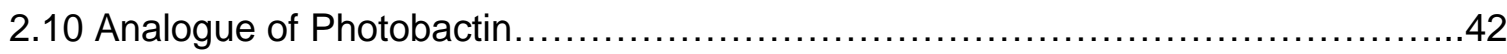

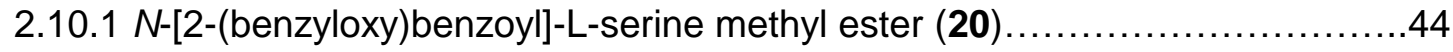

2.10.2 (S)-Methyl 2-[2-Benzyloxy)phenyl]-1,3-oxazoline-4-carboxylate (21) ..........45

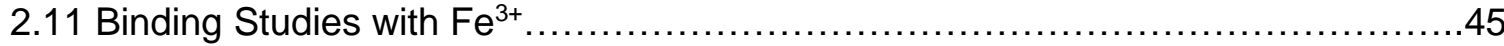

CHAPTER 3 - Conclusion and Future Work ...................................49

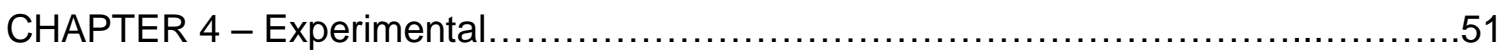

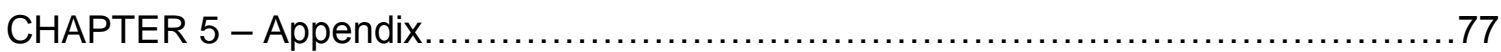

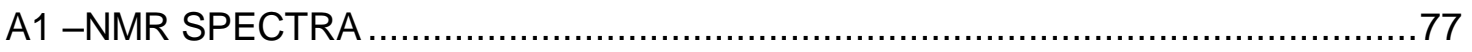

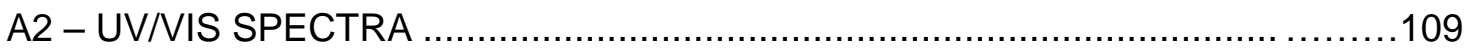

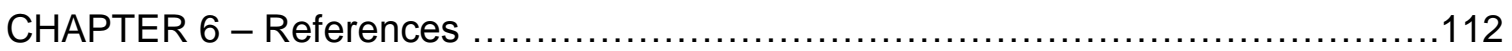




\section{List of Tables}

Table 1 Different Methods Used to Synthesize Oxazoline

Table 2 Attempts of Deprotection of Methyl Ester using Different Methods

Table 3 Attempts of Deprotection of Benzyl Ester using Different Methods

Table 4 Different Methods used to cleave Boc

Table 5 Reaction conditions for N-(2,3-dimethoxybenzoyl)-1,4-diaminobutane synthesis 


\section{List of Figures}

Figure 1.1.1 Oxazoline (i), Oxazole (ii), Hydroxyphenyl oxazoline (Hphox) (iii)

Figure 1.2.1 Siderophore mediated iron availability

Figure 1.2.2a Structures of siderophores that contain the Hphox Unit

Figure 1.2.2b Structures of siderophores that contain the Hphox Unit

Figure 1.3.1 Binding constant reaction/ equation

Figure 1.3.2 Other ligand motifs common in siderophores

Figure 1.3.3 Ferric Agrobactin $(\mathrm{R}=\mathrm{OH})$ and Ferric Parabactin $(\mathrm{R}=\mathrm{H})$

Figure 1.3.4 The structure of Serratiochelin

Figure 1.3.5 Resonance structure of an oxazoline

Figure 1.4.1: The structure of Transvalencin $Z$

Figure 1.4.2: The structure of Photobactin

Figure 2.2.1 The structure of $\mathrm{EDC} \cdot \mathrm{HCl}$

Figure 2.4.1 Deprotection of Bn ester using a balloon filled with $\mathrm{H}_{2}$

Figure 2.5.1 Common protecting groups for amines

Figure 2.6.1: Comparing ${ }^{1} \mathrm{H}-\mathrm{NMR}$ spectra of Boc (10) and No Boc (11)

Figure 2.7.1: Structures of $\mathrm{CDI}$ and HBTU 
Figure 2.7.2: Compound 13 is formed when using $\mathrm{HBTU}$ or $\mathrm{SOCl}_{2}$

Figure 2.7.3: Compound 13 (top spectrum - using HBTU) Vs. N(2,3-dimethoxybenzoyl)diaminobutane) (12) (bottom spectrum-using DMTMM) in $\mathrm{CDCl}_{3}$

Figure 2.10.1 Structure of Photobactin and the analogue of Photobactin

Figure 2.11.1 Orbital energy of compound (15) calculated using

Figure 2.11.2: $\quad$ Possible Fe-Photobactin complexes calculated using DFT (B3LYP/6-31G*) 


\section{List of Schemes}

$\begin{array}{lll}\text { Scheme } 1 & \text { Typical synthesis of oxazolines } & 1\end{array}$

Scheme 2 Robinson-Gabriel synthesis 2

Scheme 3 Fischer oxazole synthesis 2

Scheme 4 Cornforth rearrangement 2

Scheme $5 \quad$ Synthesis of Acinetobactin 12

Scheme 6 Synthesis of Mycobactin S from two building blocks 13

Scheme 7 Proposed synthesis of Photobactin-a two building block approach 14

Scheme $8 \quad$ Synthesis of L-Threonine methyl ester (1) 15

$\begin{array}{lll}\text { Scheme } 9 & \text { Synthesis of L-Threonine benzyl ester (2) } & 16\end{array}$

$\begin{array}{lll}\text { Scheme } 10 & \text { Synthesis of an amide (3 and 4) } & 18\end{array}$

$\begin{array}{lll}\text { Scheme } 11 & \text { The synthesis of an oxazoline } & 20\end{array}$

Scheme 12 The mechanism of an amide to a nitrile by an E2 elimination 20

Scheme 13 Cyclodehydration of $\beta$-hydroxy amide to oxazoline 22

Scheme $14 \mathrm{Mo}(\mathrm{VI})=\mathrm{O}$ catalyst used to synthesize an oxazoline 22

Scheme 15 Deprotection of methyl and benzyl ester from the $1^{\text {st }}$ building block 25

Scheme 16 Synthesis of Boc-1,4-diaminobutane 28 
Scheme 17 Synthesis of compound (9) and (10)

Scheme 18 General mechanism of deprotection of Boc

Scheme 19 Synthesis of $\mathrm{N}$-(2,3-dimethoxybenzoyl)diaminobutane (12) using a coupling reagent

Scheme 20 Synthesis of DMTMM (14)

Scheme 21 Mechanism of demethylation using $\mathrm{BBr}_{3}$

Scheme 22 Demethylation of compound 13

Scheme 23 An alternative approach to synthesize Photobactin

Scheme 24 Synthesis of ethyl 2,3-dihydroxybenzimidate (19)

Scheme 25 Synthesis of compound 21 via Burgess reagent

Scheme 26 Using Burgess reagent to yield an oxazoline

Scheme 27 The results from proposed synthesis of Photobactin 


\section{List of Abbreviations}

\begin{tabular}{|c|c|}
\hline ACN & Acetonitrile \\
\hline atm & Atmosphere \\
\hline $\mathrm{BBr}_{3}$ & Boron tribromide \\
\hline $\mathrm{BnOH}$ & Benzyl alcohol \\
\hline Boc & tert-Butyloxycarbonyl \\
\hline $\mathrm{Boc}_{2} \mathrm{O}$ & Di-tert-butyl dicarbonate \\
\hline $\mathrm{Bu}_{4} \mathrm{NF}$ & Tetra- $n$-butylammonium fluoride \\
\hline $\mathrm{C}_{6} \mathrm{H}_{6}$ & Benzene \\
\hline $\mathrm{Cbz}$ & Carboxybenzyl \\
\hline CDI & Carbonyldiimidazole \\
\hline $\mathrm{CD}_{3} \mathrm{OD}$ & Deuterated methanol \\
\hline $\mathrm{CDCl}_{3}$ & Deuterated chloroform \\
\hline CDMT & 2-chloro-4,6-dimethoxy-1,3,5-triazine \\
\hline $\mathrm{CHCl}_{3}$ & Chloroform \\
\hline CN & Coordination number \\
\hline DCM & Dichloromethane \\
\hline DEAD & Diethyl azodicarboxylate \\
\hline DFT & Density Functional Theory \\
\hline DMTMM & $\begin{array}{l}\text { 4-(4,6-Dimethoxy-1,3,5-triazin-2-yl)-4-methylmorpholinium } \\
\text { chloride }\end{array}$ \\
\hline $\mathrm{D}_{2} \mathrm{O}$ & Deuterium oxide \\
\hline $\mathrm{EDC} \cdot \mathrm{HCl}$ & $\begin{array}{l}N \text {-(3-Dimethylaminopropyl)-N'-ethylcarbodiimide } \\
\text { hydrochloride }\end{array}$ \\
\hline
\end{tabular}




\begin{tabular}{|c|c|}
\hline $\mathrm{Et}_{2} \mathrm{O}$ & Diethyl ether \\
\hline $\mathrm{Et}_{3} \mathrm{~N}$ & Triethylamine \\
\hline EtOAc & Ethyl acetate \\
\hline EtOH & Ethanol \\
\hline $\mathrm{FeCl}_{3}$ & Iron (III) chloride \\
\hline F-moc & 9-Fluorenylmethyloxycarbonyl \\
\hline $\mathrm{H}_{2}$ & Hydrogen (gas) \\
\hline HBTU & $\begin{array}{l}N, N, N^{\prime}, N^{\prime} \text {-Tetramethyl-O- }(1 H \text {-benzotriazol-1-yl)uronium } \\
\text { hexafluorophosphate }\end{array}$ \\
\hline $\mathrm{HCl}$ & Hydrochloric acid, Hydrogen chloride \\
\hline HOBt & Hydroxybenzotriazole \\
\hline номо & Highest Occupied Molecular Orbital \\
\hline hrs & hours \\
\hline $\mathrm{K}_{2} \mathrm{CO}_{3}$ & Potassium carbonate \\
\hline LG & Leaving group \\
\hline LiOH & Lithium hydroxide \\
\hline LMCT & Ligand-Metal Charge Transfer \\
\hline LUMO & Lowest Unoccupied Molecular Orbital \\
\hline $\mathrm{MeOH}$ & Methanol \\
\hline Methyl DAST & (Dimethylamino)sulfur trifluoride \\
\hline Min & Minute(s) \\
\hline $\mathrm{MgSO}_{4}$ & Magnesium sulfate \\
\hline $\mathbf{N}_{2}$ & Nitrogen (gas) \\
\hline $\mathrm{Na}_{2} \mathrm{CO}_{3}$ & Sodium carbonate \\
\hline $\mathrm{NaHCO}_{3}$ & Sodium bicarbonate \\
\hline
\end{tabular}




\begin{tabular}{|c|c|}
\hline $\mathrm{NaOH}$ & Sodium hydroxide \\
\hline $\mathrm{NH}_{4} \mathrm{OH}$ & Ammonium hydroxide \\
\hline NMM & $N$-Methylmorpholine \\
\hline NMR & Nuclear Magnetic Resonance \\
\hline $\mathrm{O} / \mathrm{N}$ & Overnight \\
\hline $\mathbf{P P h}_{3}$ & Triphenylphosphine \\
\hline RT & Room temperature \\
\hline SEM & 2-(Trimethylsilyl)ethoxymethyl \\
\hline $\mathrm{SO}_{2}$ & Sulfur dioxide \\
\hline $\mathrm{SOCl}_{2}$ & Thionyl chloride \\
\hline TBDPS & tert-Butyldiphenylsilyl \\
\hline TFA & Trifluoroacetic acid \\
\hline TLC & Thin Layer Chromatography \\
\hline TMSCl & Trimethylsilyl chloride \\
\hline UV-Vis & Ultraviolet-Visible Spectroscopy \\
\hline$\varepsilon_{\max }$ & Molar absorptivity \\
\hline$\lambda_{\max }$ & Absorbance peak (maximum) \\
\hline
\end{tabular}




\section{Introduction}

\subsection{Synthesis of Oxazolines and Oxazoles}

Oxazolines and Oxazoles (i \& ii respectively: Figure

1.1.1) belong to a class of heterocyclic compounds which continue to be of great interest in all aspects of synthetic chemistry. This is supported by a continuous growth in the number of research publications and reviews that focus on the chemical and biological importance of oxazolines and<smiles>C1=NCOC1</smiles>
i<smiles></smiles>
ii<smiles>[R]c1cccc(C2=NCCO2)c1O</smiles>

$\mathrm{R}=\mathrm{OH} / \mathrm{H}$

Figure 1.1.1: Oxazoline (i), Oxazole (ii), Hydroxyphenyl oxazoline (Hphox) (iii) oxazoles, since the early 1980's. The continued interest in these compounds are mainly due to their simple synthetic preparation. There are several known synthetic routes to oxazolines, but<smiles>[R]C#N</smiles>

$\Delta$

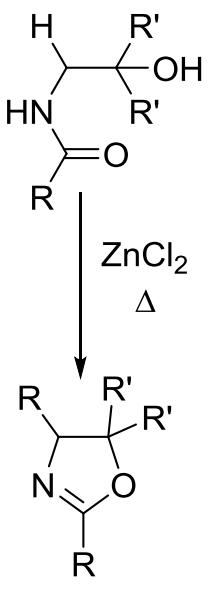

oxazoline

Scheme 1: Typical synthesis of oxazolines

the two most common approaches are summarized in Scheme 1. Readily available $\beta$-amino alcohols can be coupled with an acid chloride to yield an amide, which is then cyclized to the oxazoline in the presence of a Lewis acid catalyst. ${ }^{1}$ This method requires two steps. Alternatively, the one step synthesis of oxazoline can be achieved by reacting a $\beta$-amino alcohol with a nitrile, also under Lewis acid catalysis. ${ }^{1}$ There are various other procedures that have been developed for the

preparation of 2-substituted oxazolines using carboxylic acid, carboxylic ester, aldehydes, and olefins as starting materials. However, most of the methods have numerous disadvantages which includes strongly acidic conditions, toxic solvents, long reaction times, use of complex reagents, and low yield of products. 
<smiles>[R]C(=O)CNC([R])=O</smiles>

$$
\mathrm{R=} \underset{-\mathrm{H}_{2} \mathrm{O}}{\stackrel{\mathrm{H}_{2} \mathrm{SO}_{4}, \mathrm{RT}}{\longrightarrow}}
$$

Scheme 2: Robinson-Gabriel synthesis
Oxazolines can also be prepared by reducing oxazoles. There are three common synthetic routes to oxazoles. The primary synthetic route is the dehydration of 2-acylamino-ketones, also known as Robinson-Gabriel synthesis (Scheme 2). ${ }^{2}$ In this reaction, concentrated sulphuric acid or phosphorus pentachloride is used as the dehydration agent; typically sulphuric acid gives better yields and produces fewer by-products. ${ }^{2}$

Another route to oxazoles is the Fischer synthesis (Scheme 3). This reaction involves the acidified condensation of equimolar amounts of cyanohydrins and aromatic aldehyde in dry ether. ${ }^{3}$ This synthesis was discovered by Hermann Emil Fischer in 1896, who found that 2,5-diphenyloxazole hydrochloride precipitated when $\mathrm{HCl}$ was passed through an

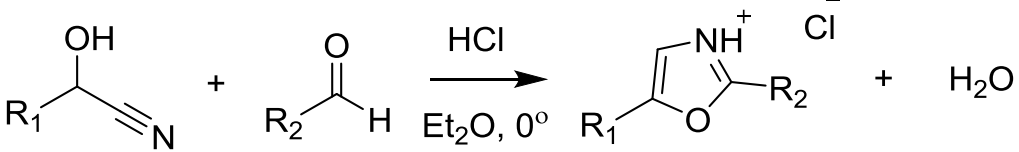
absolute ether solution of $\mathrm{R}_{1}, \mathrm{R}_{2}=$ alkyl, aryl, heteoaryl, $\mathrm{H}$, halogen benzaldehyde and benzaldehyde Scheme 3: Fischer oxazole synthesis cyanohydrins. ${ }^{3}$ This synthetic route is typically high yielding ( 80\%).

Another common reaction generating substituted oxazole is the Cornforth Rearrangement which is shown in Scheme 4. Cornforth rearrangement is a thermal interconversion of 4-carbonyl substitute oxazoles with exchange between the $\mathrm{C}-\mathrm{C}=\mathrm{O}$ side chains and $\mathrm{C}=\mathrm{C}-\mathrm{O}$ fragment of the oxazole ring. ${ }^{4}$

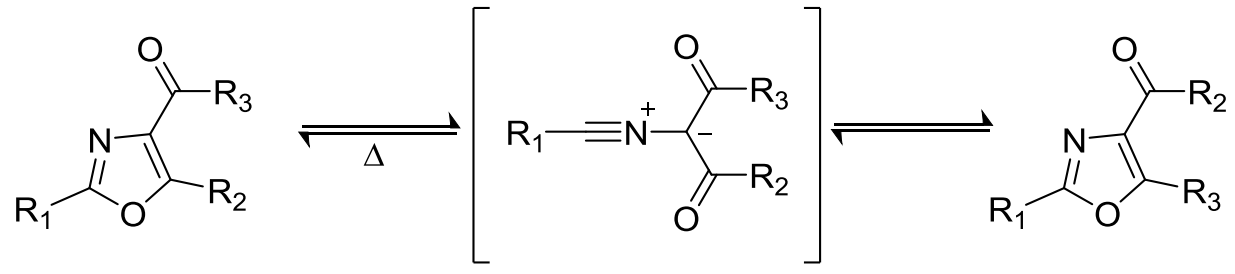

Scheme 4: Cornforth Rearrangement 


\subsection{Natural Occurring Oxazolines and Their Biological Roles}

The discovery of natural occurring oxazolines and oxazoles have stimulated significant interest in the chemistry and biology of these heterocycles. Naturally occurring oxazolines (i.e., 4, 5-dihydro2-oxazoles) which contain a secondary phenolic functionality are also known as hydroxyphenyl oxazolines (iii: Figure 1.1.1). Photobactin is a naturally occurring oxazoline compound and it is the main focus of this thesis project. The 2-(2'-hydroxyphenyl)-2-oxazoline (Hphox: iii) moiety is a common constituent found in many microbial siderophores. Siderophores are low molecular weight compounds (500-1000 Daltons) with a very high and specific binding affinity for iron (vida infra). ${ }^{5}$

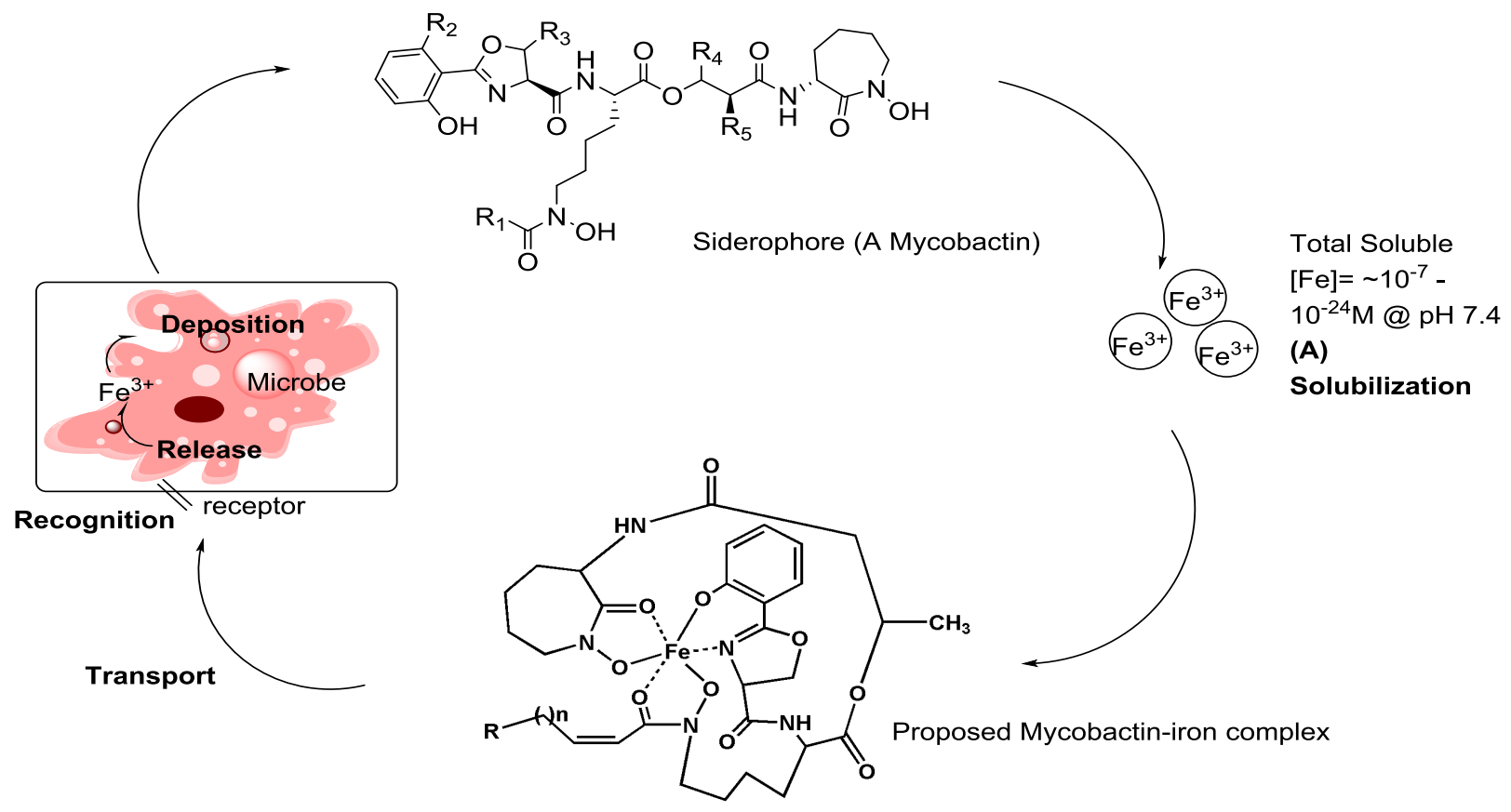

Figure 1.2.1: Siderophore mediated iron availability

Siderophores are found in microorganisms and in some plants. Microorganisms, such as bacteria, biosynthesize these compounds to selectively sequester iron from the environment. This decreases its availability for competitors while scavenging and regulating iron concentration in 
the cell (Figure 1.2.1). In addition, ferric ion at physiological $\mathrm{pH}$ is extremely insoluble, thus, siderophores have been evolved by microorganisms to solubilize it. Therefore, outside the cell, siderophores can sequester iron in its different natural forms in aqueous-aerobic conditions at $\mathrm{pH}$ 7.4: (A) $\mathrm{Fe}^{3+}(\mathrm{aq})\left(K_{s p}=2.60 \times 10^{-39}\right),[\mathrm{Fe}(\mathrm{OH})]^{2+}(\mathrm{aq})$, and $\left[\mathrm{Fe}(\mathrm{OH})_{2}\right]^{+}(\mathrm{aq})\left(K_{s p}=4.90 \times 10^{-7}\right)$. Donor atoms with a high affinity for Fe (III) include negatively charged oxygen atoms. Siderophores contain these hard $\mathrm{O}$-donor atoms as ligands and form thermodynamically very stable complexes with $\mathrm{Fe}^{3+}$. The concentration of iron in the environment of a microorganism is extremely low (between $10^{-7}$ and $10^{-24} \mathrm{M}$ ). ${ }^{6}$ Once the iron is chelated, it forms a soluble iron complex. The siderophores transport the iron to the bacteria using a specific outer-membrane receptor, a periplasmic protein, and several inner-membrane associated proteins (Figure 1.2.1) ${ }^{6}$ Once the iron is in the cell, it is removed from the siderophore, and the cycle repeats itself. Moreover, the oxidation state of iron has major influence on the stability of iron siderophore complexes. $\mathrm{Fe}^{2+}$ siderophore complexes are more liable than $\mathrm{Fe}^{3+}$ siderophore complexes. $\mathrm{Fe}^{2+}$ is a softer cation than $\mathrm{Fe}^{3+}$. The interaction to a hard oxygen of the binding ligand is therefore not as favourable. Some examples of siderophores that have a 2-hydroxyphenyl-2-oxazoline unit are: Parabactin, Agrobactin, Mycobactin S, and Transvalencin Z (Figure 1.2.2a). Siderophores that have 2,3-dihydroxyphenyl-2-oxazoline unit are: Photobactin, Vibriobactin, and Acetobactin (Figure 1.2.2b). All of the siderophores mentioned come from a different type of bacterium.

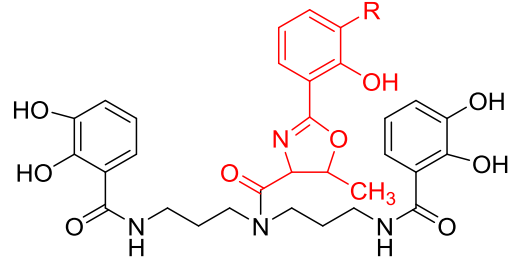

Parabactin $(\mathrm{R}=\mathrm{H})$ Agrobactin $(\mathrm{R}=\mathrm{OH})$

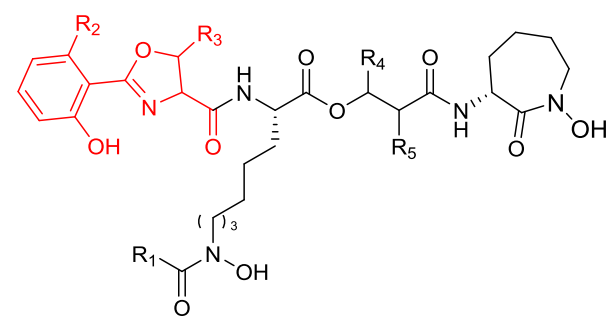

Mycobactin

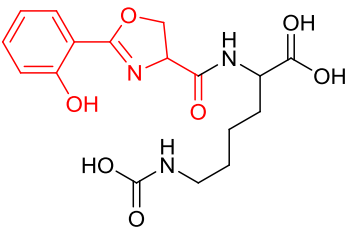

Transvalencin Z

Figure 1.2.2a: Structures of siderophores that contain the Hphox Unit 


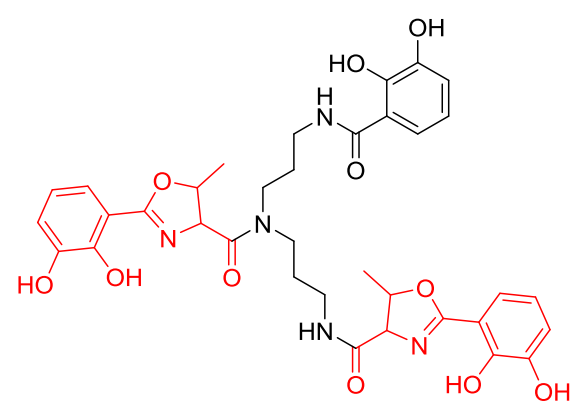

Vibriobactin

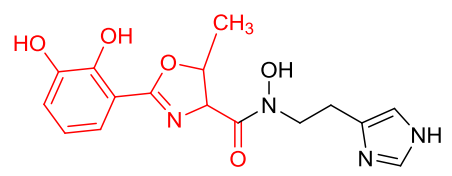

Acinetobactin

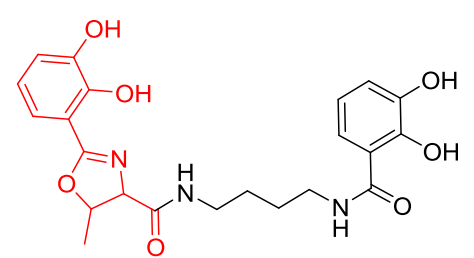

Photobactin

Figure 1.2.2b: Structures of siderophores that contain the Hphox Unit

\subsection{Siderophore Binding to Iron}

Siderophores are chelators with exceptionally strong affinity for iron and best known for their capacity to feed microorganism with ferrous and ferric ions. The binding constant $\left(\mathrm{K}_{\mathrm{Binding}}\right)$ of

$\mathrm{Fe}^{3+}+\mathrm{L} \rightleftharpoons\left[\mathrm{FeL}^{3+}\right.$
$\mathrm{K}_{\text {Binding }}>10^{30}$
$\mathrm{~K}_{\text {Binding }} \frac{[\mathrm{FeL}]^{3+}}{\left[\mathrm{Fe}^{3+}\right][\mathrm{L}]}$
$\mathrm{L}=$ Siderophore

Figure 1.3.1: Binding Constant Reaction/ Equation
$\mathrm{Fe}^{3+}$ complex is $10^{30}$ or higher (Figure 1.3.1), that means upon deprotonation of the hydroxyl groups on the Hphox moiety (iii) siderophore ligands bind strongly to the metal. ${ }^{7}$ The siderophore ligands are usually catecholate and hydroxamate or, less frequently, Hphox residues. For instance, with the Mycobactin $S$, the two hydroxamate residues and Hphox residues act in concert to form an extremely stable iron (III) complex (Figure 1.2.2a). Moreover, the hydroxyphenyl oxazoline moiety can also behave as a bidentate ligand with a metal centre coordination. ${ }^{7}$

Catecholate, carboxylate, hydroxamate, and phenolate which are incorporated into the siderophores as major groups are the most efficient Fe-binding ligands found in nature (Figure<smiles>[M]Oc1ccccc1O</smiles><smiles>[M]OCC(=O)O</smiles><smiles></smiles><smiles>[M]Oc1ccccc1</smiles>

1.3.2). ${ }^{5}$ The catecholate, carboxylate, $M=$ Transition Metal sites of the iron centre. Iron

Figure 1.3.2: Other ligand motifs common in siderophores coordinates to a lone pair of electrons 
on an oxygen atom from the siderophore ligand. As oxygen is a very hard donor atom it shows high affinity for hard Fe (III) cations. Siderophore ligands are weak acids, therefore the greater the basicity of the chelator, the greater its affinity for $\mathrm{Fe}^{3+} .5$ In aqueous solution, the formation of iron siderophore complexes is affected by the $\mathrm{pH}$. The free protons and the iron compete for the free siderophore ligand. The higher the $\mathrm{pK}_{\mathrm{a}}$ value, the stronger competition by protons. Therefore, siderophore ligands show high affinity for high oxidation state iron.

Majority of siderophores display octahedral coordination to $\mathrm{Fe}^{3+}$ where six ligands coordinate to the iron $(\mathrm{CN}=6)$, and that is because three of the oxygen donor ligands are usually incorporated into the siderophore. ${ }^{6,8}$ In Parabactin and Agrobactin, the tertiary nitrogen atom of the oxazoline contains a binding site for the six coordinate ferric ion (Figure 1.3.3). Ferric ion is known as a hard acid, so it prefers to coordinate to oxygen rather than a softer base like nitrogen. However, binding to nitrogen in Agrobactin or Parabactin places the ferric ion in a six membered ring and the environment is known to favour its stability. In addition, the stability of iron siderophore complexes is not only affected by the number and type of ligand binding sites but also by their relative arrangements to each other. $A$ preorganization of the binding sites is what keeps them in order and allows an octahedral configuration which affects the stability of the complex. However, siderophores like Photobactin and Serratiochelin (Figure 1.3.4) have only

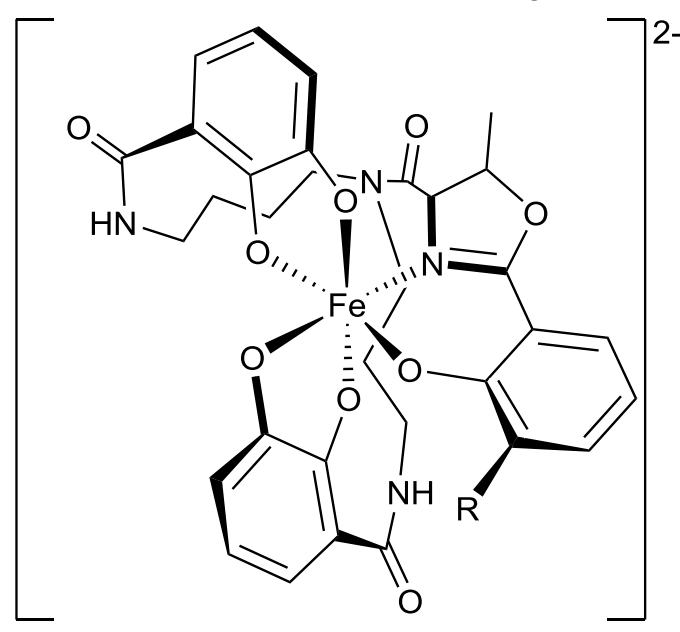

Figure 1.3.3: Ferric Agrobactin $(\mathrm{R}=\mathrm{OH})$ and Ferric Parabactin $(\mathrm{R}=\mathrm{H})$ two catechol ligands. Researchers hypothesize that Serratiochelin may be a hexadentate (6-coordinate) or tetradentate (4-coordinate) ligand. ${ }^{9}$ For it to form an octahedral, there has to be two catechols, which would give it four binding sites. Also, the nitrogen on the oxazoline, and the oxygen on the L-Threonine moiety would give two extra binding sites. ${ }^{9}$ Alternatively, it might be a tetrahedral complex with only one of the catechol (both 
$-\mathrm{OH})$ coordinating to the iron, which would give it two binding sites. The nitrogen on the oxazoline, and one hydroxyl group from the catecholate gives it the two additional binding sites. ${ }^{9}$ The reason why tertiary nitrogen on the oxazoline will be favoured over the second hydroxyl on the catechol can probably be explained by the corresponding $\mathrm{pK}_{\mathrm{a}}$ values of around 7 and 11 respectively. $6.8,9$<smiles>CC1OC(c2cccc(O)c2O)=N[C@@H]1C(=O)NCCCNC(=O)c1cccc(O)c1O</smiles>

Figure 1.3.4: The Structure of Serratiochelin

Due to the resonance effect (the partial charge) on the nitrogen atom (Figure 1.3.5), Fe-N (oxazoline) bond formation would be preferred, since oxygen is relatively electron deficient. Moreover, the type of iron coordination with Vibriobactin is debatable according to researchers, since it contains three catechol ligands and two oxazolines. Griffiths et.al, 7,10 suggested that nitrogen atom of the oxazoline / oxazole can partake in iron coordination while Miethke et.al, ${ }^{6,10}$ suggested that six oxygens from the catechol ligands would coordinate to the iron atom. Based on the holo-ViuP structure,${ }^{10}$ it discloses that Ferric-Vibriobactin complex has six binding sites from five hydroxyl groups of the catechol ligands and the last binding site comes from the nitrogen on the oxazoline. ${ }^{10} \mathrm{ViuP}$ is a periplasmic transport protein which moves FeVibriobactin complex from outer membrane to inner membrane of Vibrio cholerae. ${ }^{10}$ Holo is a protein with ligands, while Apo is a protein without ligands. Furthermore, a potential Fe-Photobactin complex

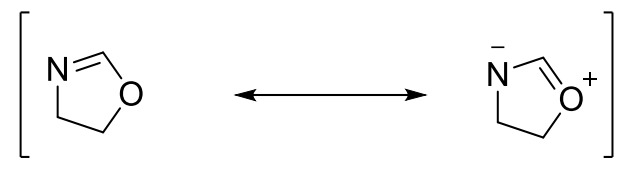

Figure 1.3.5: Resonance structure of an oxazoline could be a distorted tetrahedral or octahedral where nitrogen from the oxazoline participates as a coordinating ligand.

\subsection{Applications}

The extraordinary ability of siderophores to chelate and mobilize iron, allow there to be potential applications for siderophores in medical sciences. Iron is an important element involved in proper functioning of various physiological activities among living systems such as plants, animals, and 
human beings. Its excess and deficiency lead to numerous diseased situations, which makes siderophores suitable for applications in medicine such as, selective drug delivery, treatment of iron overload, and cancer therapy.

Siderophores can be used for selective delivery of antibiotics. This new antimicrobial approach to defeat drug resistant bacteria, uses the iron transport abilities of siderophores to take drugs into cells by means of conjugates formed between siderophores and antimicrobial agents. ${ }^{6}$ Siderophores are used as mediators to facilitate the cellular uptake of antibiotics. ${ }^{6}$ This interaction of antibiotics with siderophores results in formation of siderophore-conjugate known as siderocymins. ${ }^{6}$ The siderophore part of this conjugate is capable of hunting for iron, while the other part of the conjugate bears an antibiotic activity, which uses the siderophore as a Trojan horse and mediates iron transport mediated drug delivery into the cell. ${ }^{6}$ Additionally, the antimicrobial agents covalently linked to the siderophore are actively transported across the outer membrane of gram-negative bacteria. Generally the drug conjugate consist of a linker for attaching the drug to the siderophore. Once getting into the bacterial cell, the siderophore-drug conjugate kills the cell by releasing the drug, acting as a complete antibacterial agent, or by blocking further iron acquisition. Natural and synthetic are the two types of conjugates. ${ }^{6}$

Natural siderophore-antibiotic conjugates are ferrimycin, danomycin, and salmycin. Ferrimycin prevent gram positive bacteria by changing protein biosynthesis. ${ }^{6}$ Danomycin and salmycin prevent protein synthesis in gram positive bacteria. These are isolated from strepomycetes and actinomycetes. They apply antibacterial activity to prevent protein synthesis. Synthetic siderophore-antibiotic conjugates are prepared using antibiotics with cell permeability and reduced susceptibility to resistance mechanism (for instance secretion). ${ }^{6}$ The siderophore is bound to a powerful antibiotic such as erythromycin or a beta-lactam. 
Several siderophores are used in treatment of acute iron intoxication and chronic iron overload disease such as hemochromatosis and sickle disease. Siderophores (i.e., deferoxamine/ desferrioxamine) can be used as chelating agents which bind to iron to produce complexes that lead to formation of ferrioxamine. Ferrioxamine is a stable complex, which is eliminated through the kidney. Deferxoamine is a chelating agent used to remove excess iron from the body. This bacterial siderophore acts by binding free iron in the bloodstream and enhances its removal through urine and feces. ${ }^{6}$ Therefore, it can be used to decrease iron overload in the body.

Microbial ferric siderophore complexes may also be useful for cancer therapy. Siderophores such as dexrazoxane and desferrithiocin are used in cancer therapy. ${ }^{6}$

\subsection{Objective}

The total synthesis of Transvalencin Z (Figure 1.4.1) was the original objective for this thesis project. This siderophore is produced by a rare Nocardia species and has simply been isolated from a bacterium called Nocardia transvalensis, which was sequestered from a Japanese patient in 2006. ${ }^{11}$ Actinomycotic mycetoma are caused by Nocardia species. Actinomycotic mycetoma is a slow growing bacterium that occurs

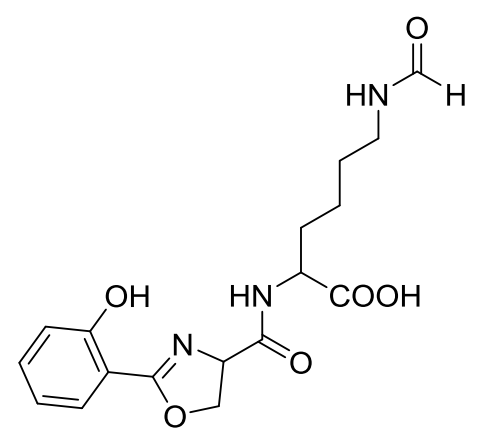

Figure 1.4.1: The structure of Transvalencin Z in one area of the body, usually the hands or feet. ${ }^{11}$ However, the total synthesis of Transvalencin $Z$ was published shortly after and this thesis project was thus revised. The intention is to focus on<smiles>CC1OC(c2cccc(O)c2O)=NC1C(=O)NCCCCNC(=O)c1cccc(O)c1O</smiles>

Figure 1.4.2: The structure of Photobactin the total synthesis of a different siderophore named Photobactin (Figure 1.4.2), and to study its binding properties with iron through Ultraviolet-visible (UV-Vis) spectroscopy and density functional theory (DFT) calculations. Photobactin is a related catechol siderophore that comes from an insect killing bacterium, Photorhabdus luminescens (Enterobacteriaceae). ${ }^{12}$ 
Members of the family Enterobacteriaceae (gram-negative bacteria) commonly produce catechol and hydroxamate siderophores such as Enterobactin and Aerobactin. Photobactin is found in the gut (innards) of roundworms also known as nematodes. This siderophore has been previously isolated $(<10 \mathrm{mg})$ and purified in order to determine if the siderophore activity is required for Photorhabdus luminescens to support the growth and reproduction of its nematode host. It has been characterized by UV-Vis, mass spectrometry, and nuclear magnetic resonance (NMR). The proposed Photobactin molecule was related to Vibriobactin and Agrobactin. Vibriobactin (Figure 1.2.2b) comes from Vibrio Cholera ${ }^{7}$ and Agrobactin (Figure 1.2.2a) comes from Agrobacterium tumefaciens. ${ }^{13,14}$ Agrobactin has a spermidine backbone and vibriobactin has a norspermidine backbone, while photobactin has a putrescine backbone. Agrobactin and Vibriobactin have one more 2,3-dihydroxybenzoic acid moiety compared to Photobactin. Upon characterization of Photobactin the IUPAC name was assigned as 2-(2,3-dihydroxyphenyl)-5-methyl-4,5-dihydrooxazole-4-carboxylic acid [4-(2,3-dihydroxybenzoylamino)butyl]amide. ${ }^{12}$ Photobactin is the generic or trivial name and will be used hereafter. 


\subsection{Synthetic Strategy}

The synthetic strategy to produce useful quantities of the title material, Photobactin, involves the coupling of two key building blocks. This method was inspired by Miller et al. who synthesized Mycobactin S, and Takeuchi et al. who synthesized Acetinobactin. Mycobactin S and Acinetobactin come from bacteria called Mycobacterium smegmatis and Acinetobacter baumanni, respectively. ${ }^{15,16}$

Scheme $\mathbf{5}$ shows the synthesis of Acinetobactin. Reaction of compound A with sodium nitrite, following with a substitution reaction with thionyl chloride yielded compound $\mathbf{B}$, which was then coupled to O-benzyl- $\mathrm{N}$-Boc-hydroxylamine in the presence of $\mathrm{NaH} .{ }^{16}$ The protecting group (Boc) on compound $\mathbf{C}$ was then removed with TFA to afford D. 2,3-Dihydroxybenzaldehyde (E) was combined with hydroxylamine hydrochloride, sodium formate, and formic acid to yield compound F. ${ }^{16}$ Reacting compound $\mathbf{F}$ with acyl chloride, methanol, and sodium carbonate produced compound $\mathbf{G}$, which was in turn mixed with L-Threonine derivative resulting in an oxazolidine $(\mathbf{H})$. Compound I was synthesized by the hydrogenolysis of $\mathbf{H}$, which cleaved the Bn protecting group. ${ }^{16}$ Product $\mathbf{D}$ was coupled with I to give the desired compound $\mathbf{J}$ (55\%). Compound $\mathbf{J}$ underwent hydrogenolysis and yielded the title material, Acinetobactin. ${ }^{16}$ 

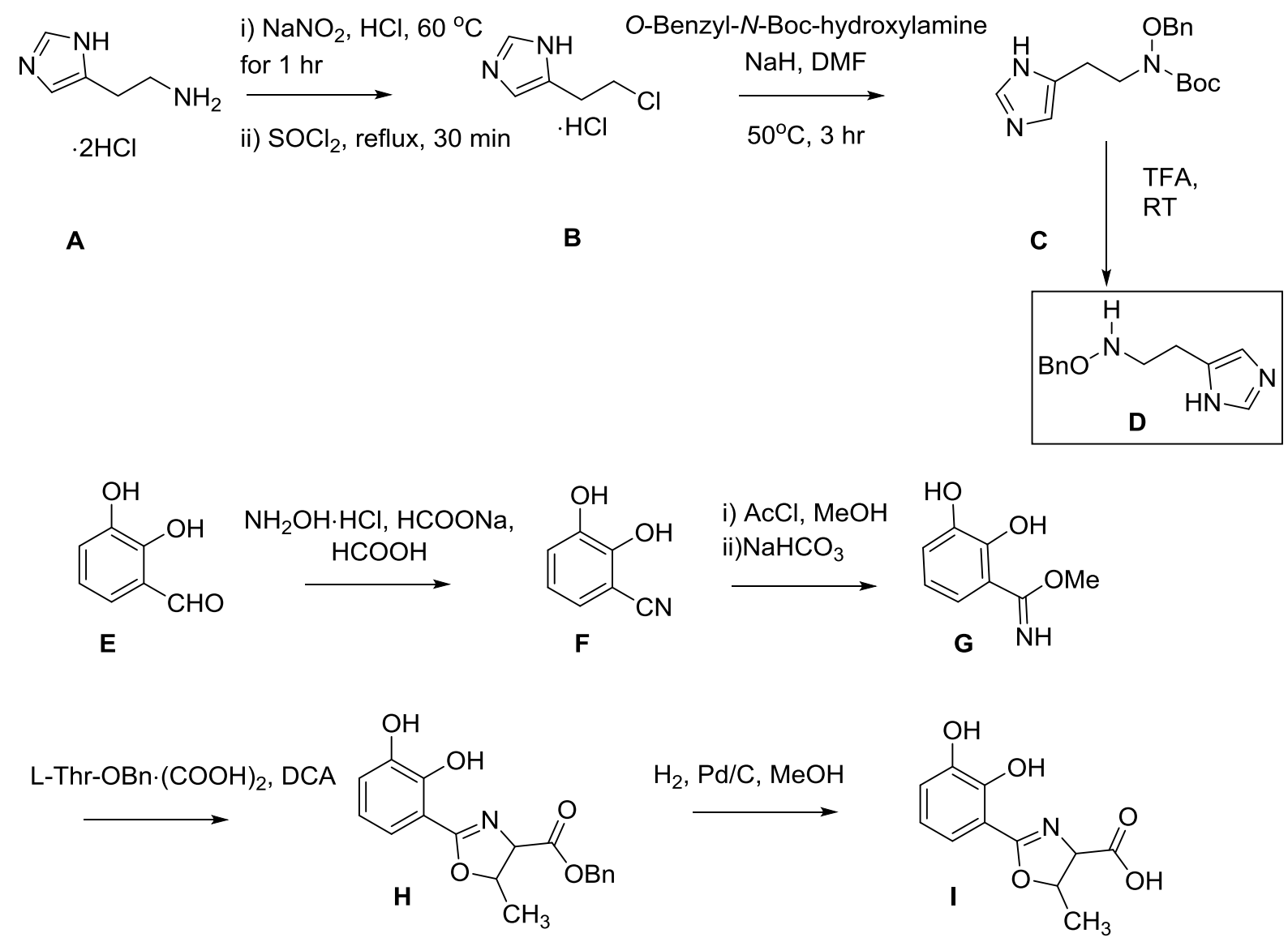

D, EDC. $\mathrm{HCl}, \mathrm{HOBt} \cdot \mathrm{H}_{2} \mathrm{O}$, DMF<smiles>CC1OC(c2cccc(O)c2O)=NC1C(=O)N(CCc1c[nH]cn1)OCc1ccccc1</smiles>

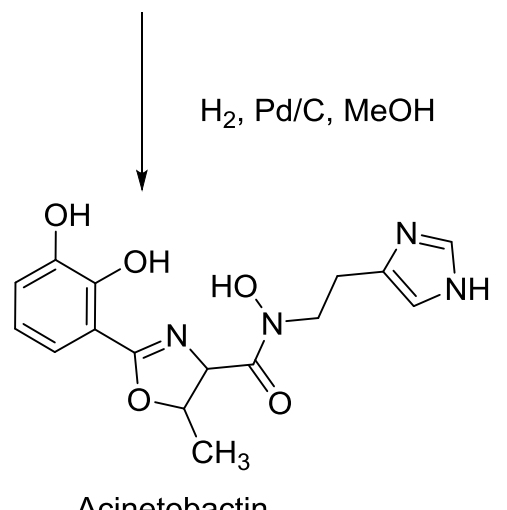

Scheme 5: Synthesis of Acinetobactin ${ }^{16}$ 
Scheme 5 also outlines a general approach to siderophore synthesis, which results in synthesizing two building blocks individually. Therefore, a multi-step procedure is required to yield the product (siderophore). As one can see in Scheme 5, nine steps is involved in order to produce Acinetobactin.

Moreover, Miller also synthesized two building blocks separately which were the protected Mycobactic acid and Cobactin T (Scheme 6). Protected Mycobactin S was obtained under Mitsunobu conditions $\left(\mathrm{PPh}_{3}, \mathrm{DEAD}\right) .{ }^{15}$ The step-by-step synthesis is not presented since it was comprised of more steps than Acinetobactin.<smiles>CCCCCCCCCCC(=O)N(CCC(NC(=O)C1COC(c2ccccc2O)=N1)C(=O)O)OC#N</smiles>

Protected mycobactic acid
Protected Cobactin T<smiles></smiles>

$\mathrm{PPh}_{3}, \mathrm{DEAD}$

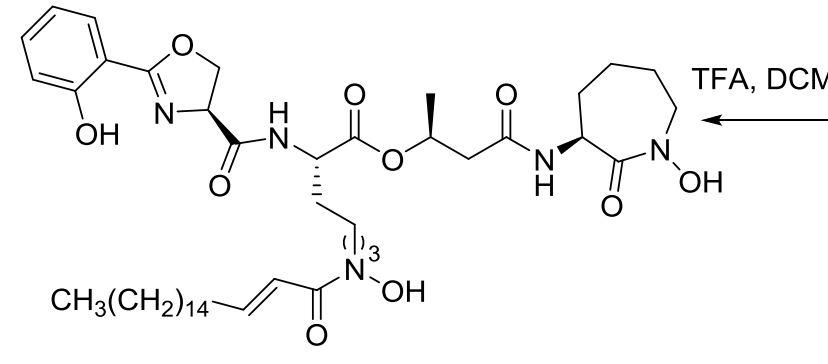

Mycobactin S

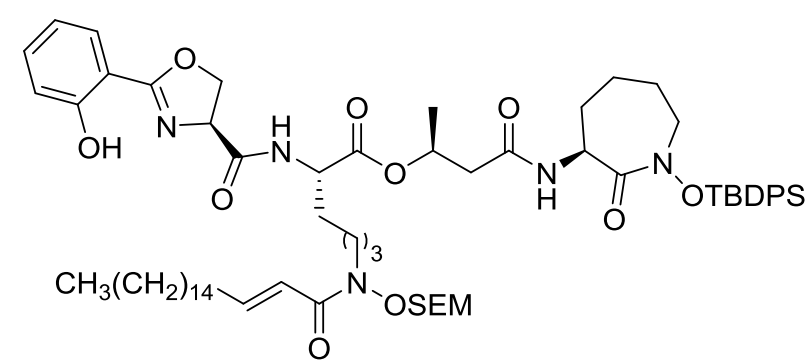

Protected Mycobactin S

Scheme 6: Synthesis of Mycobactin S from two building blocks ${ }^{15}$ 
Based on the two syntheses mentioned (Acinetobactin and Mycobactin S), the same approach is being followed to synthesize Photobactin. The oxazoline acid and the putrescine-containing building block are synthesized separately which involved Boc, methyl ester, methyl ether, benzyl ester, and benzyl ether protecting groups. Protecting groups are required for this total synthesis since certain functional groups can interfere with other reactions. The two building blocks can be combined together with a coupling reagent, following with the removal of the protecting groups (deprotection), to produce the title material, Photobactin (Scheme 7).<smiles>COc1cccc(C2=NC(C(=O)O)C(C)O2)c1OC</smiles><smiles>CC1OC(c2cccc(O)c2O)=NC1C(=O)NCCCCNC(=O)c1cccc(O)c1O</smiles><smiles>COc1cccc(C(=O)NCCCCN)c1OC</smiles><smiles>COc1cccc(C(=O)NCCCCNC(=O)C2N=C(c3cccc(OC)c3OC)OC2C)c1OC</smiles>

Scheme 7: Proposed synthesis of Photobactin-a two building block approach 


\section{Results and Discussion}

The total synthesis of Photobactin was attempted by synthesizing two building blocks separately as proposed in Scheme 7. The first building block mentioned is the oxazoline acid, while the second building block is the putrescine containing or derivative moiety. A variety of reactions were performed and certain ones were troublesome, especially the deprotection of an ester. The purification of selected compounds was sometimes tricky due to solubility issues (e.g. liquid-liquid extraction). Furthermore, the fundamental chemical reactions are introduced, and the results of the reaction outcomes, as well as the iron binding studies are discussed in this chapter.

\subsection{Synthesis of $L$-Threonine Methyl and Benzyl Ester}

The carboxylic acid group in the amino acids is usually protected during synthetic modifications of these starting materials. The reason for that, is because amino acids have multiple reactive groups therefore, the peptide synthesis must be carefully performed. An ester can serve as a protecting group of carboxylic acids to prevent the carboxyl group from reacting in some undesired manner during peptide (amide) synthesis. Hence, the carboxylic functional group on L-Threonine and L-Serine is protected with either a benzyl or methyl ester group, so that peptide (amide) synthesis undergoes smoothly in the next step.<smiles>CC(O)C(N)C(=O)O</smiles>
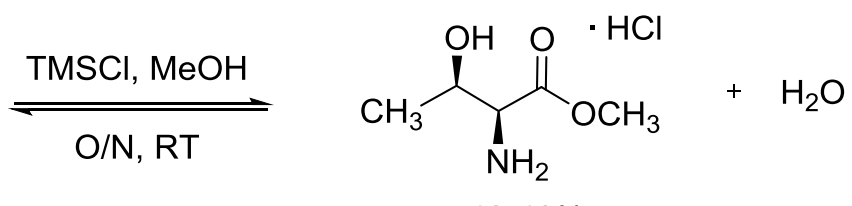

$42-48 \%$

(1)

Scheme 8: The synthesis of L-Threonine methyl ester (1) 


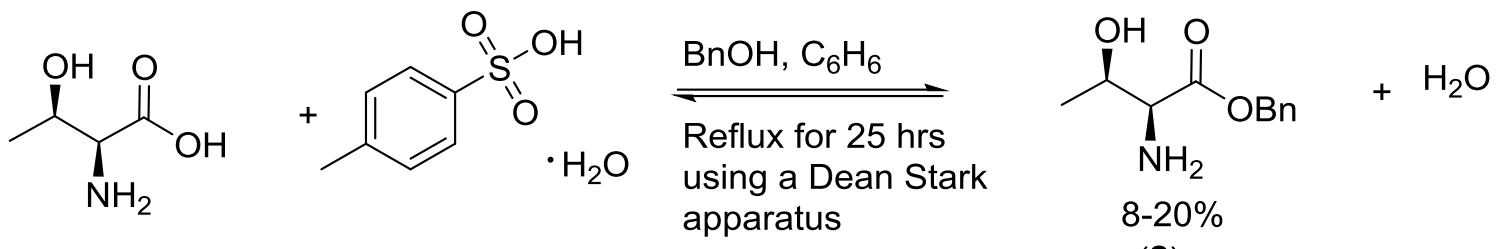

Scheme 9: The synthesis of L-Threonine benzyl ester (2)

An esterification reaction was performed in order to form an ester protecting group. Esterification using a carboxylic acid (in this case: amino acid) and an alcohol, requires an acid catalyst (e.g., trimethylsilyl chloride or p-toluenesulfonic acid monohydrate). Esterification is an equilibrium reaction, which is therefore reversible. The reaction must be shifted to the right by using excess of one reagent (methanol / benzyl alcohol) or removing one of the products (water), in order to favour the formation of the ester (Le Chatelier's Principle).${ }^{17}$ In the esterification (Scheme 9), the mixture was heated under reflux, and the benzene-water azeotrope (bp $69^{\circ} \mathrm{C}$ ) was distilled out of the flask via a Dean Stark apparatus. Water distills out of the reaction into the burette and benzene condenses back into the flask. The azeotrope, however, has to have lower boiling than the alcohol used. In methyl esterification (Scheme 8), however, methanol has a lower boiling point $\left(65^{\circ} \mathrm{C}\right)$ than the benzene-water azeotrope $\left(69^{\circ} \mathrm{C}\right)$, which means methanol would distill out of the reaction first and that would be ineffective. Therefore, a different procedure was used in Scheme 8, where it did not require a Dean Stark apparatus and/or reflux temperatures. ${ }^{17}$

\subsubsection{L-Threonine Methyl Ester Hydrochloride (1)}

L-Threonine methyl ester hydrochloride (1) was synthesized following Scheme 8. The ${ }^{1} \mathrm{H}-\mathrm{NMR}$ spectrum (Figure A1.1) showed a doublet with a chemical shift ( $\delta)$ at 1.34 ppm integrating for three protons. This was assigned to the methyl group of the $L$-Threonine moiety. The signal at $\delta$ $=3.87 \mathrm{ppm}$ corresponds to the methyl protons of the ester functional group integrating for three protons as well. The signal at $\delta=4.09 \mathrm{ppm}$ was assigned to the methine proton that is bound to the amine. It integrates for one proton. The resonance signal for the methine proton adjacent to 
the methyl and hydroxyl group was observed at $\delta=4.43 \mathrm{ppm}$ which integrates for one proton as well. The ${ }^{13} \mathrm{C}-\mathrm{NMR}$ spectrum (Figure A1.2) matches perfectly with the molecule having four carbon signals. The carbonyl carbon signal is very weak and downfield to observe, due to $\mathrm{sp}^{2}-$ hybridization and no protons attached (ipso carbon). This is typical for carbonyl carbons. ${ }^{17}$

\subsubsection{L-Threonine Benzyl Ester (2)}

Compound 2 was synthesized following Scheme 9, which was based on the literature reported by S. Pétursson and J. Baldwin. ${ }^{18}$ However, purification of the crude product was done by flash chromatography and not recrystallized as reported in the literature. ${ }^{18}$

${ }^{1} \mathrm{H}-\mathrm{NMR}$ data (Figure A1.3) was consistent with that previously reported by Pétursson and Baldwin. ${ }^{18}$ The ${ }^{13} \mathrm{C}-\mathrm{NMR}$ spectrum (Figure A1.4) showed a signal at $\delta=19.79 \mathrm{ppm}$ which was assigned to the methyl carbon of the $L$-Threonine-derived moiety. The signal at $\delta=59.93 \mathrm{ppm}$ corresponds to the carbon atom attached to the amine. The $-\mathrm{CH}_{2}$ from the benzyl functional group was observed at $\delta=65.42 \mathrm{ppm}$. The signal at $\delta=68.11 \mathrm{ppm}$ was assigned to the carbon atom of the L-Threonine moiety bound to the hydroxyl group and the methyl group. The aromatic carbons of the benzyl functional group were observed at $\delta_{C}=127.00,127.65,127.69$, and 128.59 ppm. The resonance at $\delta=140.87$ ppm was assigned to the carbonyl carbon of the molecule.

The percent yield was low. The loss of product was probably due to the liquid-liquid extraction, the reaction did not go to completion, and/or not all of the water was collected in the Dean Stark apparatus. Aqueous layer may need to be washed an additional time to recover more of the LThreonine benzyl ester. 


\subsection{Synthesis of an Amide}

Amide is a derivative of a carboxylic acid in which the hydroxyl group has been replaced by an amine group. Amide bond (peptide bond) formation was prepared in two ways (Scheme 10): via an acyl chloride and using a carbodiimides coupling reagent $(\mathrm{EDC} \cdot \mathrm{HCl})$. Acyl chlorides ${ }^{19}$ are usually produced from the corresponding acids that require either thionyl chloride, oxalyl chloride, phosphorus pentachloride or phosphorous trichloride. $N$-(3-dimethylaminopropyl)- $N$ -<smiles>CCN=C=NCCCN(C)C</smiles>

Figure 2.2.1: The structure of EDC. $\mathrm{HCl}$ ethylcarbodiimide hydrochloride (EDC. $\mathrm{HCl}$; Figure 2.2.1) is a coupling reagent that is commonly used for amide formation since it is a one-pot procedure. ${ }^{19}$ Nonetheless, urea is the by-product whereas using thionyl chloride has $\mathrm{SO}_{2}(g)$ and triethylamine hydrochloride as the by-products.<smiles>[R]OC(=O)C(N)C(C)O</smiles>

$\mathrm{R}=\mathrm{Me}(1)$ $\mathrm{R}=\mathrm{Bn}(\mathbf{2})$<smiles>COc1cccc(C(=O)O)c1OC</smiles>

OMe

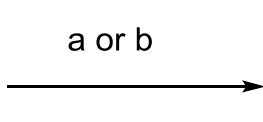<smiles>[R]OC(=O)C(NC(=O)c1cccc(OC)c1OC)[C@@H](C)O</smiles>

$\mathrm{R}=\mathrm{Me}(3)$ $\mathrm{R}=\mathrm{Bn}(4)$

Scheme 10: a. (i) $\mathrm{Et}_{3} \mathrm{~N}, \mathrm{DCM}, \mathrm{SOCl}_{2}, 0^{\circ} \mathrm{C}, \mathrm{N}_{2}, 30 \mathrm{~min}$ (ii) L-Threonine benzyl/methyl ester, overnight (O/N), RT, $\mathrm{N}_{2}$ b. DCM, HOBt, $\mathrm{Et}_{3} \mathrm{~N}, \mathrm{EDC} \cdot \mathrm{HCl}, \mathrm{RT}, \mathrm{O} / \mathrm{N}, \mathrm{N}_{2}$

Based on these two methods, the amide was isolated easily through the use of the acyl chloride which gave a better yield than when using the EDC $\cdot \mathrm{HCl}$ coupling reagent.

\subsubsection{N-(o,m)-Dimethoxybenzoyl-L-Threonine methyl ester (3)}

Method (a), shown in Scheme 10, depicts an approach taken to synthesize the methyl ester amide from the compound (1). ${ }^{1} \mathrm{H}$ and ${ }^{13} \mathrm{C}-\mathrm{NMR}$ chemical shift values were consistent with data reported by Sakakura et al. (Figure A1.5 and A1.6). ${ }^{20}$ The percent yield was low (29\%) and the loss of product is presumably during the purification step (flash column chromatography). 
2.2.2 N-(o, m)-Dimethoxybenzoyl-L-Threonine benzyl ester (4)

$N-(o, m)$-Dimethoxybenzoyl-L-threonine benzyl ester (4) was synthesized using two different approaches: acyl chloride and by EDC $\cdot \mathrm{HCl}$ coupling reagent (Scheme 10 (a) and (b)) which was based on the literature reported by Miller..$^{15}$ The impurities and by-products were removed by extraction and flash column chromatography. The acyl chloride method afforded the amide product as yellowish-brown coloured solid in a $55 \%$ yield, while EDC. $\mathrm{HCl}$ method gave only a $33 \%$ isolated yield.

The ${ }^{1} \mathrm{H}-\mathrm{NMR}$ spectrum of compound 4 (Figure A1.7) showed a singlet with a chemical shift $(\delta)$ at $3.91 \mathrm{ppm}$ integrating for six protons. This was assigned to the methyl protons of the methoxy group. A quartet of doublets was seen at $\delta=4.43 \mathrm{ppm}$ and doublet of doublets was seen at $\delta=$ $4.88 \mathrm{ppm}$ both integrating for one proton each. These were assigned to the protons of the methine adjacent to the amide nitrogen. The singlet observed at $\delta=5.23 \mathrm{ppm}$ corresponds to the protons on the $-\mathrm{CH}_{2}$ on the benzyl moiety, which integrates for two protons. The two doublet of doublets observed at $\delta=7.07 \mathrm{ppm}, 7.71 \mathrm{ppm}$, the triplet and multiplet observed at $\delta=7.18 \mathrm{ppm}$ and 7.32 $-7.35 \mathrm{ppm}$ corresponds to the aromatic protons of the benzyl and 2,3-dimethoxy benzoic acid moiety. The ${ }^{13} \mathrm{C}-\mathrm{NMR}$ (Figure A1.8) showed signal at $\delta=20.11 \mathrm{ppm}$ which was assigned to the carbon atom of the methyl group. The signals at $\delta=56.14$ and $57.90 \mathrm{ppm}$ were assigned to the carbon atoms of the methoxy groups. The peaks observed $\delta=61.64$ and $68.27 \mathrm{ppm}$ corresponds to the $-\mathrm{CH}$ groups on the amide. The $-\mathrm{CH}_{2}$ from the benzyl functional group was observed at $\delta=$ $67.26 \mathrm{ppm}$. Six unsubstituted aromatic carbons were observed. The signal at $\delta=128.62 \mathrm{ppm}$ was assigned to the ipso carbon of the aromatic ring attached to the carbonyl group. The signal at $\delta=135.36 \mathrm{ppm}$ was assigned to the ipso carbon of the aromatic ring from the benzyl functional group $(\mathrm{Bn})$. The signals at $\delta=148.06$ and $152.75 \mathrm{ppm}$ were assigned to the aromatic carbons that were bound to the carbon atoms of the methoxy groups. The signals at $\delta=165.70$ and 171.01 ppm were assigned to the carbonyl carbons of the molecule. These appear less intense than the 
other carbon signals in the molecule, which was expected for carbonyl carbons. In addition, the ${ }^{1} \mathrm{H}-\mathrm{NMR}$ for the EDC.HCl method was consistent with the data recorded for the acyl chloride method.

2.3 Synthesis of an Oxazoline
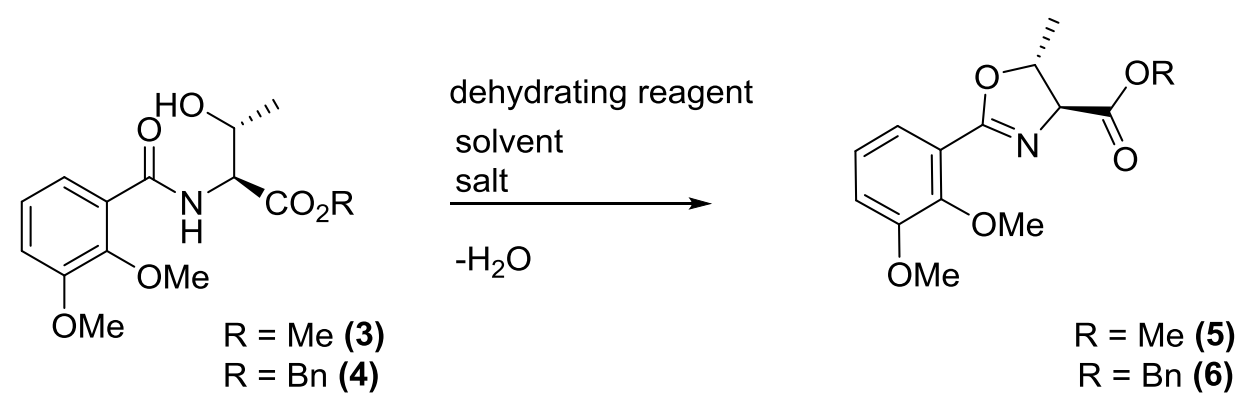

Scheme 11: The synthesis of an oxazoline

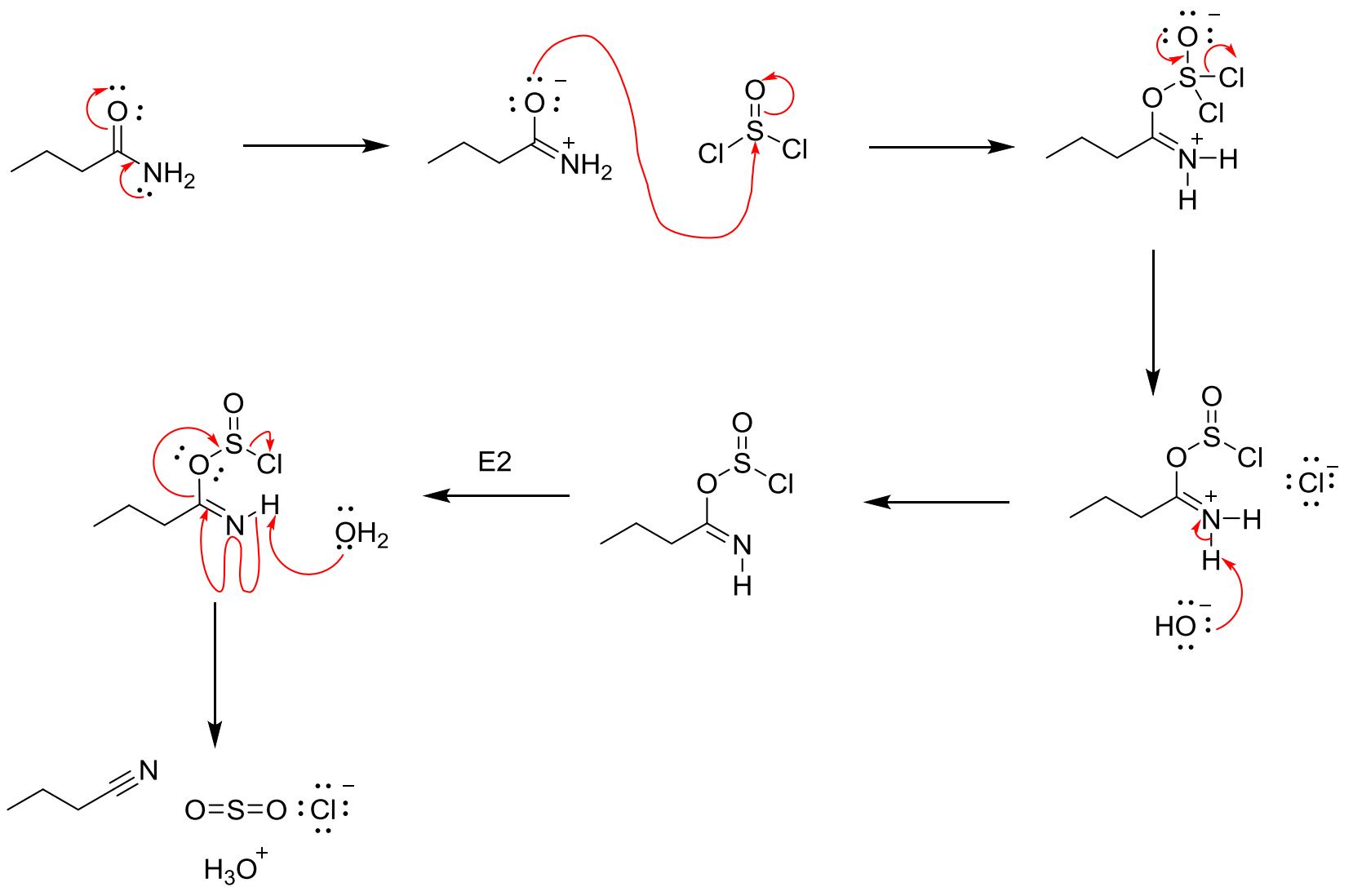

Scheme 12 : The mechanism of an amide to a nitrile by an E2 elimination 
Methyl $\mathrm{N}$-(triethylammoniumsulfonyl) carbamate, also known as the Burgess reagent, was discovered in 1968 by E. M. Burgess. It is a mild and selective dehydrating reagent often used in organic chemistry. ${ }^{21}$ This reagent is used in the dehydration of alcohols, preparation of nitriles from primary amides, and in the synthesis of heterocyclic compounds.

Thionyl chloride is an inorganic compound which is highly reactive. This reagent is used in chlorination reaction and can ease various chemical transformations. It converts alcohols to alkyl chlorides and can produce nitriles from amides through E2 elimination mechanism. ${ }^{22}$ The base (e.g. $\mathrm{H}_{2} \mathrm{O}$ ) attacks the hydrogen (from the $\mathrm{N}-\mathrm{H}$ amide bond). The $\mathrm{N}-\mathrm{H}$ bond breaks and a new $\mathrm{m}$ bond is formed on the double bond $(\pi, \sigma)$ making it form a triple bond $(2 \pi, 1 \sigma)$. However, this can only occur, when the leaving group (LG) leaves. The LG in this case in order to form the nitrile is $\mathrm{O}-\mathrm{S}=\mathrm{O}-\mathrm{Cl}$, that leaves as sulfur dioxide gas $\left(\mathrm{SO}_{2}\right)$ which drives the reaction forward. This all takes place in one step, just like $\mathrm{S}_{\mathrm{N} 2}$ reactions (Scheme 12).

Table 1: Different methods used to synthesize oxazoline

\begin{tabular}{|c|c|c|c|}
\hline & Method \#1 & Method \#2 & Method \#3 \\
\hline Dehydrating & Burgess reagent & $\mathrm{SOCl}_{2}$ & Methyl DAST \\
\hline \multicolumn{4}{|l|}{ reagent } \\
\hline Solvent & THF & Neat $\backslash \mathrm{DCM}$ & DCM \\
\hline Salt & - & - & $\mathrm{K}_{2} \mathrm{CO}_{3}$ \\
\hline Conditions & $\begin{array}{c}\text { Refluxed for } 30 \mathrm{~min}, 12 \mathrm{hrs}, 24 \\
\text { hrs }\end{array}$ & $\begin{array}{l}\text { Heated for } 30 \text { min at } \\
\qquad 45^{\circ} \mathrm{C}\end{array}$ & Stirred for $1 \mathrm{hr}$ at $-78^{\circ} \mathrm{C}$ \\
\hline Yield & $0 \%$ & $12-14 \%$ & $46 \%-99 \%$ \\
\hline
\end{tabular}


Methyl DAST (dimethylamino)sulfur trifluoride is a dehydrating reagent which has been used for the cyclodehydration of $\beta$-hydroxy amides to yield oxazolines (Scheme 13). ${ }^{23}$

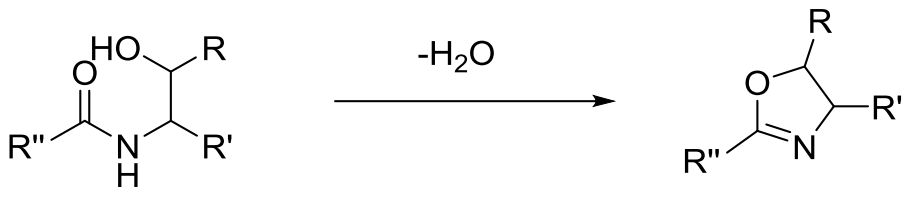

Scheme 13: Cyclodehydration of $\beta$-hydroxy amide to oxazoline

Out of the three dehydrating reagents, Methyl DAST gave the best yield of the product (Table 1). The Burgess reagent only gave the starting material (3), (4) after extended reaction times (up to 24 hours). This method failed, but worked well when $L$ - Serine methyl/benzyl ester hydrochlorides were used. The reason for that could be the Burgess reagent is milder than the other two reagents. The thionyl chloride worked, but provided a low yield of the desired oxazoline. This is due to racemization that takes place on the oxazoline ring. Therefore, Methyl DAST was the main reagent used for preparing oxazolines from amides (Scheme 11: Table 1: method 3).

\subsection{1 ((4S, 5R)-2-(o, m)-Dimethoxyphenyl)-5-methyl-4-oxazolinecarboxylic acid methyl ester (5)}

Compound 5 was a colourless solid with a $46 \%$ yield after extraction and purification using flash column chromatography. ${ }^{1} \mathrm{H}$ and ${ }^{13} \mathrm{C}-\mathrm{NMR}$ chemical shift values were identical to the reported values stated by Sakakura et al. (Figure A1.9 and A1.10). ${ }^{20}$

$$
\mathrm{R}=\mathrm{H}, \mathrm{Me}, \mathrm{Bn}, \mathrm{o}-\mathrm{xyl}
$$<smiles>CC(=O)[C@H](NC(=O)c1cccc2c1O[R]O2)[C@@H](C)O</smiles>

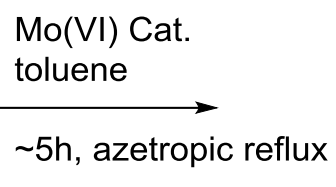<smiles>CC(=O)[C@H]1N=C(c2cccc3c2O[R]O3)O[C@@H]1C</smiles>

Scheme 14: $\mathrm{Mo}(\mathrm{VI})=\mathrm{O}$ catalyst used to synthesize an oxazoline.$^{20}$

The method they used required Molybdenum (VI) oxide as a dehydrative cyclization catalyst which is shown in Scheme $\mathbf{1 4}^{20}$, whereas Method 3 from Table 1 was used instead. The molybdenum (VI) oxide was attempted twice but failed both times. This could be due to the fact 
the Soxhlet extractor, as well as dry solvents and inert atmosphere were required. Methyl DAST however, was easier to use, the method was simple, and gave higher yields.

\subsection{2 ((4S,5R)-2-(o,m)-Dimethoxyphenyl)-5-methyl-4-oxazolinecarboxylic acid benzyl ester (6)}

Method 3 (Table 1) was used to synthesize (4S,5R)-2-(o,m)-Dimethoxyphenyl)-5-methyl-4oxazolinecarboxylic acid benzyl ester (6). The by-products were removed by liquid-liquid extractions and the product was purified by flash column chromatography. This afforded the title product as a colourless oil in yields between $84 \%$ and $100 \%$.

The ${ }^{1} \mathrm{H}-\mathrm{NMR}$ spectrum (Figure A1.11) showed a doublet with a chemical shift (ס) $1.33 \mathrm{ppm}$ integrating for three protons. This chemical shift was assigned to the methyl group on the oxazoline. The two singlets at $\delta=3.86$ and $3.87 \mathrm{ppm}$ integrating for three protons each were assigned to the methyl protons of the methoxy group. The signal at $\delta=4.99-5.04 \mathrm{ppm}$ integrated for two protons, this was assigned to the protons on the oxazoline ring (the - $\mathrm{CHs}$ ). The singlet at $\delta=5.22 \mathrm{ppm}$ was assigned to the $-\mathrm{CH}_{2}$ of the benzyl functional group which integrated for two protons. The peaks observed at $\delta=7.02$ to 7.09 and 7.32 to $7.37 \mathrm{ppm}$ were aromatic protons since they appeared in the aromatic region of the spectrum. The ${ }^{13} \mathrm{C}-\mathrm{NMR}$ (Figure A1.12) showed signal at $\delta=16.10 \mathrm{ppm}$ corresponding to the carbon atom of the methyl group that was bound to the oxazoline ring. The resonance signals observed at $\delta=56.18$ and $61.50 \mathrm{ppm}$ were assigned to the methoxy carbons. The signal of the benzyl $-\mathrm{CH}_{2}$ carbon was seen at $\delta=66.94 \mathrm{ppm}$. The signals at $\delta=71.67$ and $77.55 \mathrm{ppm}$ were assigned to the carbon atoms of the $-\mathrm{CHs}$ on the oxazoline ring. The signals at $\delta_{C}=115.58,122.44,122.68,123.87,128.50$, and $128.59 \mathrm{ppm}$ were assigned to the aromatic carbons. The signals at $\delta=128.73 \mathrm{ppm}$ was assigned to the aromatic carbon that was bound to the carbon atom of the oxazoline moiety. The signal at $\delta=135.33 \mathrm{ppm}$ corresponds to the aromatic carbon of the benzyl functional group that was attached to the $-\mathrm{CH}_{2}$. The peaks observed at $\delta=148.92$ and $153.42 \mathrm{ppm}$ are assigned to the aromatic carbons that are bound to the methoxy functional groups. The signal at $\delta=165.41 \mathrm{ppm}$ correspond to the carbon 
atom on the oxazoline attached to the nitrogen atom. Double bond and triple bond carbon atoms generally appear more downfield than single bonded carbon atoms. The last signal was at $\delta=$ 169.79 ppm and that appeared as a carbonyl carbon of the ester functional group.

On the other hand, the compounds $\mathbf{5}$ and $\mathbf{6}$ were not stable for extended periods, they tend to ring open after two weeks in air. They are therefore usually sealed and stored in the fridge $\left(-10^{\circ}\right.$ C to $\left.-20^{\circ} \mathrm{C}\right)$.

\subsection{Deprotection of the Ester protecting group}

Deprotection of the carboxylic acid usually involves saponification (under basic conditions). Bulky esters like benzyl esters may or may not be able to cleave under basic conditions, so they are generally removed by catalytic hydrogenation. That being said, simple methyl esters are regularly

cleaved by base catalyzed hydrolysis using alkali metal hydroxides (e.g. $\mathrm{NaOH}, \mathrm{LiOH}$ ) in aqueous methanol or THF. In more complex compounds, it is suggested to use LiOH in a mixture of THF$\mathrm{H}_{2} \mathrm{O}$ or $\mathrm{MeOH}$. Benzyl esters on the other hand are regularly cleaved under reductive conditions using anhydrous methanol with activated palladium on carbon and $\mathrm{H}_{2}(g)$. Therefore, deprotections are simple reactions, but the reason why deprotection is challenging is because some substrates and compounds are not compatible with the deprotection methods used. Scheme 15 displays the reaction of the deprotection of compounds 5 and $\mathbf{6}$ from the first building blocks; Table 2 and Table 3 show the various methods and conditions taken to attempt the deprotection. ${ }^{17}$ 
<smiles>COC(=O)C1N=C(c2cccc(OC)c2OC)OC1C</smiles>

(5)<smiles>COc1cccc(C2=NC(C(=O)OCc3ccccc3)C(C)O2)c1OC</smiles>

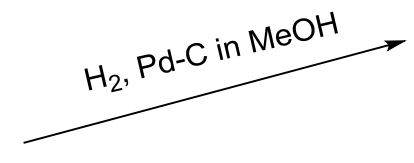<smiles>COc1ccc(O)cc1</smiles><smiles>COc1cccc(C2=NC(C(=O)O)C(C)O2)c1OC</smiles>

(7)

Scheme 15 : Deprotection of methyl and benzyl ester from the $1^{\text {st }}$ building bbock

From the series of attempts, the deprotection was unsuccessful for both $\mathbf{5}$ and $\mathbf{6}$. Methyl ester compounds are stable compounds and are trouble-free protecting groups. Vigorous treatment is required in deprotection due to their high stability. Saponification is sometimes satisfactory but even when it is carried out under carefully controlled optimized conditions as the methods shown in Table 2, the alkali metals can cause side reactions or racemization. This is why when ${ }^{1} \mathrm{H}-\mathrm{NMR}$ was performed for those reactions, each one resulted

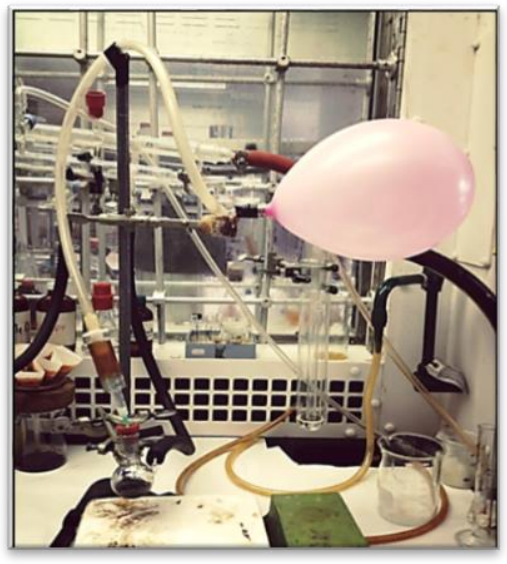

Figure 2.4.1: Deprotection of $\mathrm{Bn}$ Ester using a balloon filled with $\mathrm{H}_{2}$ in an unsuitable spectrum. The peaks were not resolved properly, it was difficult to say if a peak was a doublet or triplet because they all appeared as broad singlets. The aqueous layer of (7) from (5) was also checked because if the deprotection was successful, the compound becomes more polar which means more soluble in water than ethyl acetate. However, when spotted on TLC plate, no spot was shown under the UV lamp. Compound 7 would be UV active because there is an aromatic ring. The conditions were then altered by using different concentrations of $\mathrm{HCl}$, where it was used to acidify the aqueous layer in order to protonate the oxygen. Additionally, the reactions for both Methods 1 and 2 went for a longer period of time and were monitored by 
TLC (Table 2). Method $2^{24}$ was followed by a literature procedure by S. Banala et al. but the method was ineffective. Both methods were unsuccessful even when the conditions were modified.

Table 2: Attempts of deprotection of methyl ester using different methods

\begin{tabular}{|c|c|c|c|c|c|}
\hline Method & Attempts & Solvent & Condition & Time & Product \\
\hline 1 & 4 & $\mathrm{MeOH}$ & $\begin{array}{l}\text { Methyl ester (5) in } 1 \mathrm{~mL} \mathrm{MeOH} \text { and } 1 \mathrm{~mL} \text { of } \\
0.5 \mathrm{~N} \mathrm{NaOH} \text {. This was stirred (monitored by } \\
T L C) \text {. Then add } 1 \mathrm{~mL} \text { of water and extract } \\
\text { with } \mathrm{Et}_{2} \mathrm{O} \text {. Aqueous layer was acidified to } \\
\mathrm{pH}=2 \text { with } \mathrm{HCl}(6 \mathrm{~N}, 1 \mathrm{M}, 0.5 \mathrm{~N}) \text { and extracted } \\
\text { with EtOAc. }\end{array}$ & $5 \mathrm{~min}-2 \mathrm{hrs}$ & $\mathrm{NO}$ \\
\hline 2 & 2 & THF- $\mathrm{H}_{2} \mathrm{O}$ & $\begin{array}{l}1 \text { eq of methyl ester (5) in } 10 \mathrm{~mL} \text { THF and } \\
\mathrm{H}_{2} \mathrm{O}(5 \mathrm{~mL}) \text { and } 2 \text { eq } \mathrm{LiOH} \cdot \mathrm{H}_{2} \mathrm{O} \text { were } \\
\text { added. Reaction stirred at } \mathrm{RT} \text {. Then THF } \\
\text { was removed. Aqueous layer was acidified } \\
\text { to } \mathrm{pH} 2 \text { with } 5 \% \mathrm{HCl} \text { and extracted with } \\
\text { EtOAc. Then the organic layer concentrated } \\
\text { in vacuo. }\end{array}$ & $1 \mathrm{hr}-2 \mathrm{hrs}$ & $\mathrm{NO}$ \\
\hline
\end{tabular}

Table 3: Attempts of deprotection of benzyl ester using different methods

\begin{tabular}{|c|c|c|c|c|c|}
\hline Method & Attempt & Solvent & Condition & Time & Product \\
\hline 1 & 8 & $\mathrm{MeOH}$ & $\begin{array}{l}\text { For every } 0.1 \mathrm{mmol} \text { of } \mathrm{Bn} \text { ester (6) add } 10 \mathrm{mg} \\
\text { of } \mathrm{Pd} / \mathrm{C} \text { and } 1 \mathrm{~mL} \text { of } \mathrm{MeOH} \text { with } \mathrm{H}_{2} \text { bubbling } \\
\text { through the solution (balloon/directly from } \\
\text { tank). Once it was complete (monitored by } \\
T L C \text { ). The mixture was filtered through celite } \\
\text { and concentrated in vacuo. }\end{array}$ & $1-6$ hrs. & NO \\
\hline 2 & 3 & ACN & $\begin{array}{l}0.5 \mathrm{~mL} \text { of } \mathrm{ACN} \text { in } 10 \mathrm{mg} \text { of } \mathrm{Bn} \text { ester (6). Add } 1 \\
\mathrm{~mL} \text { of } 1 \mathrm{M} \mathrm{LiOH} \text { and stir at } \mathrm{RT} \text { (monitoring by } \\
T L C \text { ). Add } 1 \mathrm{~mL} \text { of water and extract with } \mathrm{Et}_{2} \mathrm{O} \text {. } \\
\text { To the aqueous solution add buffer } 4 \text { solution } \\
\text { till the reaction is } \mathrm{pH} 4 \text {. Then extract with } \\
\text { EtOAc, and the organic layer is left to } \\
\text { evaporate. }\end{array}$ & $30 \mathrm{~min}-2 \mathrm{hrs}$ & NO \\
\hline
\end{tabular}


Removing the benzyl ester from (6) was challenging. It was expected that the benzyl ester could be easily cleaved by catalytic hydrogenolysis. However, the reaction failed more than once, as can be shown in Table 3. The reason for that could be due to short reaction time at $1 \mathrm{~atm}$, the reaction needed to be under a higher pressure ( $>1 \mathrm{~atm}$ ), and/ or the slight impurities in compound 6 can interfere with the deprotection.

A balloon was first filled with $\mathrm{H}_{2}(g)$ since there was less than 200 milligrams of the compound (Figure 2.4.1). After a couple of trials, $\mathrm{H}_{2}(g)$ was then bubbled directly through the mixture. However, the regulator on the hydrogen tank was not functioning properly since $\mathrm{H}_{2}(g)$ was constantly bubbling on and off throughout the reaction. From ${ }^{1} \mathrm{H}-\mathrm{NMR}$, the benzyl group did not cleave. As this method was causing difficulties, it was decided to do it under basic conditions analogous to the deprotection of the methyl ester but instead a buffer ( $\mathrm{pH} 4)$ is used (Table 3: Method 2). The buffer is used to allow the aqueous layer to not reach a $\mathrm{pH} 2$, as it can be too acidic; oxazolines are sensitive to acid. Therefore, the phosphate buffer $(\mathrm{pH} 4)$ was prepared with $1 \mathrm{M}$ trisodium phosphate and phosphoric acid. Therefore, the deprotection of the ester from the first building block has been unsuccessful, which has prevented the synthesis of Photobactin.

\subsection{Synthesis of the Benzamide: Part I}

The most common protecting groups for amines are carbamates such as $\mathrm{Cbz}$, Boc, and F-moc (Figure 2.5.1). Boc (i.e., tert-butoxycarbonyl) is widely used in synthetic organic chemistry for<smiles>[R]C([R20])OCc1ccccc1</smiles>
$\mathrm{Cbz}$

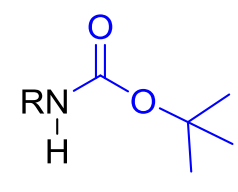

Boc<smiles>[R]NC(=O)OCC1c2ccccc2-c2ccccc21</smiles>

F-moc protecting $\mathrm{NH}_{2}$ groups and it is unreactive to most bases and nucleophiles. This protecting

Figure 2.5.1: Common protecting groups for amines group is used in this thesis project as one of the ways to synthesize the second building block. If Boc group was not used, side reactions, such as forming dimers can happen. N,N'-Bis(2,3-bis(methoxy)benzoyl)-1,4diaminobutane can be formed because 1,4-diaminobutane is a symmetrical compound as a result 
the amine group is identical on both sides of the molecule. This means both amines on the compound will attack the electrophile, which is why Boc protecting group are generally added to the amine (on one side) using di-tert-butyl dicarbonate $\left(\mathrm{Boc}_{2} \mathrm{O}\right)$, shown in Scheme 16.

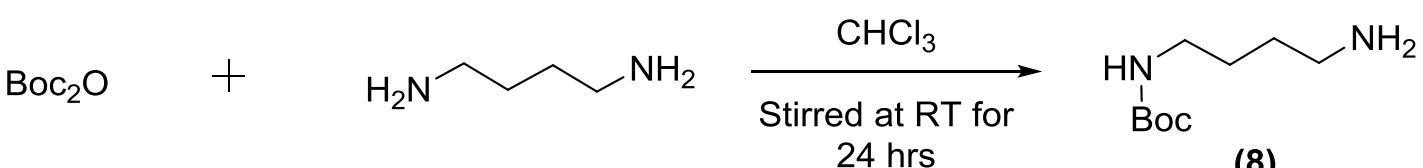

Scheme 16: Synthesis of Boc-1,4-diaminobutane (8)

The reaction in Scheme $\mathbf{1 7}$ is straightforward and is a one pot synthesis. This reaction forms a benzamide compound as the product by using carbodiimide coupling reagent - EDC $\cdot \mathrm{HCl}$.

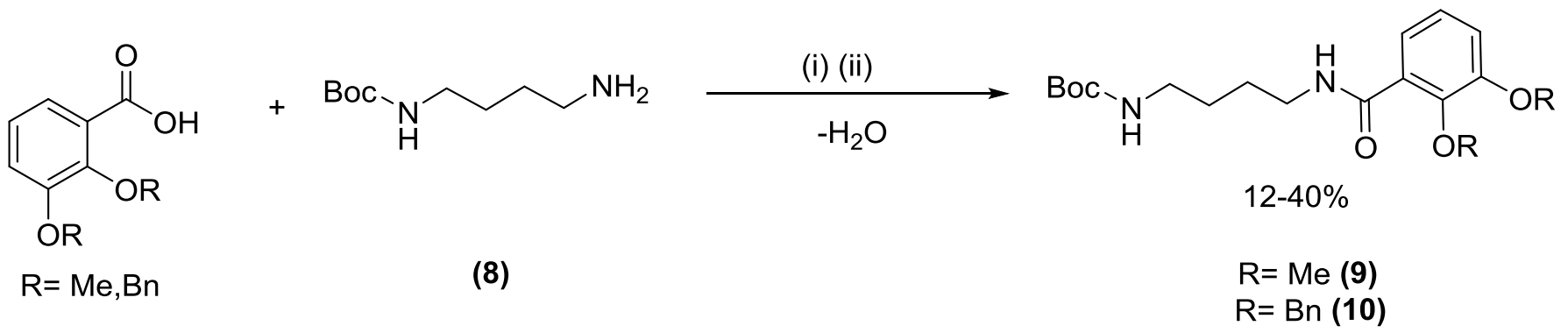

Scheme 17: (i) DCM, HOBt, $\mathrm{Et}_{3} \mathrm{~N}$, EDC. $\mathrm{HCl}$ (ii) stirred $\mathrm{O} / \mathrm{N}$, under $\mathrm{N}_{2}, \mathrm{RT}, 12-40 \%$

\subsubsection{Boc-1,4-diaminobutane (8)}

The compound was a pale yellow coloured thick liquid isolated after gravity filtration similar to the commercially available one bought from Sigma Aldrich. ${ }^{1} \mathrm{H}-\mathrm{NMR}$ chemical shift values were analogous to the reported values stated in the Spectral Database of Organic (Figure A1.13). ${ }^{25}$

\subsubsection{N-Boc (1,4-aminobutyl)-2,3-(dimethoxyphenyl) benzamide (9)}

$N$-Boc (1,4-aminobutyl)-2,3-(dimethoxyphenyl) benzamide (9) was synthesized by an amide coupling reagent $\mathrm{EDC} \cdot \mathrm{HCl}$ (Scheme 17). The impurities and by-products were removed by extraction and flash column chromatography. This method gave a $25 \%$ yield of the target compound after purification as a yellow coloured solid. The ${ }^{1} \mathrm{H}-\mathrm{NMR}$ spectrum (Figure A1.14) 
showed a singlet at $\delta=1.42 \mathrm{pm}$ integrating for nine protons. This was assigned to the methyl of the Boc group. Overlapping signals at $\delta=1.62 \mathrm{ppm}$ was assigned to two of the $-\mathrm{CH}_{2}$ of the compound, because the broad signal integrates for four protons. The multiplet at $\delta=3.15-3.18$ ppm and the doublet of doublets at $\delta=3.47 \mathrm{ppm}$ was assigned to the remaining $-\mathrm{CH}_{2}$ units, each integrating for two protons each. The singlet at $\delta=3.89 \mathrm{ppm}$ integrated for six protons corresponding to the protons of the methoxy group. The peak at $\delta=4.61 \mathrm{ppm}$ corresponded to the amine proton which integrated for one. The signal at $\delta=7.03,7.14$, and 7.67 ppm were doublet of doublets. These signals corresponded to the aromatic protons and each integrating for one proton. The broad signal at $\delta=7.99 \mathrm{ppm}$ was assigned to the other amine proton, integrating for one. The ${ }^{13} \mathrm{C}-\mathrm{NMR}$ (Figure A1.15) showed signal at $\delta_{C}=27.00,27.62,33.71$, and $39.27 \mathrm{ppm}$ which were assigned to the carbon atoms of the four methylene units in the chain. Signal at $\delta=$ 29.68 ppm corresponded to the methyl carbons of the Boc group. The methoxy carbons were observed at $\delta=56.19 \mathrm{ppm}$ and $61.28 \mathrm{ppm}$. The signals at $\delta=115.26,122.79$, and $124.44 \mathrm{ppm}$ were assigned to the unsubstituted aromatic carbons. The signal at $\delta=126.84$ ppm corresponded to the ipso carbon of the aromatic ring bound to the carbonyl group. The aromatic carbons (ipso carbons) that were bound to the methoxy group were seen at $\delta=147.39$ and $152.55 \mathrm{ppm}$. Last but not least, the two carbonyl carbons were both shown at $\delta=162.55$ and 165.21 ppm.

Elemental analysis is in agreement with the expected structure, where the "found" values were analogous within experimental error to the "calculated" values (see Experimental Section)

\subsubsection{N-Boc(1,4-aminobutyl)-[2,3-bis(benzyloxy)phenyl]benzamide (10)}

$N$-Boc(1,4-aminobutyl)-[2,3-bis (benzyloxy)phenyl]benzamide (10) was synthesized following the procedure shown in Scheme 17. The urea byproduct that is formed during the reaction is soluble in water and can be removed by extraction. The product was purified by flash chromatography which gave the title material as a yellow coloured solid with a $40 \%$ yield. 
The ${ }^{1} \mathrm{H}-\mathrm{NMR}$ (Figure A1.16) was analogues to the product $\mathrm{N}$-Boc(1,4-aminobutyl)-2,3(dimethoxyphenyl)benzamide except that there were no methoxy groups. The signals at $\delta=5.09$ and 5.16 ppm integrated for two protons each, were assigned to the protons of $-\mathrm{CH}_{2}$ of the two benzyl groups. The signals at $\delta=7.15 \mathrm{ppm}$ to $7.75 \mathrm{ppm}$ were the aromatic protons from the benzyl groups and the benzamide. This region integrated for a total of 13 protons. The last signal at $\delta=7.95 \mathrm{ppm}$ was assigned to the amine proton that integrated for one proton.

Elemental analysis is in agreement with the expected structure (see Experimental Section).

\subsection{Deprotection of Boc Protecting Group}

Boc protecting groups are generally removed by using mild acidic conditions such as TFA, either neat or in $\mathrm{DCM}$, and $\mathrm{HCl}$ in either $\mathrm{MeOH}$ or EtOAc. From different scientific journals and organic chemistry textbooks, ${ }^{26,27,28}$ many different attempts have been made to cleave Boc protecting group from compound 10.

Table 4: Different methods used to cleave Boc

\begin{tabular}{|c|c|c|c|c|}
\hline $\begin{array}{c}\text { Deprotecting } \\
\text { Agent }\end{array}$ & Solvent & Time & Condition & Product \\
\hline \multirow{2}{*}{ Water ${ }^{26}$} & DCM & $8 \mathrm{hrs}$ & Air, Reflux & $\mathrm{NO}$ \\
\hline & 1,4-dioxane & $\mathrm{O} / \mathrm{N}$ & $\mathrm{N}_{2}$, Reflux & NO \\
\hline $\mathrm{Bu}_{4} \mathrm{NF}^{27}$ & Dry THF & $8 \mathrm{hrs}$ & Air, Reflux & NO \\
\hline $\mathrm{HCl}$ (conc.) & $\mathrm{MeOH}$ & $1-3 \min$ & Air, RT & $\mathrm{NO}$ \\
\hline \multirow{2}{*}{ TFA (1 eq) } & DCM & $10,30 \mathrm{~min}$ & Air, RT & NO \\
\hline & $\begin{array}{l}\text { DCM } \\
\text { (1eq) }\end{array}$ & $1-3 \mathrm{~min}$ & Air, $0^{\circ} \mathrm{C}$ & $\begin{array}{l}\text { YES } \\
60 \%\end{array}$ \\
\hline
\end{tabular}

Table 4 displays the different methods used to remove the Boc group. Boc removal was conveniently carried out by the dissolution in TFA. ${ }^{28}$ Therefore, the only method that was successful was using one equivalent of TFA in one equivalent of DCM. ${ }^{28}$ The mechanism of the deprotection of Boc using TFA is shown in Scheme 18, where the by-products were carbon 
dioxide and isobutene. ${ }^{1} \mathrm{H}-\mathrm{NMR}$ displayed that the t-butyl from Boc was not there at $\delta=1.44 \mathrm{ppm}$ (Figure 2.6.1). This concluded that the Boc protecting group was cleaved from the benzamide compound. Initial attempts at dilute TFA concentration were unsuccessful as having an excess of DCM prevented Boc cleavage.

When $\mathrm{HCl}$ and $\mathrm{Bu}_{4} \mathrm{NF}$ (i.e., tetrabutylammonium fluoride) were used, starting material was retrieved and the Boc group was still present. As the "green method" alternative water was used as a deprotecting agent. At elevated temperatures of $150-275^{\circ} \mathrm{C}$, water can be used as a catalyst and reaction solvent in the removal of Boc protecting group. ${ }^{26}$ However, the method was unsuccessful after several of attempts and ${ }^{1} \mathrm{H}-\mathrm{NMR}$ analysis did not support the formation of the target compound. The chemical shifts and the integrals did not match with the proposed compound. 


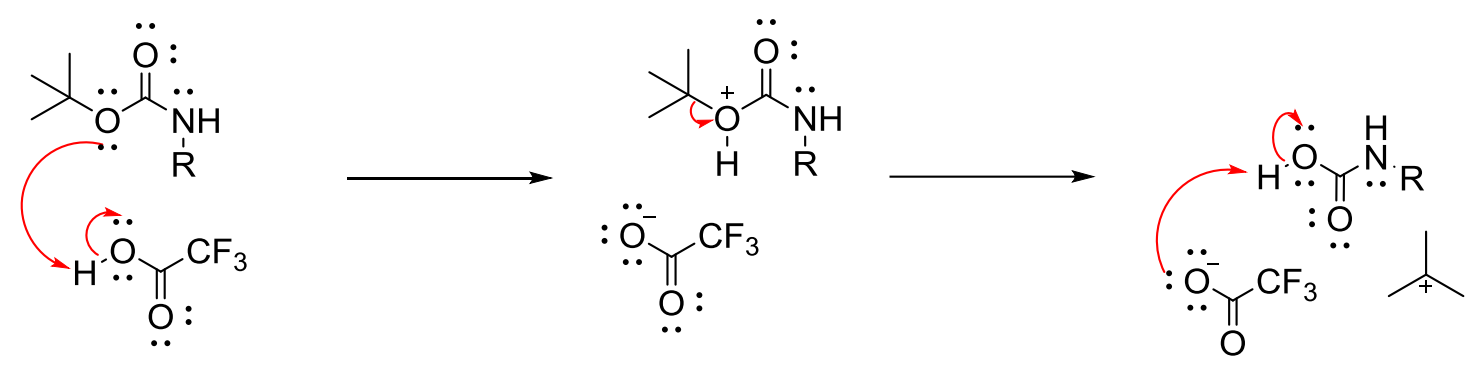

$\mathrm{TFA}=\mathrm{Excess}$

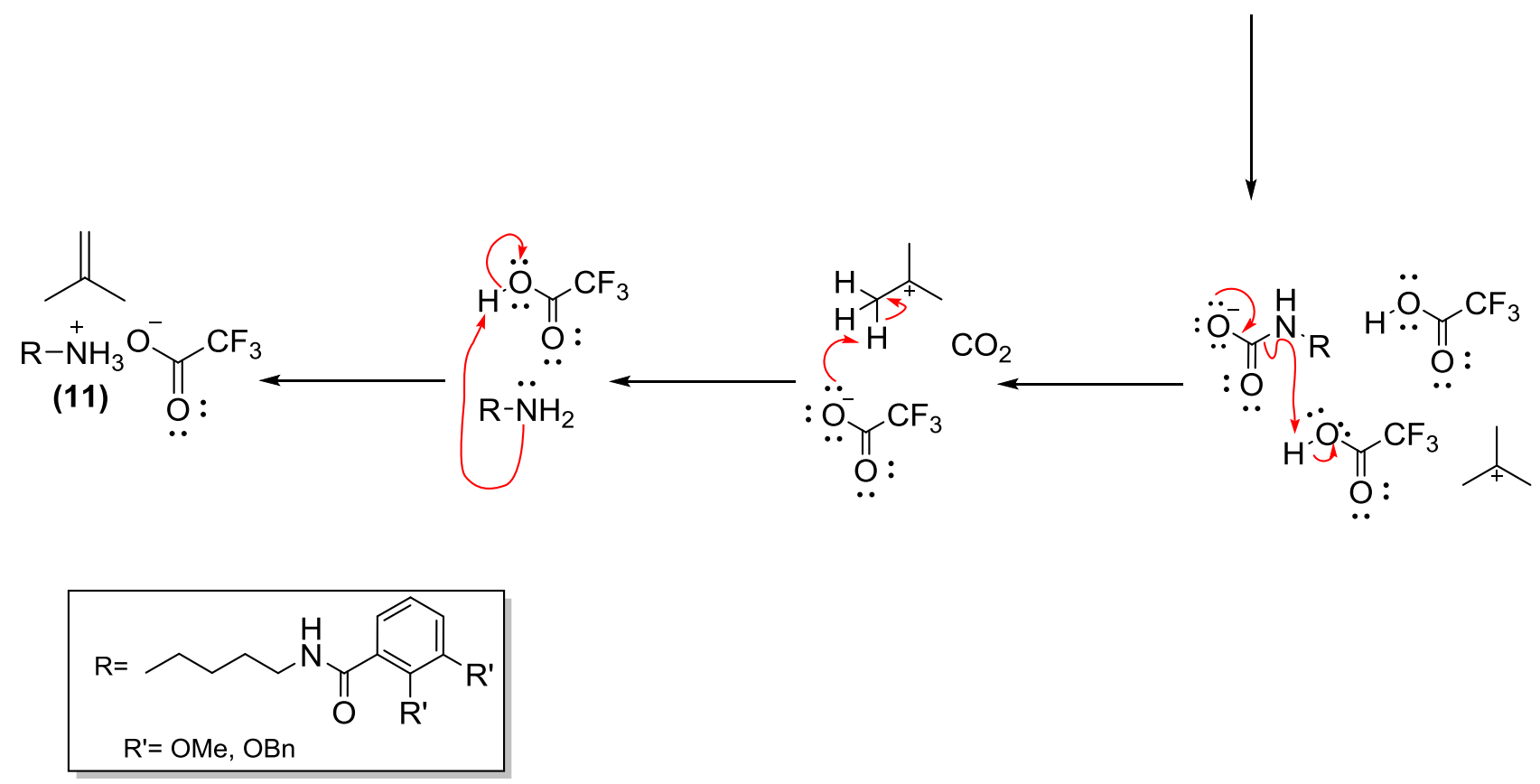

Scheme 18: General mechanism of deprotection of Boc

\subsubsection{1,4-aminobutyl)-[2,3-bis (benzyloxy)phenyl]benzamide (11)}

One equivalent of TFA with one equivalent of DCM was used to successfully deprotect the Boc group. This gave a white solid with a $60 \%$ yield. ${ }^{1} \mathrm{H}-\mathrm{NMR}$ analysis of the product indicated the presences of impurities, as one can see in Figure 2.6.1. Comparing the two ${ }^{1} \mathrm{H}-\mathrm{NMR}$ spectra (Figure 2.6.1), the peak at $\delta=1.45 \mathrm{ppm}$ integrated for nine protons was assigned to the $-\mathrm{CH}_{3}$ of the $t$-butyl group was not present in Figure 2.6.1 (top), that indicated the Boc group was removed from the compound. The slight shifts in ${ }^{1} \mathrm{H}-\mathrm{NMR}$ also shows that it was not identical to the starting 
material (10). The reactive nature of TFA made it hard for purification to be successful. Hence, the spectrum (Figure 2.6.1: top) was quite chaotic. This made it extremely complicated to assign peaks and integrate due to the fact that very little product was obtained to run ${ }^{1} \mathrm{H}-\mathrm{NMR}$, and product may have been lost during extraction.

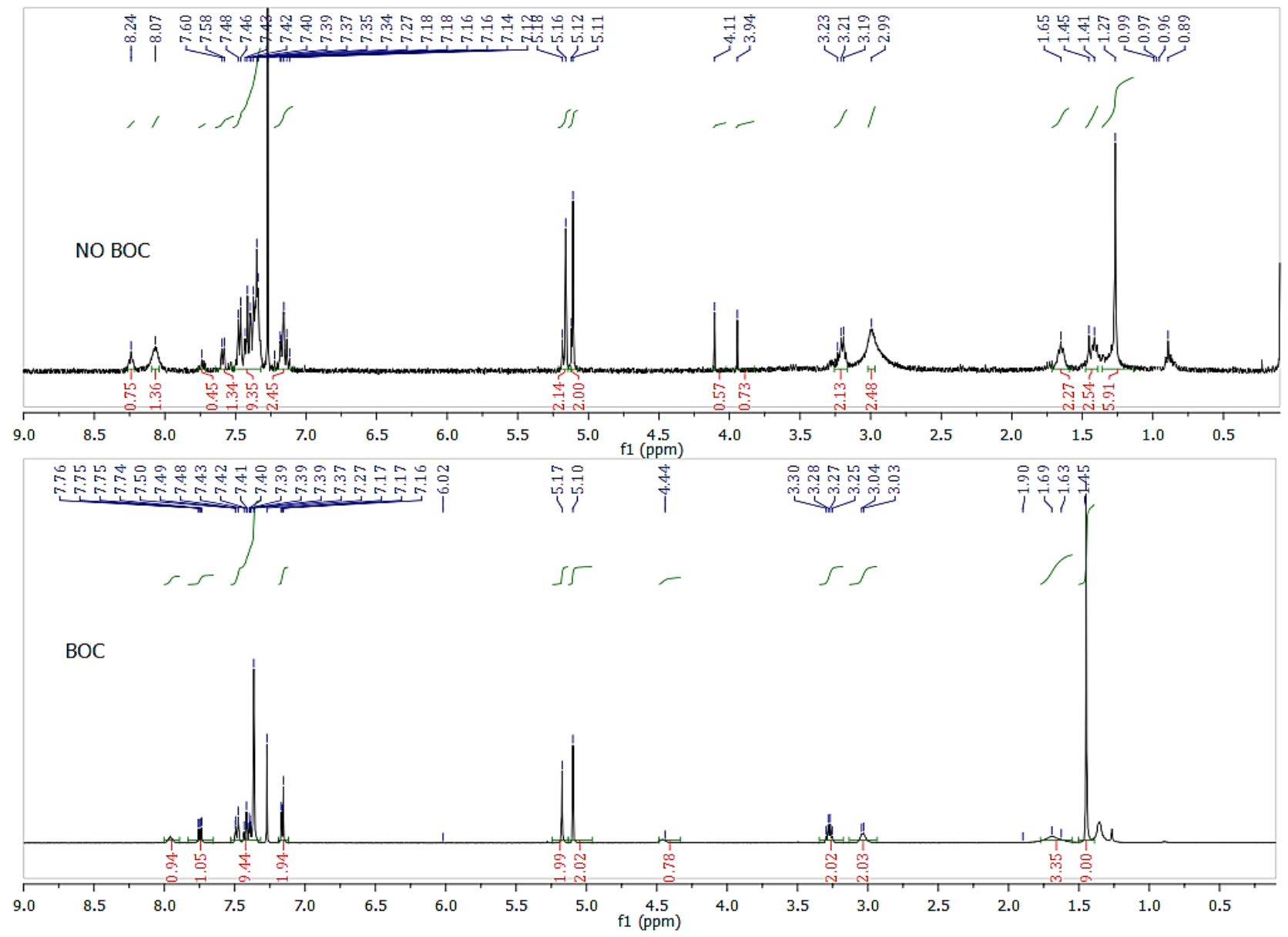

Figure 2.6.1: Comparing ${ }^{1} \mathrm{H}-\mathrm{NMR}$ of Boc (10) and No Boc (11)

2.7 Synthesis of the Benzamide: Part II

The starting material Boc-1,4-diaminobutane (8) was expensive to purchase, synthesizing was time consuming, and having to deprotect it was problematic. It was decided to synthesize the second building block without needing to protect the $\mathrm{NH}_{2}$<smiles>O=C(n1ccnc1)n1ccnc1</smiles>
CDI<smiles>CN(C)C(On1nnc2ccccc21)=[N+](C)C</smiles>

HBTU

Figure 2.7.1: Structure of CDI and HBTU group with Boc. Since it is an amide synthesis, amide bond formation was prepared in several 
ways using coupling reagent or acid chloride (using $\mathrm{SOCl}_{2}$ ). Different types of coupling reagents were used such as CDI, EDC.HCl, HBTU, and DMTMM (Scheme 19 and Table 5).
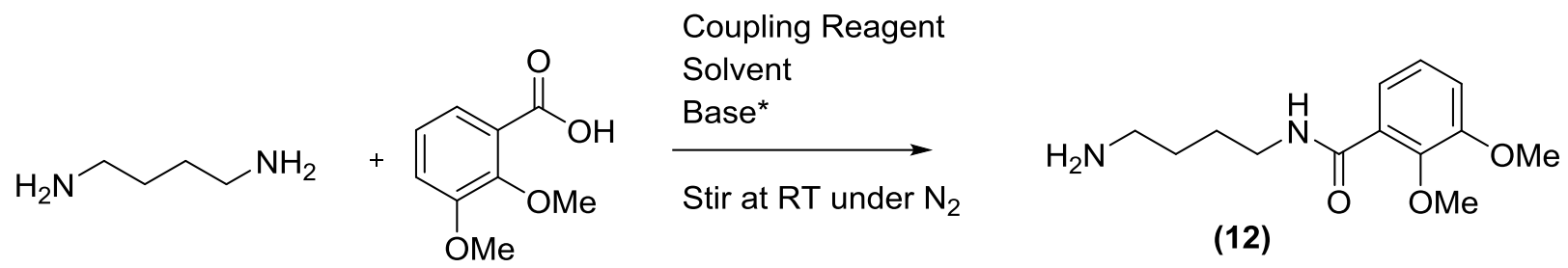

*not always added

Scheme 19: Synthesis of $N$-(2,3-dimethoxybenzoyl)diaminobutane (12) using a coupling reagent

CDI (i.e. N,N'-carbonyldiimidazole) (Figure 2.7.1) and DMTMM (i.e., 4-(4,6-Dimethoxy-1,3,5triazin-2-yl)-4-methylmorpholinium chloride) (14) is a one pot coupling procedure. These two coupling agents do not require additional base. ${ }^{19} \mathrm{CDI}$ reagent is usually used on a large scale and DMTMM is effective coupling agent for ester, amide, and peptide synthesis. HBTU $\left(N, N, N^{\prime}, N^{\prime}-\right.$ Tetramethyl-O-(1H-benzotriazol-1-yl)uronium hexafluorophosphate) (Figure 2.7.1) and $\mathrm{EDC} \cdot \mathrm{HCl}$ ( $N$-(3-dimethylaminopropyl)- $N$ '-ethylcarbodiimide hydrochloride) are also a one-pot synthesis but require base (triethylamine: $\mathrm{Et}_{3} \mathrm{~N}$ ). The driving force is the making of the by-product - urea derivative. ${ }^{19}$

Table 5: Reaction conditions for $N$-(2,3-dimethoxybenzoyl)-1,4-diaminobutane synthesis

\begin{tabular}{|c|c|c|c|c|c|}
\hline $\begin{array}{l}\text { Coupling } \\
\text { Reagent }\end{array}$ & Base & Solvent & Mole ratio & Condition & Product \\
\hline CDI & - & $\begin{array}{l}\text { DCM,THF, } \\
\mathrm{MeOH}\end{array}$ & $1: 1,2: 1$ & $\begin{array}{l}\text { Stirred O/N at RT under } \\
\qquad \mathrm{N}_{2}\end{array}$ & $\mathrm{NO}$ \\
\hline $\mathrm{EDC} \cdot \mathrm{HCl}$ & $\mathrm{Et}_{3} \mathrm{~N}$ & DCM & $1: 1$ & $\begin{array}{l}\text { Stirred OWN at RT under } \\
\qquad \mathrm{N}_{2}\end{array}$ & NO \\
\hline HBTU & $\mathrm{Et}_{3} \mathrm{~N}$ & DCM & $\begin{array}{c}1: 1.1,2.5: 1 \\
5: 1\end{array}$ & $\begin{array}{c}\text { Stirred } 19 \text { hrs at RT } \\
\text { under } \mathrm{N}_{2}\end{array}$ & NO \\
\hline DMTMM & - & $\begin{array}{c}\mathrm{MeOH}, \mathrm{THF}, \\
\mathrm{DCM}\end{array}$ & $1.1: 1,2.5: 1$ & $\begin{array}{c}\text { Stirred } 19 \text { hrs at RT } \\
\text { under } \mathrm{N}_{2}\end{array}$ & $\begin{array}{l}\text { YES } \\
(9 \%)\end{array}$ \\
\hline
\end{tabular}

${ }^{*} 1,4-$ diaminobutane usually in excess 
CDI did not work as a good coupling reagent to synthesize the second building block. The solvent $\mathrm{MeOH}$ and THF did not dissolve the starting materials fully. DCM was a good solvent since both starting materials (1,4-diaminobutane and 2,3-dimethoxy benzoic acid) dissolved. However, after the liquid-liquid extraction, the organic layer did not have the product. There was nothing shown in the aromatic region in ${ }^{1} \mathrm{H}$-NMR spectrum. There was also a lot of by-product (imidazole) in the organic layer which was difficult to remove.

EDC. $\mathrm{HCl}$ worked well to synthesize the amide for the first building block but did not succeed in synthesizing the second building block. ${ }^{1} \mathrm{H}-\mathrm{NMR}$ spectrum was very messy, and came to a conclusion that the two starting materials never coupled together. Carbodiimides are mild amide coupling reagents, which is the reason why EDC. $\mathrm{HCl}$ did not work this time. An even more efficient, expensive, and exotic coupling reagent is HBTU.

HBTU coupling reagent gave a clean ${ }^{1} \mathrm{H}-\mathrm{NMR}$ spectrum, however the product formed $N, N^{\prime}$-Bis $(2,3$ -bis(methoxy)benzoyl)-1,4-diaminobutane (13, Figure 2.7.2) and not the title compound. Similar result happened when the acid chloride reaction took place following the same reaction as Scheme 19 with the same conditions from Scheme 10 (a).<smiles>COc1cccc(C(=O)NCCCCNC(=O)c2cccc(OC)c2OC)c1OC</smiles>

Figure 2.7.2: Compound 13 is formed when using $\mathrm{HBTU}$ or $\mathrm{SOCl}_{2}$

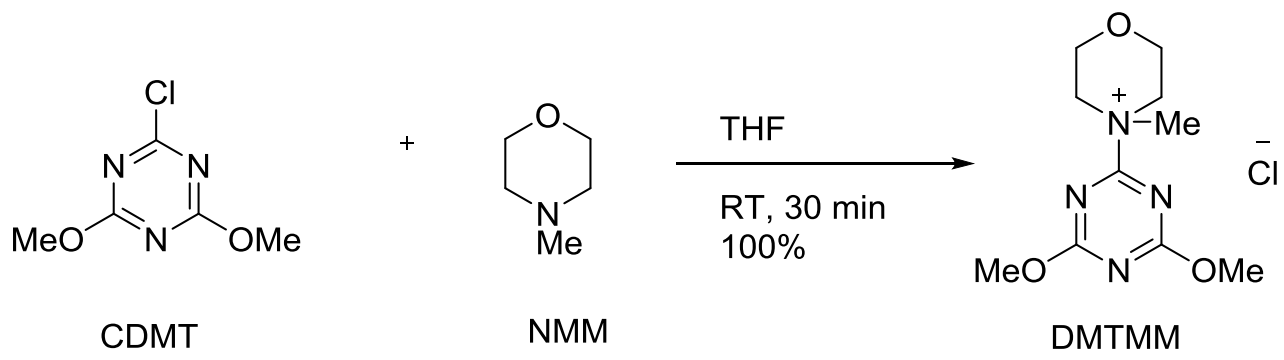

(14)

Scheme 20: Synthesis of DMTMM (14) 
DMTMM (14) (Figure A1.22) was first synthesized (Scheme 20) and then used as a coupling reagent. Compound 14 is stable in $\mathrm{MeOH}$ and THF, and that is why those were the solvents used first in the reaction (Scheme 19). DMTMM has been reported to decompose in DCM after three hours. $^{29}$

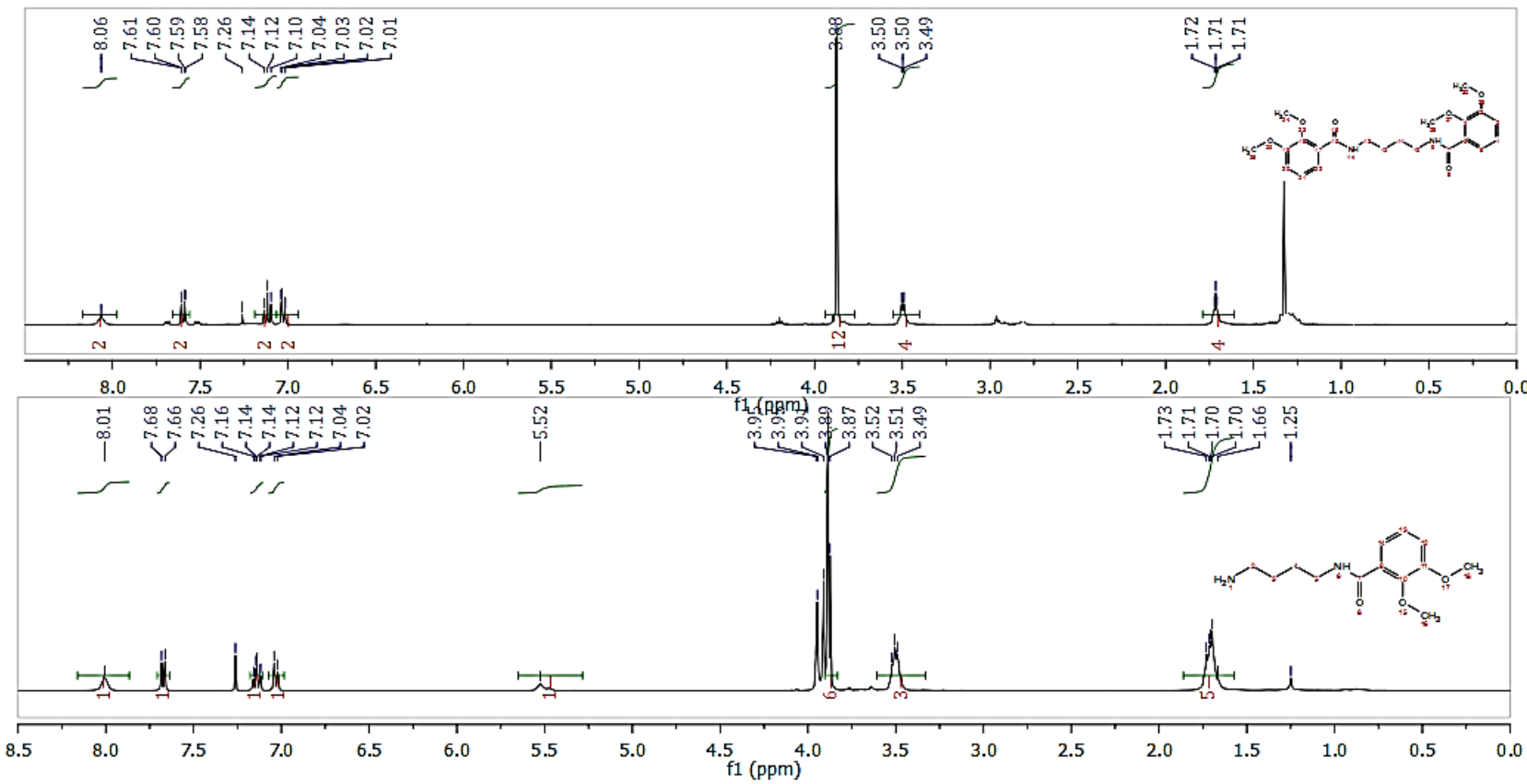

Figure 2.7.3: Compound 13 (top spectrum - using HBTU) Vs Compound 12 (bottom spectrum-using $D M T M M$ ) in $\mathrm{CDCl}_{3}$

However, the synthesis failed when the solvent THF or MeOH were used, due to the poor solubility of the starting materials. DCM was then used and the product was successfully synthesized with only few impurities (Figure A1.17). The comparison between the actual compound 12 and compound 13 is shown in Figure 2.7.3.

\subsubsection{N-(2,3-dimethoxybenzoyl)-1,4-diaminobutane) (12)}

The triazinone (4,6-dimethoxy-1,3,5-triazin-2(1H)-one) by-product was separated from the product by flash chromatography (eluting with only ethyl acetate) and preparative TLC. This gave a white solid with a 9\% yield as the title product using DMTMM. ${ }^{1} \mathrm{H}-\mathrm{NMR}$ (Figure A1.17) analysis of $\mathrm{N}$-(2,3-dimethoxybenzoyl)-1,4-diaminobutane) in $\mathrm{CDCl}_{3}$ showed a signal at $\delta=1.73$ to 1.66 ppm which integrated for five protons. The multiplet at $\delta=3.52-3.49 \mathrm{ppm}$ integrated for three 
protons. Both peaks were assigned to the $-\mathrm{CH}_{2}$ of the 1,4-diaminobutane moiety. The broad peak at $\delta=5.52 \mathrm{ppm}$ was assigned to the amine proton. The doublet at $\delta=7.03 \mathrm{ppm}$ and $7.67 \mathrm{ppm}$ integrated for one proton each. The doublet of doublets at $\delta=7.14 \mathrm{ppm}$ integrated for one proton. These were assigned to the aromatic protons of the product. The broad peak at $\delta=8.01 \mathrm{ppm}$ was assigned to the amine proton integrating for one proton. 2D-NMR was performed (COSY, HSQC, HMBC) and this confirmed the title product was synthesized successfully (Figure A1.18, A1.19, A1.20). However, ${ }^{1} \mathrm{H}-\mathrm{NMR}$ indicated there was still some triazinone even after the purification step. The peak at $\delta=3.95$ ppm was assigned to the protons of the methoxy groups in the by-product. The percent yield was very low because the product may be lost during the purification step (flash chromatography and prep TLC). Also, two compounds were produced in this reaction using DMTMM, which were compounds 12 and 13 that was why the desired product obtained was very small.

\subsubsection{N,N'-Bis(2,3-bis(methoxy)benzoyl)-1,4-diaminobutane (13)}

Unfortunately, (12) was unable to be synthesized using thionyl chloride and/or HBTU. However, the reaction produced a byproduct instead (Figure 2.7.1). Compound 13 was isolated in poor yields but was useful for further study. The two studies that were completed with compound 13 were: (i) the demethylation of the methyl aryl ether and (ii) its binding properties with Fe (III). The binding studies were performed using UV-Vis, and computational calculations (e.g. DFT) were performed using Spartan 10' (Shown in Section 2.11). The reason these studies were conducted is because the compound $\mathbf{1 3}$ is a catechol compound and catechol derivatives have been a great interest to many scientists, since they act as a chelating ligand in siderophores (e.g. Photobactin, Enterbactin, etc).

$N, N$ '-Bis(2,3-bis(methoxy)benzoyl)-1,4-diaminobutane (13) is a white crystal line compound with a 27\% yield. ${ }^{1} \mathrm{H}$-NMR (Figure A1.21) chemical shift values were identical to the reported values stated by K. Winstanely and D. Smith. ${ }^{30}$ 


\subsection{Demethylation Using $\mathrm{BBr}_{3}$}

Demethylation is the removal of a methyl group from a molecule. Boron tribromide $\left(\mathrm{BBr}_{3}\right)$ is the most effective reagent used for cleaving methyl aryl ethers. This reagent was used to demethylate the methoxy groups on compound 13 shown in Scheme 22 as a test trial. The mechanism of methyl aryl ether demethylation (Scheme 21) continues through the formation of a complex between the boron and the ether oxygen followed by the removal of bromomethane to yield dibromophenoxyborane. The dibromophenoxyborane undergoes hydrolysis to produce phenol, boric acid, and hydrogen bromide as the products. ${ }^{31}$

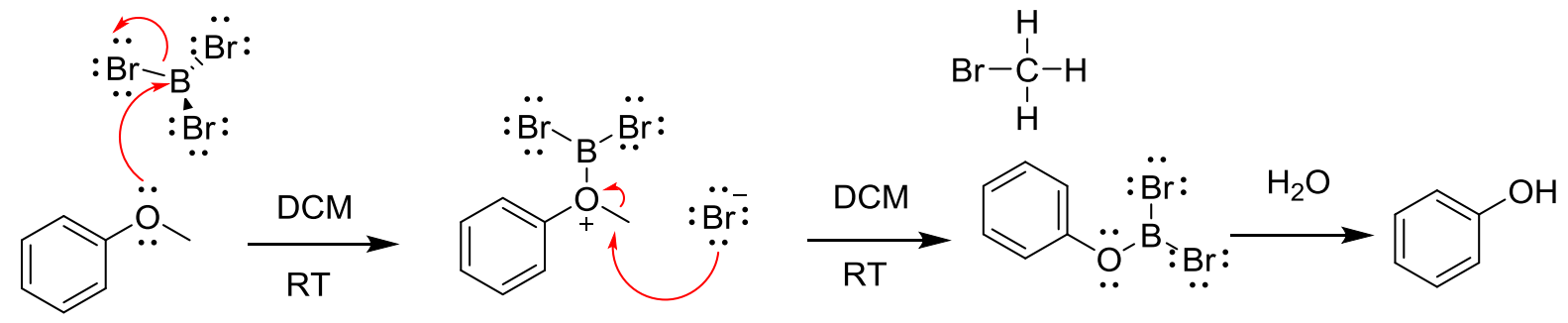

Byproducts : bromomethane, boric acid, and hydrogen bromide

Scheme 21: Mechansim of demethylation using $\mathrm{BBr}_{3}$<smiles>COc1cccc(C(=O)NCCCCNC(=O)c2cccc(OC)c2OC)c1OC</smiles>

${ }^{*} \mathrm{BBr}_{3}$ is added at $-84{ }^{\circ} \mathrm{C}$

(13)

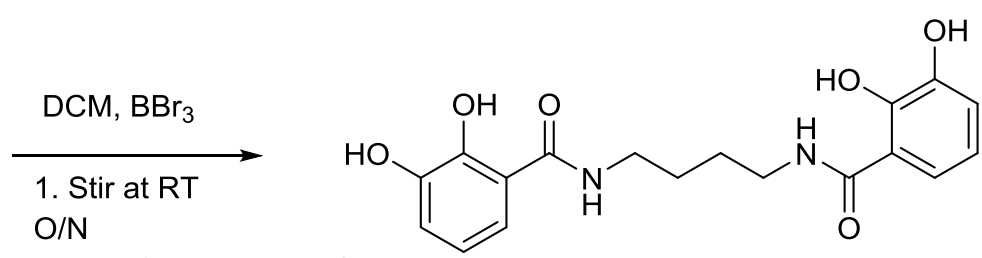

2. $-84{ }^{\circ} \mathrm{C}$ add Anh.MeOH

Sat. $\mathrm{NaHCO}_{3}, \mathrm{H}_{2} \mathrm{O}$.

3. Extract with EtOAc

(15)

Scheme 22: Demethylation of compound 13

\subsubsection{N,N'-Bis(2,3-dihydroxybenzoyl)-1,4-diaminobutane (15)}

$N, N$ '-Bis(2,3-dihydroxybenzoyl)-1,4-diaminobutane was synthesized by deprotecting the methoxy groups using boron tribromide shown in Scheme 22. Water was added to the reaction flask after the reaction was complete at $-84^{\circ} \mathrm{C}$ until addition no longer caused the evolution of $\mathrm{HBr}$. Methanol 
was then added to remove boron impurities such as boric acid and bromomethane. No purification was needed and gave a whitish-grey solid with a $77 \%$ yield.

${ }^{1} \mathrm{H}-\mathrm{NMR}$ (Figure A1.23) is consistent with data previously reported by K. Winstanley and D. Smith. ${ }^{30}$ The NMR chemical shift are shifted slightly (downfield) because $\mathrm{CD}_{3} \mathrm{OD}$ was used while the reported ${ }^{1} \mathrm{H}-\mathrm{NMR}$ was in DMSO- $d_{6}$. Since $\mathrm{CD}_{3} \mathrm{OD}$ was used, the hydroxyl $(-\mathrm{OH})$ and amine protons $(-\mathrm{NH})$ were not observed on the spectrum. $\mathrm{MeOH}-d_{4}$ exchanges out the exchangeable protons from hydroxyl, amine, or amide protons with deuterium. This compound was only soluble in $\mathrm{CD}_{3} \mathrm{OD}$ and insoluble in $\mathrm{CDCl}_{3}$ and acetone- $d_{6}$.

$N, N$ '-Bis(2,3-dihydroxybenzoyl)-1,4-diaminobutane (15) displayed a UV-Vis spectrum typical for catechol ligands with an absorbance peak $\left(\lambda_{\max }\right)$ at $318 \mathrm{~nm}$ resulting from the $\pi-\pi^{\star}$ transition (Figure A2.1). The catechol ligand absorb near Ultraviolet light $(\lambda=300-400 \mathrm{~nm})^{17}$ and the molar absorptivity at $318 \mathrm{~nm}$ was calculated to be $677 \mathrm{M}^{-1} \mathrm{~cm}^{-1}$.

\subsection{Alternative Route}

The main method taken to attempt to synthesize Photobactin is presented in Scheme 7, while this was being done, an alternative approach was also taken. This required synthesizing the oxazoline in the final step rather than in the beginning steps. The alternative procedure is shown in Scheme 23, and was inspired by the work of R. Bergeron, J. Garlich, and J. McManis. ${ }^{32}$ 


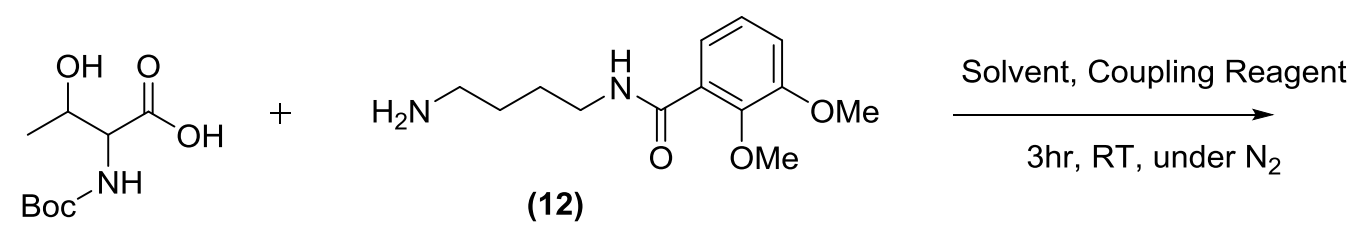<smiles>COc1cccc(C(=O)NCCCCNC(=O)C(N)C(C)O)c1OC</smiles><smiles>CCOC(=N)c1cccc(O)c1O</smiles><smiles>[R10]C#N</smiles>

Scheme 23: An alternative approach to synthesize Photobactin

Boc-L-Threonine couples to compound $\mathbf{1 2}$ using a coupling reagent such as DMTMM, HBTU, or EDC. HCl. The Boc is then cleaved using TFA and the methyl aryl ethers are deprotected using $\mathrm{BBr}_{3}$. The final step is the cyclization to produce the oxazoline, which occurs by adding ethyl 2, 3dihydroxybenzimidate in the reaction flask with methanol and refluxing under nitrogen for approximately 24 hours, is intended to afford Photobactin (Scheme 23). 
<smiles>CCOC(=O)COC(=O)c1cccc(O)c1O</smiles><smiles>O=Cc1cccc(OCc2ccccc2)c1OCc1ccccc1</smiles>

(16)<smiles>O=C(O)c1cccc(OCc2ccccc2)c1OCc1ccccc1</smiles>

(17)

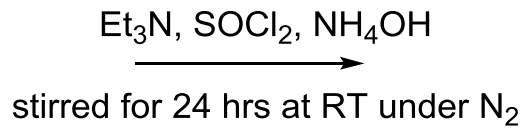<smiles>NC(=O)c1cccc(OCc2ccccc2)c1OCc1ccccc1</smiles>

(18)

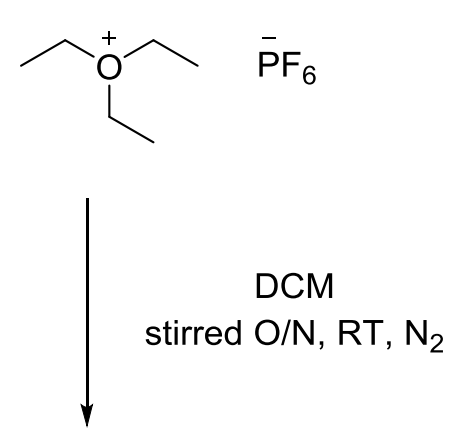<smiles>CCOC(=N)c1cccc(OCc2ccccc2)c1OCc1ccccc1</smiles>

(19)

Scheme 24: The synthesis of ethyl 2,3-dihydroxybenzimidate (19)

The ethyl-2,3-bis(benzyloxy) benzimidate (19) was synthesized followed by a literature procedure, which is shown in Scheme $24 .^{33}$ In the last step of Scheme 24, compound 18 with triethyloxonium hexafluorophosphate which acts as a catalyst activating agent afforded an imine compound (19). ${ }^{1} \mathrm{H}-\mathrm{NMR}$ chemical shifts for compounds 16 to 19 were consistent with data reported (Figure A1.24-A1.27). ${ }^{33,34}$ The final step is then removing the benzyl group by catalytic 
hydrogenation using activated Palladium on carbon with $\mathrm{H}_{2}$ to afford ethyl-2,3dihydroxybenzimidate, which would be used in Scheme $\mathbf{2 3}$ for the cyclization step.

The attempt to couple the Boc-L-Threonine with compound 12 was not successful. The coupling reagent used was DMTMM. However, ${ }^{1} \mathrm{H}-\mathrm{NMR}$ spectrum showed only starting materials. This could be due to the fact that DMTMM is not a good coupling reagent for this type of reaction or the by-product of the compound 12, triazinone, could have interfered with the reaction. Either way, another coupling reagent can be used such as $\mathrm{HBTU}$ or EDC.HCl, since they are both one pot synthesis, and may work more effectively than DMTMM.

\subsection{Analogue of Photobactin}

The analogue of Photobactin is mainly different from the first building block (oxazoline acid). Compound $\mathbf{2 1}$ was prepared using strategy equivalent to that employed for the total synthesis of Mycobactin S (Scheme 25). ${ }^{15}$ Compound 21 is incorporated in Mycobactin S, Transvalencin Z, and Parabactin. Figure 2.10.1 displays the difference between the two Photobactin structures. The oxazoline fragment cyclized easier with the L-Serine methyl ester than with L-Threonine

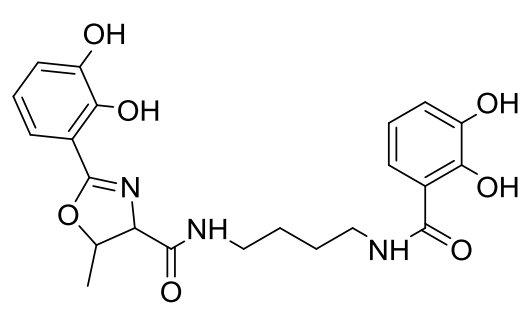

Photobactin

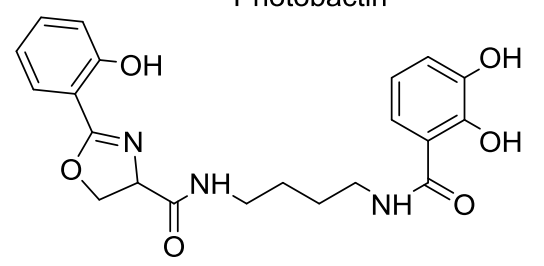

Analogue of Photobactin methyl ester. The Burgess reagent was used to synthesize compound 21, which is a milder dehydrative reagent than Methyl DAST. Compounds 5 and 6 were not able to synthesize when using the Burgess reagent, this can be due to the extra $-\mathrm{OH} /$-OMe on the phenyl moiety and

Figure 2.10.1: Structure of Photobactin and the analogue of Photobactin the $-\mathrm{CH}_{3}$ group on the $L$-Threonine. The $-\mathrm{CH}_{3}$ group on the $L$-Threonine residue can affect cyclization when using the Burgess reagent because invertive cyclization arises at the $\beta$-position (Scheme 26 ), which may require a 
longer reaction time (> $24 \mathrm{hrs})$. Also, having two $-\mathrm{OMe} /-\mathrm{OH}$ on the phenyl makes it much more challenging for cyclization to occur, than having simply one of such groups.

On the other hand, several dehydrating reagents promote the dehydrative cyclization of the amide ( $L$-Threonine residue) as mentioned in Section 2.3. It is debatable, which dehydrative reagent (e.g. Burgess reagent, Methyl DAST, thionyl chloride) proceeds with an inversion of configuration (stereochemistry) at the $\beta$-position of the $L$-Threonine residue. Methyl DAST can proceed in an inversion configuration, but it is not definite. If that is the case, $L$-allo-Threonine is required to be used as a substitute in order to prevent inversion.<smiles>O=C(O)c1ccccc1OCc1ccccc1</smiles><smiles>COC(=O)[C@H](N)CO</smiles>

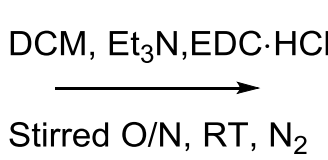<smiles>CC(=O)[C@H](CO)NC(=O)c1ccccc1OCc1ccccc1</smiles>

(20)<smiles>CC(=O)C(CO)NC(=O)c1ccccc1OCc1ccccc1</smiles>

(20)
Burgess Reagent, THF

Reflux for 30 min<smiles>COC(=O)C1COC(c2ccccc2OCc2ccccc2)=N1</smiles>

(21)

Scheme 25: Synthesis of compound 21 via Burgess reagent 


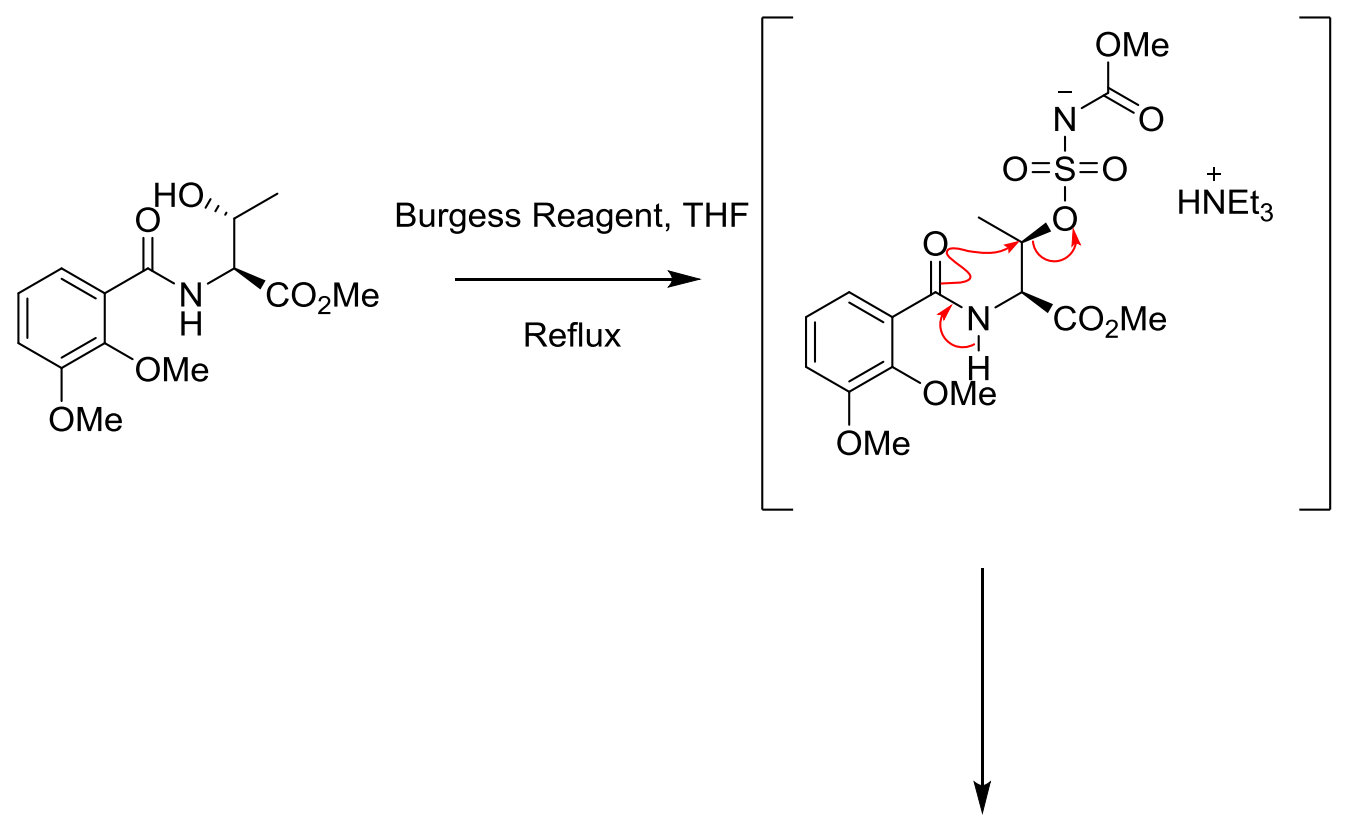

Inversion of configuration<smiles>COC(=O)C1N=C(c2cccc(OC)c2OC)O[C@@H]1C</smiles><smiles>CCN(CC)C(=O)NS(=O)(=O)O</smiles>

By-products

Scheme 26: Using Burgess reagent to yield an oxazoline

2.10.1 N-[2-(benzyloxy)benzoyl]-L-Serine methyl ester (20)

Compound 20 was isolated as yellowish-white coloured crystals with a $30 \%$ yield after recrystallization with toluene.

The ${ }^{1} \mathrm{H}-\mathrm{NMR}$ spectrum showed (Figure A1.29) a singlet with a chemical shift at $\delta=3.66 \mathrm{ppm}$ integrating for three protons. This signal was assigned to the methyl group. The multiplets at $\delta=$ 3.84-3.89 ppm and at $\delta=4.80-4.82 \mathrm{ppm}$ were assigned to the $-\mathrm{CH}_{2}$ and $-\mathrm{CH}$ of the amide moiety. The singlet at $\delta=5.21 \mathrm{ppm}$ which integrated for two protons was assigned to the $-\mathrm{CH}_{2}$ of the benzyl functional group. The signals at $\delta=7.07-7.47$, and $8.16 \mathrm{ppm}$ were assigned to the aromatic 
protons that integrated for nine protons. The doublet at $\delta=8.74 \mathrm{ppm}$ was assigned to the amide proton.

2.10.2 (S)-Methyl-2-[2-Benzyloxy)phenyl]-1,3-oxazoline-4-carboxylate (21)

(S)-Methyl-2-[2-Benzyloxy)phenyl]-1,3-oxazoline-4-carboxylate (21) was synthesized following Scheme 22. Compound 21 was a yellow coloured oil with a $60 \%$ yield. The ${ }^{1} \mathrm{H}-\mathrm{NMR}$ spectrum (Figure A1.30) showed a singlet with a chemical shift $(\delta)$ at 3.83 ppm integrating for three protons. The multiplet at $\delta=4.57-4.62 \mathrm{ppm}$ was assigned to the $-\mathrm{CH}_{2}$ on the oxazoline ring, integrating for two protons. The doublet of doublets at $\delta=4.99 \mathrm{ppm}$ was assigned to the $-\mathrm{CH}$ which integrated for one proton on the oxazoline ring. The singlet at $\delta=5.21 \mathrm{ppm}$ integrates for two protons and was assigned to the $-\mathrm{CH}_{2}$ of the benzyl functional group. The nine aromatic protons were shown at $\bar{\delta}_{\mathrm{H}}=7.01,7.31-7.53$, and $7.82 \mathrm{ppm}$.

\subsection{Binding Studies with $\mathrm{Fe}^{3+}$}

Binding studies were conducted through UV-Vis and computational chemistry using Spartan'10. The spectroscopic investigation of the binding between $\mathrm{Fe}^{3+}$ and the simple material (15) was undertaken as a guide, and for training purposes, with the later intention of using similar techniques with Photobactin. Compound 15 displayed a UV-Vis spectrum typical for catechol 7,13,14 seen in siderophores, with an absorption peak at $318 \mathrm{~nm}$ resulting from a $\pi-\pi^{*}$ transition of catechol siderophore (Figure A2.1). Upon the addition of $\mathrm{FeCl}_{3}$, two absorption peaks were observed, $319 \mathrm{~nm}$ and $572 \mathrm{~nm}$, and the solution turned from colourless to bluish-purple (Figure A2.1). An absorption peak at $319 \mathrm{~nm}$ was assigned to a ligand-to-metal charge transfer (LMCT) band characteristic for $\mathrm{Fe}^{3+}$ tetrahedrally coordinated complex. In addition, the broad absorption peak at $572 \mathrm{~nm}$ was assigned to the spin forbidden $\mathrm{d}-\mathrm{d}$ transition. ${ }^{6}$ This suggested that the siderophore was isolated mainly in the iron-free form and formed a complex with iron $\left(\mathrm{Fe}^{3+}\right)$ upon the addition of iron. Therefore, in LMCT for $\mathrm{d}^{5}$ complex, there are two absorptions bands one near $250 \mathrm{~nm}$ and the other near $600 \mathrm{~nm}$ which correlates to Figure A2.1. The binding constant was 
calculated from carrying out UV-Vis. The binding (formation) constant for compound 15 is $(\mathrm{K}) \mathbf{4 2 1}$, which is common. The higher the binding constant, the stronger the interaction between the ligands and the metal ion (e.g. $\mathrm{Fe}^{3+}$ ) which is mentioned in Section 1.3: Figure 1.3.1.
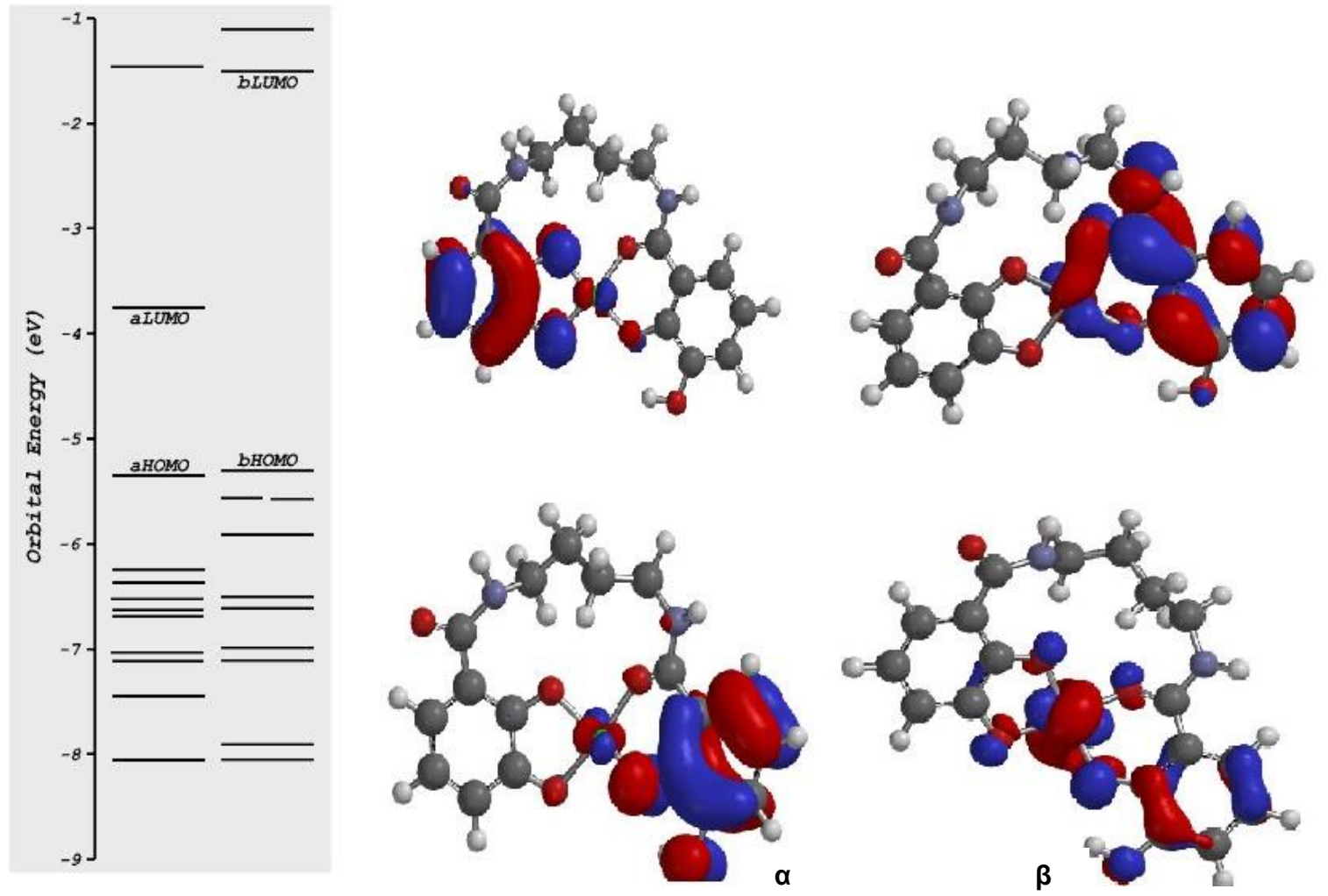

Figure 2.11.1: Orbital energy of compound 15 calculated using DFT (B3LYP/6-31G*)

Frontier orbitals are the most important orbitals in molecules for chemical reactivity. These are called HOMO (highest occupied molecular orbital) and LUMO (lowest unoccupied molecular orbital). ${ }^{17} \mathrm{HOMO}$ is the orbital of highest energy that is occupied, it is the easiest to remove electrons from this orbital (electron donor). LUMO is the lowest lying orbital that is empty, so it is easy to add more electrons into this orbital (electron acceptor). In Figure 2.11.1, the $\alpha$-spin HOMO and LUMO are ligand based orbitals and the $\beta$-spin HOMO and LUMO are mixed metal-ligand based orbitals. The aHOMO density is largely located on the dihydroxybenzoyl moiety and the 
aLUMO density is mainly located on the other dihydroxybenzoyl moiety. The $\beta \mathrm{HOMO}$ and $\beta$ LUMO densities are mainly located on the metal (Fe) and the dihydroxybenzoyl group (Figure 2.11.1).

Moreover, from the UV-Vis for compound 15, the $\varepsilon_{\max }$ is $1645.100 \mathrm{~L} \mathrm{~mol}^{-1} \mathrm{~cm}^{-1}\left(\varepsilon>10^{3}\right)$ which is indicative of the LMCT at $\lambda_{\max }$ is $319 \mathrm{~nm}$. This specifically means that the absorption band is very intense, ${ }^{35}$ as displayed in Figure A2.1. This LMCT can also be observed in Figure 2.11.1, as the electron transfer from aHOMO (ligand based) to $\beta$ LUMO (mixed metal-ligand based) in compound 15 with $\mathrm{Fe}^{3+}$.

Possible bonding modes have been investigated by molecular modeling where the suggested binding of Photobactin is the loss of the $\mathrm{H}^{+}$from the catechol or amide. The tertiary nitrogen on the oxazoline participates as coordinating ligand based on $\mathrm{p} K_{\mathrm{a}}$ and resonance mentioned in Section 1.3. If placed in an aqueous solution, the oxygen from the water can coordinate to $\mathrm{Fe}^{3+}$ as well (Figure 2.11.2). The DFT calculations were performed where the B3LYP/6-31G* method is used to predict vibrational frequencies of Fe-Photobactin complexes $\left(\mathrm{Fe}^{3+}\right)$.
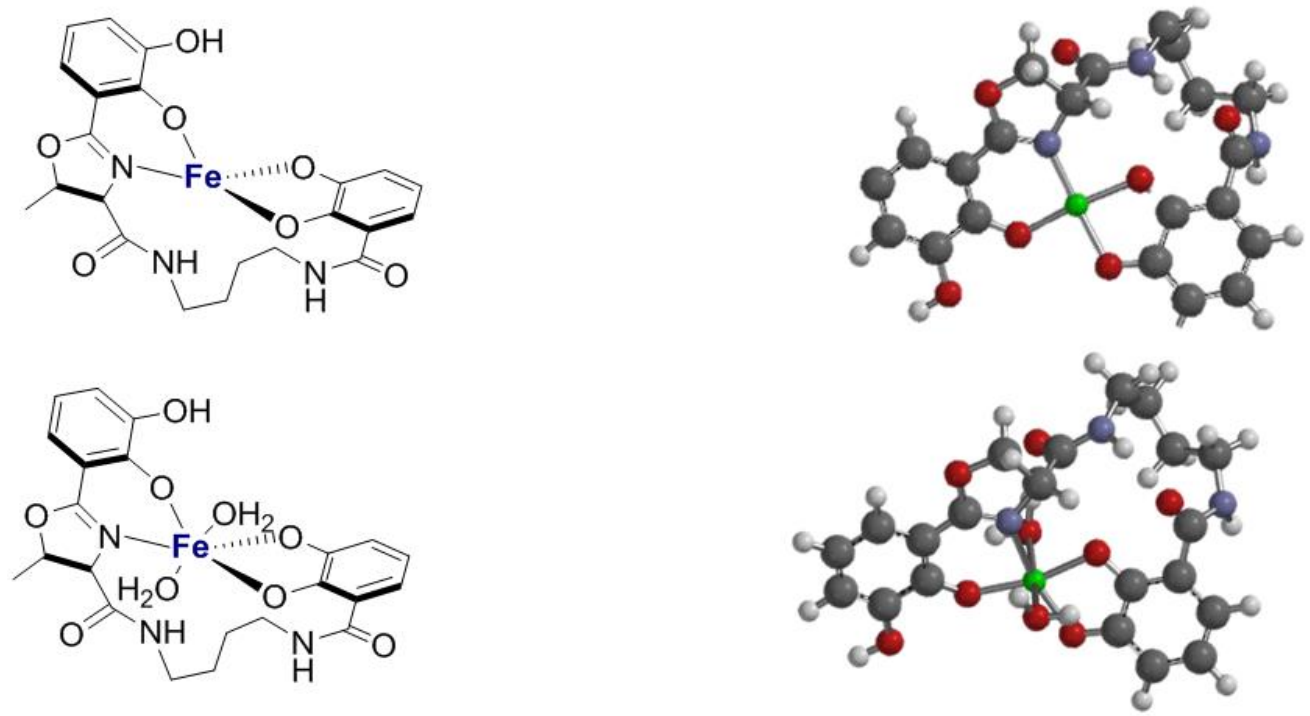

Figure 2.11.2: Possible Fe-Photobactin complexes calculated using DFT (B3LYP/6-31G*)

In Figure 2.11.2 two molecular models are shown. The top is a distorted square planar while the bottom is the octahedral. The bond lengths and bond angles are slightly distorted. The energies 
for the square planar and octahedral complexes are $-7367507.02 \mathrm{~kJ} / \mathrm{mol}$ and $-7566545.54 \mathrm{~kJ} / \mathrm{mol}$ respectively. Based on these calculations, it is hypothesized that Fe-Photobactin complex will be a hexadentate (6-coordinate ligand), because the Fe-Photobactin forms a soluble complex, and oxygen from the water will partake in the binding site. Also, the energy for the two molecular models are different, which means octahedral is preferred because it has a larger negative energy than the square planar, that indicates it is more stable. The large negative energy represents how much energy is released when the molecule is formed by bringing together all its nuclei and all its electrons. $^{35}$

The predicted UV-Vis was also calculated for Photobactin at the B3LYP level of theory (Figure A2.2). Fe-Photobactin complex was not calculated due to the maximum number of cycles reached. Comparing the literature to the predicted UV-Vis reveals that they are similar. Two absorbance peaks $\left(\lambda_{\max }\right)$ for Photobactin were predicted to be seen at $274 \mathrm{~nm}$ and $282 \mathrm{~nm}$. In the literature, it was reported at $257 \mathrm{~nm}$ and $316 \mathrm{~nm} .{ }^{12}$ The absorbance peaks $\left(\lambda_{\max }\right)$ were identical to Agrobactin under acidic conditions, which is expected due to the presence of an oxazoline ring. ${ }^{13,14}$ For Vibriobactin, it had a broad band at $320 \mathrm{~nm}$ and a sharper more intense band at 258 $\mathrm{nm} .{ }^{7}$ The greater absorbance in Vibriobactin is due to the fact it has two oxazoline rings while Agrobactin and Photobactin only have one. 


\section{Conclusion and Future Work}

The goal of this thesis was to synthesize Photobactin and study its binding properties with $\mathrm{Fe}^{3+}$. From the proposed synthesis (Scheme 6), which was inspired by Miller et al. and Takeuchi et al. one of the steps halted the synthesis of Photobactin. Specifically, the deprotection of the ester from the first building block has been troublesome, and hence the total synthesis of Photobactin has not been accomplished (Scheme 27). Once the ester group is cleaved, a coupling reagent can be used to couple the two building blocks together (Scheme 27 (a) and (b)), which will result in a protected Photobactin (Scheme 27 (c)). The final stage would be deprotection of the methoxy groups with $\mathrm{BBr}_{3}$; this method worked, by studying the deprotection of compound 13 (Scheme 22). Following these steps can lead to a successful synthesis of Photobactin.

Moreover, the binding studies of Photobactin were performed by computation calculations (DFT) using Spartan'10 and based on the results, a potential Fe-Photobactin complex can be a distorted square planar or an octahedral conformation where nitrogen from the oxazoline participates as a coordinating ligand. The octahedral conformation, is preferred based on the energy of the molecule (Figure 2.11.2).

Future work for a continuation from this thesis project involves increasing the yield of the amides

3 and 4. Using acyl chloride in this condensation reactions gave higher yields than when using the coupling reagent, EDC. $\mathrm{HCl}$, but exploring different coupling reagents may provide an even higher yield than the acyl chloride. Some recommended amide coupling reagents are DMTMM and HBTU. The other step is deprotecting the ester, which can be accomplished by using different acid base reactions (saponification) under different conditions for the methyl ester or choosing a new protecting group besides benzyl or methyl group. Deprotecting the benzyl group can be performed using a different hydrogen source, such as ammonium formate, in the presence of the catalyst palladium on carbon. Another way to cleave benzyl group is conducting the experiment 
under higher pressure using a Parr reactor, which will be explored in subsequent studies of these systems.
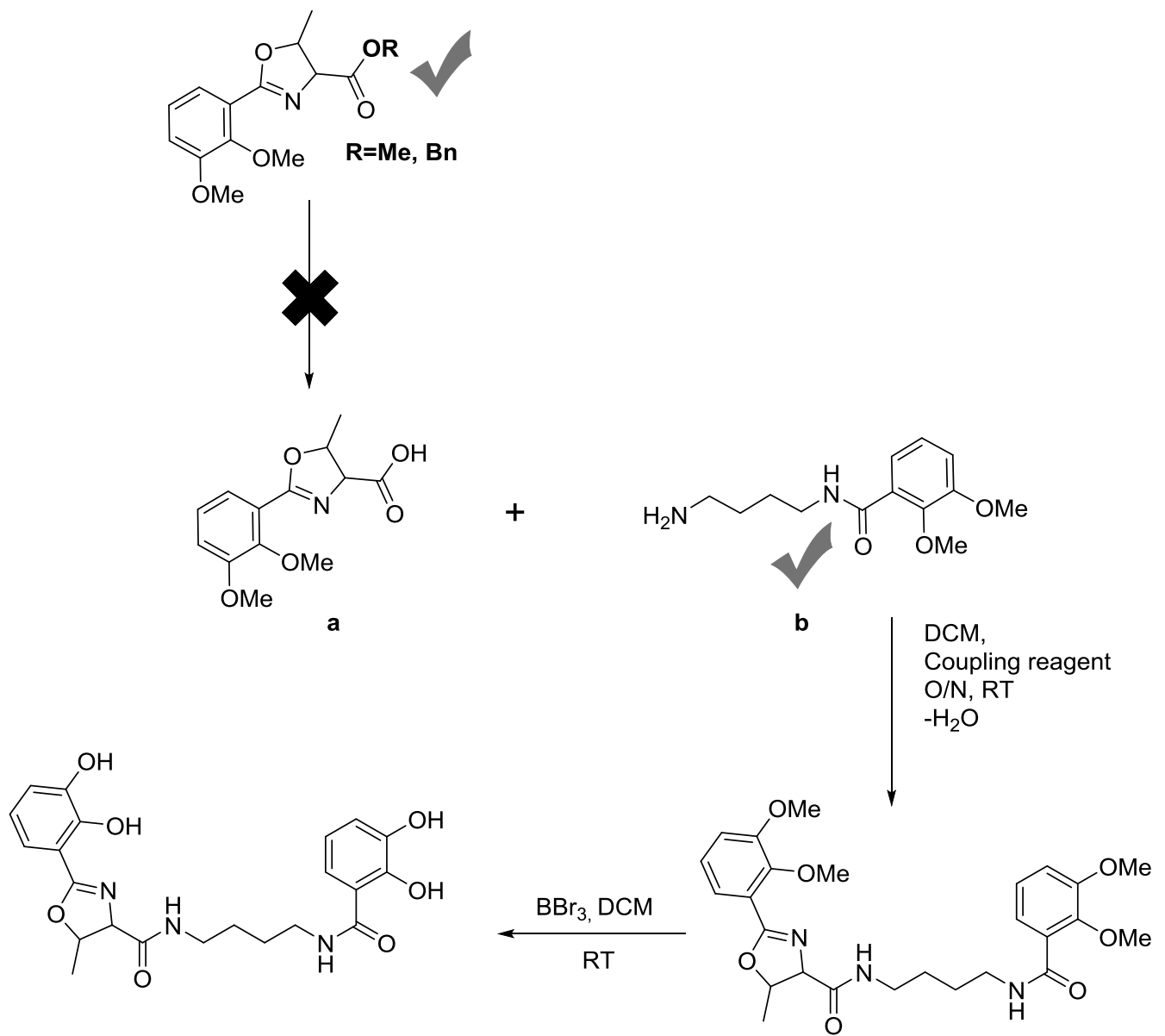

C

Scheme 27: The results from proposed synthesis of Photobactin

In conclusion, many experiments and studies have been completed on this siderophore, Photobactin. Even though this compound has not been successfully synthesized there is still potential that it will be synthesized, and hopefully in the near future Fe-Photobactin complex will be used as an application in medical sciences.

"There is no such thing as a failed experiment, only experiments with unexpected outcomes" -R. Buckminster Fuller 


\section{Experimental}

\section{General Section}

All reactions were carried out using standard bench top laboratory techniques. Reagents were purchased from Sigma Aldrich Chemical Co. and were used as received. The $\mathrm{R}_{f}$ values quoted were for thin layer chromatography (TLC) on Aldrich TLC plates, silica gel on aluminum. Silica gel 60 (particle size $0.063-0.200 \mathrm{~mm}$ ) was used as conventional preparative dry column vacuum chromatography. Approximately $75 \%$ of the cylindrical sintered glass funnel was filled with silica gel and then tapped to give an even distribution of silica. The glass funnel was placed in a vacuum (Büchner) flask and vacuum was applied. While preparing the column, the compound mixture was pre-adsorbed on silica gel. The mixture was dissolved in a small volume of DCM, and silica was added till it became a slurry mixture. To obtain separation it was required to apply the sample on the column as a thin layer. The filter paper was then placed on top of the compound. The column is developed by gradient elution using hexanes and EtOAc under vacuum. The least polar solvent mixture was added first (100\% hexanes) followed by solvent fractions of increasing polarity (0-100\% of EtOAc) in hexanes for elution.

When there was less than $200 \mathrm{mg}$ of crude compound, purification was done using preparative thin layer chromatography (Prep TLC, Fluka-Silica gel on TLC plates). Prep TLC was also done when further purification was needed after flash chromatography was performed on the compound and was used for separation of milligram quantities of materials. Once spotted and the plate was developed (hexanes-EtOAc), the materials were separated as long streaks rather than spots. The specific components were scraped off the plate along with the absorbent. Each separate component was then extracted from the stationary phase with a polar solvent (DCM or $\mathrm{MeOH})$

Proton $\left({ }^{1} \mathrm{H}-\mathrm{NMR}\right)$ and Carbon $\left({ }^{13} \mathrm{C}-\mathrm{NMR}\right)$ Nuclear Magnetic Resonance spectra were recorded on Bruker Avance II-400 spectrometer at $400 \mathrm{MHz}$ and $100 \mathrm{MHz}$ respectively using standard 
pulse sequences. Majority of the spectra were recorded in deuterated chloroform $\left(\mathrm{CDCl}_{3}\right)$ in 5 mm NMR tubes. The other spectra were recorded in deuterated methanol $\left(C D_{3} O D\right)$ and deuterium oxide $\left(\mathrm{D}_{2} \mathrm{O}\right)$. Homonuclear and heternoculear 2D-NMR (COSY, HSQC, and HMBC) experiments were recorded for some compounds, which assisted in assigning chemical shifts. UV-Vis absorption spectra were recorded on Perkin Elmer UV/Vis Spectrometer Lambda 20. Elemental analysis was performed by the Atlantic Microlab, Inc. in Norcoss Georgia, and it was analyzed for carbon $(\mathrm{C})$, hydrogen $(\mathrm{H})$, and nitrogen $(\mathrm{N})$ only. 
<smiles>COC(=O)C(N)C(C)O</smiles>

$\cdot \mathrm{HCl}$

Molecular Weight: $169.61 \mathrm{~g} / \mathrm{mol}$

\section{L-Threonine Methyl Ester Hydrochloride (1)}

L-Threonine (1.66 g, $13.94 \mathrm{mmol}$ ) was placed in a round bottom flask and chlorotrimethylsilane (3.53 $\mathrm{mL}, 27.80 \mathrm{mmol})$ was added slowly and stirred with a magnetic stirrer. Methanol $(20 \mathrm{~mL})$ was then added and the resulting solution was stirred $\mathrm{O} / \mathrm{N}$ at $\mathrm{RT}$ under $\mathrm{N}_{2}$. Then the reaction

mixture was concentrated on a rotary evaporator to give a yellowish-orange coloured oil as the title product.

$\mathrm{R}_{f}=<0.01$ (hexanes-EtOAc, 1:3); ${ }^{1} \mathrm{H}-\mathrm{NMR}\left(\mathrm{D}_{2} \mathrm{O}, 400 \mathrm{MHz}\right) \delta 4.43\left(\mathrm{qd},{ }^{3} J_{1}=6.60 \mathrm{~Hz},{ }^{3} J_{2}=3.80\right.$ $\mathrm{Hz}, 1 \mathrm{H}, \mathrm{CH}), 4.09\left(\mathrm{~d},{ }^{3} \mathrm{~J}=3.80 \mathrm{~Hz}, 1 \mathrm{H}, \mathrm{CH}\right), 3.87\left(\mathrm{~s}, 3 \mathrm{H}, \mathrm{OCH}_{3}\right), 1.34\left(\mathrm{~d},{ }^{3} \mathrm{~J}=6.60 \mathrm{~Hz}, 3 \mathrm{H}\right.$, $\left.\mathrm{CH}_{3}\right) ;{ }^{13} \mathrm{C}-\mathrm{NMR}\left(\mathrm{D}_{2} \mathrm{O}, 100 \mathrm{MHz}\right) \delta 65.37(\mathrm{CH}), 58.42(\mathrm{CH}), 53.60\left(\mathrm{OCH}_{3}\right), 18.71\left(\mathrm{CH}_{3}\right)$. 
<smiles>CC(O)C(N)C(=O)OCc1ccccc1</smiles>

Molecular Weight: $209.24 \mathrm{~g} / \mathrm{mol}$

\section{L-Threonine Benzyl Ester (2)}

In a $125 \mathrm{~mL}$ round bottom flask, L-Threonine $(1.78 \mathrm{~g}, 14.9 \mathrm{mmol})$, and p-toluene sulfonic acid monohydrate $(3.14 \mathrm{~g}, 16.5 \mathrm{mmol})$ were added with $25 \mathrm{~mL}$ of benzyl alcohol and $30 \mathrm{~mL}$ of benzene (or toluene). This reaction was refluxed for 24 hrs using a Dean Stark apparatus. Approximately $2 \mathrm{~mL}$ of water was collected. The yellow mixture was rotovapped to remove volatiles and was then partitioned between EtOAc $(20 \mathrm{~mL})$ and $\mathrm{H}_{2} \mathrm{O}(20 \mathrm{~mL})$. The organic layer was extracted two more times with $20 \mathrm{~mL}$ of $\mathrm{H}_{2} \mathrm{O}$. Then, $2.85 \mathrm{~g}(37.26 \mathrm{mmol})$ of $\mathrm{NaHCO}_{3}$ was added to the combined aqueous layer. In addition, the combined aqueous solution was extracted with EtOAc $(3 \times 20 \mathrm{~mL})$. The organic layers were combined and then dried over $\mathrm{MgSO}_{4}$, and filtered to give the crude product. The crude product was purified by flash chromatography in a $25 \mathrm{~mL}$ sintered glass funnel (elution with increasing amounts of EtOAc in hexanes). Benzyl alcohol eluted first (fractions 3-7). The product eluted when the column was flushed with EtOAc $\left(R_{f}=<0.01\right.$ (hexanes-EtOAC, 1:3)). The pure product following the evaporation of the solvent, was isolated as a yellow-coloured solid ( $0.62 \mathrm{~g}, 20 \%)$.

${ }^{1} \mathrm{H}-\mathrm{NMR}\left(\mathrm{CDCl}_{3}, 400 \mathrm{MHz}\right) \delta$ 7.39-7.37 (m, 5H, Ar-H), $5.20\left(\mathrm{~s}, 2 \mathrm{H}, \mathrm{CH}_{2}-\mathrm{Ar}\right), 3.94(\mathrm{~m}, 1 \mathrm{H}, \mathrm{CH}-$ $\mathrm{OH}$ ), $3.33\left(\mathrm{~d},{ }^{3} \mathrm{~J}=4.80 \mathrm{~Hz}, 1 \mathrm{H}, \mathrm{CH}-\mathrm{NH}_{2}\right), 2.37\left(\mathrm{~s}, 3 \mathrm{H}, \mathrm{OH}, \mathrm{NH}_{2}\right), 1.24\left(\mathrm{~d},{ }^{3} \mathrm{~J}=6.40 \mathrm{~Hz}, 3 \mathrm{H}, \mathrm{CH}_{3}\right.$ ); ${ }^{13} \mathrm{C}-\mathrm{NMR}\left(\mathrm{CDCl}_{3}, 100 \mathrm{MHz}\right) \delta 140.87(\mathrm{C}=\mathrm{O}), 128.59(\mathrm{ArCH}), 127.69(\mathrm{ArCH}), 127.65(\operatorname{ArCH})$, $127.00(\mathrm{ArCH}), 68.11(\mathrm{CH}-\mathrm{OH}), 65.42\left(\mathrm{CH}_{2}\right), 59.93\left(\mathrm{CH}-\mathrm{NH}_{2}\right), 19.79\left(\mathrm{CH}_{3}\right)$.

The ${ }^{1} \mathrm{H}-\mathrm{NMR}$ was identical to the reported values. ${ }^{18}$ 
<smiles>COc1cccc(C(=O)N[C@@H](C(C)=O)[C@@H](C)O)c1OC</smiles>

Molecular Weight: 297.31

\section{N-(o, m)-Dimethoxybenzoyl-L-Threonine methyl ester (3)}

In a $25 \mathrm{ml}$ round bottom flask, compound 1 (0.540 g, $1.04 \mathrm{mmol}), 2,3$-dimethoxybenzoic acid (0.580 g, $3.18 \mathrm{mmol})$, HOBt (0.050 g, $0.370 \mathrm{mmol})$, and $\mathrm{Et}_{3} \mathrm{~N}(0.44 \mathrm{~mL}, 3.15 \mathrm{mmol})$ was added with approximately $10 \mathrm{~mL}$ of DCM. The mixture was stirred for $2 \mathrm{~min}$ and $\mathrm{EDC} \cdot \mathrm{HCl}(0.68 \mathrm{~g}$, $1.82 \mathrm{mmol}$ ) was added to the mixture at $0^{\circ} \mathrm{C}$. The reaction mixture was stirred overnight under $\mathrm{N}_{2}$ at $\mathrm{RT}$. The reaction mixture was then washed with $\mathrm{H}_{2} \mathrm{O}(10 \mathrm{~mL}), 0.5 \mathrm{~N} \mathrm{HCl}(10 \mathrm{~mL}), 5 \%$ $\mathrm{Na}_{2} \mathrm{CO}_{3}$ solution $(10 \mathrm{~mL})$, and then brine $(10 \mathrm{~mL})$. The organic layer was then dried over $\mathrm{MgSO}_{4}$, filtered, and left to evaporate in a small beaker to yield a yellow coloured oil as the product $(0.077 \mathrm{~g}, 25 \%)$.

$\mathrm{R}_{f}=0.78$ (hexanes-EtOAc, $\left.1: 3\right) ;{ }^{1} \mathrm{H}-\mathrm{NMR}\left(\mathrm{CDCl}_{3}, 400 \mathrm{MHz}\right) \delta 8.89\left(\mathrm{~d},{ }^{3} \mathrm{~J}=8.50 \mathrm{~Hz}, 1 \mathrm{H}, \mathrm{OH}\right)$, $7.65\left(\mathrm{~d},{ }^{3} \mathrm{~J}=7.90 \mathrm{~Hz}, 1 \mathrm{H}, \operatorname{ArCH}\right), 7.11\left(\mathrm{dd},{ }^{3} J_{1}=7.90 \mathrm{~Hz},{ }^{3} J_{2}=8.10 \mathrm{~Hz}, 1 \mathrm{H}, \operatorname{ArCH}\right), 7.04\left(\mathrm{~d},{ }^{3} \mathrm{~J}=\right.$ $8.10 \mathrm{~Hz}, 1 \mathrm{H}, \mathrm{ArCH}), 4.78\left(\mathrm{dd},{ }^{3} J_{1}=8.50 \mathrm{~Hz},{ }^{3} J_{2}=2.50 \mathrm{~Hz}, 1 \mathrm{H}, \mathrm{CH}\right), 4.30\left(\mathrm{qd},{ }^{3} J_{1}=6.30 \mathrm{~Hz},{ }^{3} J_{2}=\right.$

$2.50 \mathrm{~Hz}, 1 \mathrm{H}, \mathrm{CH}), 3.95\left(\mathrm{~s}, 3 \mathrm{H}, \mathrm{CH}_{3}\right), 3.87\left(\mathrm{~s}, 3 \mathrm{H}, \mathrm{CH}_{3}\right), 3.74\left(\mathrm{~s}, 3 \mathrm{H}, \mathrm{CH}_{3}\right), 1.24\left(\mathrm{~d},{ }^{3} \mathrm{~J}=6.30 \mathrm{~Hz}\right.$, $\left.3 \mathrm{H}, \mathrm{CH}_{3}\right)$.

The ${ }^{1} \mathrm{H}-\mathrm{NMR}$ was identical to the reported values. ${ }^{20}$ 
<smiles>COc1cccc(C(=O)NC(C(C)=O)[C@@H](C)O)c1OC</smiles>

Molecular Weight: 297.31

\section{$\mathrm{N}$-(o, m)-Dimethoxybenzoyl-L-Threonine methyl ester (3)}

In a $25 \mathrm{~mL}$ round bottom flask 2,3-dimethoxybenzoic acid $(0.60 \mathrm{~g}, 3.24 \mathrm{mmol})$ was added with $\mathrm{DCM}(5 \mathrm{~mL})$ and $\mathrm{Et}_{3} \mathrm{~N}(0.70 \mathrm{~mL}, 4.86 \mathrm{mmol})$. Thionyl chloride $(0.24 \mathrm{~mL}, 3.24 \mathrm{mmol})$ was added last at $0{ }^{\circ} \mathrm{C}$ and the reaction mixture was stirred for $30 \mathrm{~min}$ at the same temperature under $\mathrm{N}_{2}$. Compound 1 (0.55 g, $3.24 \mathrm{mmol}$ ) was then added and the mixture was stirred $\mathrm{O} / \mathrm{N}$ under $\mathrm{N}_{2}$. The reaction mixture was washed with saturated $\mathrm{NaHCO}_{3}$ solution $(2 \times 5 \mathrm{~mL})$ and then with water $(2 \times 5 \mathrm{~mL})$. The organic layer was dried over $\mathrm{MgSO}_{4}$, filtered, and concentrated in vacuo which gave a brown coloured oil as the crude product. The residue was purified by flash column chromatography in a $25 \mathrm{~mL}$ sintered glass funnel (eluted with increasing amounts of EtOAc in hexanes; fractions $10-15)$ on silica gel afforded the title compound $(0.28 \mathrm{~g}, 29 \%)$ as a white solid.

$\mathrm{R}_{f}=0.78$ (hexanes-EtOAc,1:3); ${ }^{1} \mathrm{H}-\mathrm{NMR}\left(\mathrm{CDCl}_{3}, 400 \mathrm{MHz}\right) \delta 8.88\left(\mathrm{~d},{ }^{3} \mathrm{~J}=8.40 \mathrm{~Hz}, 1 \mathrm{H}, \mathrm{NH}\right)$, $7.65\left(\mathrm{~d},{ }^{3} \mathrm{~J}=7.90 \mathrm{~Hz}, 1 \mathrm{H}, \mathrm{Ar}-\mathrm{H}\right), 7.11\left(\mathrm{dd},{ }^{3} \mathrm{~J}_{1}=8.10 \mathrm{~Hz},{ }^{3} \mathrm{~J}_{2}=7.90 \mathrm{~Hz}, 1 \mathrm{H}, \mathrm{Ar}-\mathrm{H}\right), 7.04\left(\mathrm{~d},{ }^{3} \mathrm{~J}=\right.$ $8.10 \mathrm{~Hz}, 1 \mathrm{H}, \mathrm{Ar}-\mathrm{H}), 4.79\left(\mathrm{dd},{ }^{3} J_{1}=8.40 \mathrm{~Hz},{ }^{3} J_{2} 2.50 \mathrm{~Hz}, 1 \mathrm{H}, \mathrm{CH}\right), 4.38\left(\mathrm{qd},{ }^{3} J_{1}=6.30 \mathrm{~Hz},{ }^{3} J_{2}=\right.$ $2.50 \mathrm{~Hz}, 1 \mathrm{H}, \mathrm{CH}), 3.95\left(\mathrm{~s}, 3 \mathrm{H}, \mathrm{O}-\mathrm{CH}_{3}\right), 3.87\left(\mathrm{~s}, 3 \mathrm{H}, \mathrm{O}-\mathrm{CH}_{3}\right), 3.74\left(\mathrm{~s}, 3 \mathrm{H}, \mathrm{CH}_{3}\right), 1.24\left(\mathrm{~d},{ }^{3} \mathrm{~J}=6.30\right.$ $\left.\mathrm{Hz}, 3 \mathrm{H}, \mathrm{CH}_{3}\right) ;{ }^{13} \mathrm{C}-\mathrm{NMR}\left(\mathrm{CDCl}_{3}, 100 \mathrm{MHz}\right) \delta 171.70(\mathrm{C}=\mathrm{O}), 165.66(\mathrm{C}=\mathrm{O}), 152.75$ (ArC-OMe), $148.03(\mathrm{ArC}-\mathrm{OMe}), 125.88(\mathrm{ArC}-\mathrm{C}=\mathrm{O}), 124.37(\mathrm{ArC}-\mathrm{H}), 122.86(\mathrm{ArC}-\mathrm{H}), 115.84(\mathrm{ArC}-\mathrm{H}), 68.15$ $\left.(\mathrm{CH}), 61.67(\mathrm{CH}), 57.75\left(\mathrm{Ar}-\mathrm{OCH}_{3}\right), 56.14\left(\mathrm{Ar}-\mathrm{OCH}_{3}\right), 52.5(\mathrm{C}=\mathrm{O}-\mathrm{OCH})_{3}\right), 20.03\left(\mathrm{CH}_{3}\right)$.

The ${ }^{1} \mathrm{H}$ and ${ }^{13} \mathrm{C}$-NMR were identical to the reported values. ${ }^{20}$ 
<smiles>COc1cccc(C(=O)N[C@@H](C(=O)Oc2ccccc2)[C@@H](C)O)c1OC</smiles>

\section{Molecular Weight: $373.40 \mathrm{~g} / \mathrm{mol}$}

\section{N-(o,m)-Dimethoxybenzoyl-L-Threonine benzyl ester (4)}

In a $25 \mathrm{~mL}$ round bottom flask, compound 2 (0.218 g, $1.04 \mathrm{mmol}), 2,3$-dimethoxybenzoic acid (0.206 g, $1.13 \mathrm{mmol})$, HOBt $(0.0163 \mathrm{~g}, 0.121 \mathrm{mmol})$, and $\mathrm{Et}_{3} \mathrm{~N}(0.139 \mathrm{~mL}, 0.99 \mathrm{mmol})$ were combined together with $20 \mathrm{~mL}$ of DCM. The mixture was stirred for two min and then $\mathrm{EDC} \cdot \mathrm{HCl}$ $(0.199 \mathrm{~g}, 1.04 \mathrm{mmol})$ was added to the mixture at $0{ }^{\circ} \mathrm{C}$. The mixture was stirred $\mathrm{O} / \mathrm{N}$ at $\mathrm{RT}$ under $\mathrm{N}_{2}$. When the reaction was deemed to be complete (monitored by TLC) the reaction mixture was then partitioned between DCM $(10 \mathrm{~mL})$ and $\mathrm{H}_{2} \mathrm{O}(10 \mathrm{~mL})$. The organic layer was washed successively with $0.5 \mathrm{~N} \mathrm{HCl}(10 \mathrm{~mL}), 5 \% \mathrm{Na}_{2} \mathrm{CO}_{3}$ solution $(10 \mathrm{~mL})$, and then brine $(10$ $\mathrm{mL}$ ). The organic layer was then dried over $\mathrm{MgSO}_{4}$, filtered, and left to evaporate in a $25 \mathrm{~mL}$ beaker. The residue was purified by flash column chromatography in a $25 \mathrm{~mL}$ sintered glass funnel (eluted with $0-100 \%$ EtOAc in hexanes; fractions 8-13) on silica gel, affording the title compound $(0.128 \mathrm{~g}, 33 \%)$ as a yellowish-white coloured solid.

$\mathrm{R}_{f}=0.74$ (hexanes-EtOAc, 1:3) ; ${ }^{1} \mathrm{H}-\mathrm{NMR}\left(\mathrm{CDCl}_{3}, 400 \mathrm{MHz}\right) \delta 8.90(\mathrm{br} \mathrm{d}, 1 \mathrm{H}, \mathrm{NH}), 7.71\left(\mathrm{dd},{ }^{3} \mathrm{~J}_{1}\right.$ $\left.=7.90 \mathrm{~Hz},{ }^{3} J_{2}=1.60 \mathrm{~Hz}, 1 \mathrm{H}, \operatorname{Ar}-H\right), 7.35-7.32(\mathrm{~m}, 5 \mathrm{H}, \operatorname{Ar}-H), 7.18(\mathrm{t}, J=8.00 \mathrm{~Hz}, 1 \mathrm{H}, \operatorname{Ar}-H)$, $7.07\left(\mathrm{dd},{ }^{3} J_{1}=8.10 \mathrm{~Hz},{ }^{3} J_{2}=1.60 \mathrm{~Hz}, 1 \mathrm{H}, \mathrm{Ar}-\mathrm{H}\right), 5.23\left(\mathrm{~s}, 2 \mathrm{H}, \mathrm{CH}_{2}-\mathrm{Ar}\right), 4.88\left(\mathrm{dd},{ }^{3} J_{1}=8.50 \mathrm{~Hz}\right.$, $\left.{ }^{3} J_{2}=2.40 \mathrm{~Hz}, 1 \mathrm{H}, \mathrm{CH}-\mathrm{COO}_{2} \mathrm{Bn}\right), 4.43\left(\mathrm{qd},{ }^{3} \mathrm{~J}_{1}=6.40 \mathrm{~Hz},{ }^{3} \mathrm{~J}_{2}=2.40 \mathrm{~Hz}, 1 \mathrm{H}, \mathrm{CH}-\mathrm{OH}\right), 3.91(\mathrm{~s}$, $\left.6 \mathrm{H}, \operatorname{Ar}-\mathrm{OCH}_{3}\right), 1.27\left(\mathrm{~d},{ }^{3} \mathrm{~J}=6.40 \mathrm{~Hz}, 3 \mathrm{H}, \mathrm{CH}_{3}\right) ;{ }^{13} \mathrm{C}-\mathrm{NMR}\left(\mathrm{CDCl}_{3}, 100 \mathrm{MHz}\right) \delta 171.01(\mathrm{C}=\mathrm{O})$, $165.67(C=\mathrm{O}), 152.75$ (ArC-OMe), $148.06(\mathrm{ArC}-\mathrm{OMe}), 135.33\left(\mathrm{Ar} C-\mathrm{CH}_{2}\right), 128.29(\mathrm{Ar} C-\mathrm{C}=\mathrm{O})$, $128.43(\mathrm{ArCH}), 125.90(\mathrm{ArCH}), 124.89(\mathrm{ArCH}), 122.91(\mathrm{ArCH}), 115.84(\mathrm{ArCH}), \quad 68.27(\mathrm{CH})$, $67.29\left(\mathrm{CH}_{2}\right), 61.65(\mathrm{CH}), 57.81\left(\mathrm{O}-\mathrm{CH}_{3}\right), 56.15\left(\mathrm{O}-\mathrm{CH}_{3}\right), 20.11\left(\mathrm{CH}_{3}\right)$. 
<smiles>COc1cccc(C(=O)N[C@@H](C(=O)Oc2ccccc2)[C@@H](C)O)c1OC</smiles>

Molecular Weight: $373.40 .39 \mathrm{~g} / \mathrm{mol}$

\section{N-(o,m)-Dimethoxybenzoyl-L-Threonine benzyl ester (4)}

2,3-Dimethoxybenzoic acid $(0.0835 \mathrm{~g}, 0.459 \mathrm{mmol})$ and $\mathrm{Et}_{3} \mathrm{~N}(0.095 \mathrm{~mL}, 0.681 \mathrm{mmol})$ was added to DCM (7 mL) in a $25 \mathrm{~mL}$ round bottom flask. The stirring mixture was placed in an ice bath $\left(0^{\circ} \mathrm{C}\right)$ and thionyl chloride $(0.033 \mathrm{~mL}, 0.459 \mathrm{mmol})$ was added to the mixture stirring for 30 min. After, a solution of compound $2(0.096 \mathrm{~g}, 0.459 \mathrm{mmol})$ in DCM $(5 \mathrm{~mL})$ was added to the reaction flask at $0{ }^{\circ} \mathrm{C}$. After being stirred $\mathrm{O} / \mathrm{N}$ at $\mathrm{RT}$ under $\mathrm{N}_{2}$, the reaction mixture was diluted with $5 \mathrm{~mL}$ of $\mathrm{DCM}$ and was then extracted with $5 \% \mathrm{Na}_{2} \mathrm{CO}_{3}$ solution $(5 \mathrm{~mL})$, and water $(5 \mathrm{~mL})$. The organic layer was dried over $\mathrm{MgSO}_{4}$, filtered, and the evapouration of the solvent gave the title compound as a yellowish-brown coloured solid (0.094 g, 55\%).

$\mathrm{R}_{f}=0.76$ (hexanes-EtOAc, 1:1); ${ }^{1} \mathrm{H}-\mathrm{NMR}\left(\mathrm{CDCl}_{3}, 400 \mathrm{MHz}\right) \delta 8.90(\mathrm{~d}, J=8.50 \mathrm{~Hz}, 1 \mathrm{H}, \mathrm{NH})$, $7.71\left(\mathrm{dd},{ }^{3} J_{1}=7.90 \mathrm{~Hz},{ }^{3} \mathrm{~J}_{2}=1.60 \mathrm{~Hz}, 1 \mathrm{H}, \operatorname{Ar}-H\right), 7.35-7.32(\mathrm{~m}, 5 \mathrm{H}, \operatorname{Ar}-H), 7.18\left(\mathrm{t},{ }^{3} \mathrm{~J}=8.00 \mathrm{~Hz}\right.$, $1 \mathrm{H}, \operatorname{Ar}-H), 7.07\left(\mathrm{dd},{ }^{3} \mathrm{~J}_{1}=8.10 \mathrm{~Hz},{ }^{3} \mathrm{~J}_{2}=1.60 \mathrm{~Hz}, 1 \mathrm{H}, \mathrm{Ar}-H\right), 5.23\left(\mathrm{~s}, 2 \mathrm{H}, \mathrm{CH}_{2}-\mathrm{Ar}\right), 4.88\left(\mathrm{dd},{ }^{3} J_{1}=\right.$ $\left.8.50 \mathrm{~Hz},{ }^{3} J_{2}=2.40 \mathrm{~Hz}, 1 \mathrm{H}, \mathrm{CH}\right), 4.43\left(\mathrm{qd},{ }^{3} \mathrm{~J}_{1}=6.40 \mathrm{~Hz},{ }^{3} J_{2}=2.40 \mathrm{~Hz}, 1 \mathrm{H}, \mathrm{CH}\right), 3.91(\mathrm{~s}, 6 \mathrm{H}, \mathrm{O}-$ $\left.\mathrm{CH}_{3}\right) 1.26\left(\mathrm{~d},{ }^{3} \mathrm{~J}=6.40 \mathrm{~Hz}, 3 \mathrm{H}, \mathrm{CH}_{3}\right){ }^{13} \mathrm{C}-\mathrm{NMR}\left(\mathrm{CDCl}_{3}, 100 \mathrm{MHz}\right) \delta 171.01(\mathrm{C}=\mathrm{O}), 165.70$ $(\mathrm{C}=\mathrm{O}), 152.75(\mathrm{ArC}-\mathrm{OMe}), 148.06(\mathrm{ArC}-\mathrm{OMe}), 135.36\left(\mathrm{ArC}-\mathrm{CH}_{2}\right), 128.62(\mathrm{ArC}-\mathrm{C}=\mathrm{O}), 128.43$ $(\mathrm{ArCH}), 128.27(\mathrm{ArCH}) 125.90(\mathrm{ArCH}), 124.35(\mathrm{ArCH}), 122.88 \mathrm{ArCH}), 115.84(\mathrm{ArCH}), 68.27$ $(\mathrm{CH}), 67.26\left(\mathrm{CH}_{2}\right), 61.64(\mathrm{CH}), 57.90\left(\mathrm{O}-\mathrm{CH}_{3}\right), 56.14\left(\mathrm{O}-\mathrm{CH}_{3}, 20.11\left(\mathrm{CH}_{3}\right)\right.$. 
<smiles>COC(=O)C1N=C(c2cccc(OC)c2OC)O[C@@H]1C</smiles>

Molecular Weight: $279.29 \mathrm{~g} / \mathrm{mol}$

\section{(4S, 5R)-2-(o, m)-Dimethoxyphenyl)-5-methyl-4-oxazolinecarboxylic acid methyl ester (5)}

In a $10 \mathrm{~mL}$ round bottom flask, compound $3(0.07 \mathrm{~g}, 0.235 \mathrm{mmol}, 1$ eq) along with $\sim 5 \mathrm{~mL}$ of DCM was added and cooled to $-85{ }^{\circ} \mathrm{C}\left(\mathrm{EtOAC} / \mathrm{N}_{2}\right)$. Then (dimethylamino)sulfurtrifluoride (Methyl DAST; $0.0344 \mathrm{~mL}, 0.352 \mathrm{mmol}, 1.5 \mathrm{eq}$ ) was added to the reaction using a syringe. The reaction mixture was sealed with a septum and was stirred for one hour at $-85{ }^{\circ} \mathrm{C}$ under $\mathrm{N}_{2}$. After stirring for one hour, the septum was removed and anhydrous $\mathrm{K}_{2} \mathrm{CO}_{3}(0.05 \mathrm{~g}, 1.5 \mathrm{eq})$ was added. This allowed the reaction mixture to reach RT. After stirring for an additional hour, the mixture was washed with saturated $\mathrm{NaHCO}_{3}$ solution $(2 \times 10 \mathrm{~mL})$ and lastly with $\mathrm{H}_{2} \mathrm{O}(10 \mathrm{~mL})$. The organic layer was dried over $\mathrm{MgSO}_{4}$, filtered, and the evaporation of the solvent gave a yellow coloured oil as the crude product. Purification by flash chromatography using a $15 \mathrm{~mL}$ sintered glass funnel (increasing amounts of EtOAc in hexanes as the eluent; fractions 8-14) with silica gel afforded the title compound $(0.03 \mathrm{~g}, 46 \%)$ as a colourless solid.

$\mathrm{R}_{f}=0.32$ (hexanes-EtOAc, 1:1); ${ }^{1} \mathrm{H}-\mathrm{NMR}\left(\mathrm{CDCl}_{3}, 400 \mathrm{MHz}\right) \delta 7.36\left(\mathrm{~d},{ }^{3} \mathrm{~J}=7.50,1 \mathrm{H}, \mathrm{Ar}-\mathrm{H}\right)$, 7.07-7.03 (dd, $J_{1}=7.80 \mathrm{~Hz}, J_{2}=7.50 \mathrm{~Hz}, 2 \mathrm{H}, \mathrm{Ar}-H$ ), $5.06-5.03\left(\mathrm{qd},{ }^{3} J_{1}=6.20 \mathrm{~Hz},{ }^{3} J_{2}=2.20 \mathrm{~Hz}\right.$, $1 \mathrm{H}, \mathrm{CH}), 4.98\left(\mathrm{~d},{ }^{3} \mathrm{~J}=2.20 \mathrm{~Hz}, 1 \mathrm{H}, \mathrm{CH}\right), 3.87\left(\mathrm{~s}, 6 \mathrm{H}, \mathrm{OCH}_{3}\right), 3.77\left(\mathrm{~d},{ }^{3} \mathrm{~J}=2.30 \mathrm{~Hz}, 3 \mathrm{H}\right.$, $\left.\mathrm{COOCH}_{3}\right), 1.38\left(\mathrm{dd},{ }^{3} \mathrm{~J}_{1}=6.20 \mathrm{~Hz},{ }^{3} \mathrm{~J}_{2}=2.30 \mathrm{~Hz}, 3 \mathrm{H}, \mathrm{CH}_{3}\right) ;{ }^{13} \mathrm{C}-\mathrm{NMR}\left(\mathrm{CDCl}_{3}, 100 \mathrm{MHz}\right) \delta$ $170.44(C=\mathrm{O}), 165.39(C=\mathrm{N}), 153.43(\mathrm{Ar} C-\mathrm{OMe}), 149.03(\operatorname{Ar} C-\mathrm{OMe}), 123.88(\operatorname{Ar} C-\mathrm{C}=\mathrm{N}), 122.67$ $(\mathrm{ArCH}), 122.47(\mathrm{ArCH}) 115.57(\mathrm{ArCH}), 76.76(\mathrm{CH}), 71.72(\mathrm{CH}), 61.50\left(\mathrm{OCH}_{3}\right), 56.17\left(\mathrm{OCH}_{3}\right)$, $52.04\left(\mathrm{COOCH}_{3}\right), 16.13\left(\mathrm{CH}_{3}\right)$.

The ${ }^{1} \mathrm{H}$ and ${ }^{13} \mathrm{C}$-NMR were identical to the reported values. ${ }^{20}$ 
<smiles>COc1cccc(C2=N[C@H](C(=O)OCc3ccccc3)[C@@H](C)O2)c1OC</smiles>

Molecular Weight: $355.38 \mathrm{~g} / \mathrm{mol}$

(4S, 5R)-2-(o, m)-Dimethoxyphenyl)-5-methyl-4-oxazolinecarboxylic acid

benzyl ester (6)

In a $10 \mathrm{~mL}$ round bottom flask, compound 4 (0.01 g, $1 \mathrm{eq})$ was dissolved in $5 \mathrm{~mL}$ of DCM. The solution was stirred for $5 \mathrm{~min}$ at $-84^{\circ} \mathrm{C}$ (EtOAc and $\mathrm{N}_{2}$ ), then approximately $3 \mu \mathrm{L}(1.1 \mathrm{eq})$ of methyl DAST was added to the solution and the reaction was sealed with a septum and stirred for one hour at $-84{ }^{\circ} \mathrm{C}$ under $\mathrm{N}_{2}$. After one hour of stirring, the septum was removed and anhydrous $\mathrm{K}_{2} \mathrm{CO}_{3}(0.06 \mathrm{~g}, 1.5 \mathrm{eq})$ was added and the reaction mixture was allowed to reach RT. After stirring for another hour, the reaction mixture was partitioned between DCM (5 mL) and $\mathrm{H}_{2} \mathrm{O}(5 \mathrm{~mL})$. The organic layer was washed successively with saturated $\mathrm{NaHCO}_{3}$ solution $(2 \mathrm{X}$ $10 \mathrm{~mL}$ ) and lastly with water $(10 \mathrm{~mL})$. The organic layer was dried over $\mathrm{MgSO}_{4}$, filtered, and then left to evapourate. Purification by flash chromatography using a $15 \mathrm{~mL}$ sintered glass funnel (eluted with increasing amounts of EtOAc in hexanes; fractions 7-11) with silica gel afforded the title compound $(0.01 \mathrm{~g},>99 \%)$ as an oil.

$\mathrm{R}_{f}=0.60$ (hexanes-EtOAc, 1:3); ${ }^{1} \mathrm{H}-\mathrm{NMR}\left(\mathrm{CDCl}_{3}, 400 \mathrm{MHz}\right) \delta$ 7.37-7.32 (m, $\left.6 \mathrm{H}, \mathrm{Ar}-H\right)$ 7.09-7.02 (m, 2H, Ar-H), 5.22 (s, 2H, CHz-Ar), 5.04-4.99 (m, 2H, CH), 3.87 (s, 3H, OCH $), 3.86(\mathrm{~s}, 3 \mathrm{H}$, $\left.\mathrm{OCH}_{3}\right), 1.33\left(\mathrm{~d},{ }^{3} \mathrm{~J}=6.00 \mathrm{~Hz}, 3 \mathrm{H}, \mathrm{CH}_{3}\right) ;{ }^{13} \mathrm{C}-\mathrm{NMR}\left(\mathrm{CDCl}_{3}, 100 \mathrm{MHz}\right) \delta 169.79(\mathrm{C}=\mathrm{O}), 165.41$ $(\mathrm{C}=\mathrm{N}), 153.42(\mathrm{ArC}-\mathrm{OMe}), 148.92(\mathrm{ArC}-\mathrm{OMe}), 135.33\left(\mathrm{ArC}-\mathrm{CH}_{2}\right), 128.73(\operatorname{ArC}-\mathrm{C}=\mathrm{N}), 128.59$ $(\mathrm{ArCH}), 128.50(\mathrm{ArCH}) 123.87(\mathrm{ArCH}), 122.68(\mathrm{ArCH}), 122.44(\mathrm{ArCH}), 115.58(\mathrm{ArCH}), 77.55$ $\left(\mathrm{CH}-\mathrm{CH}_{3}\right), 71.67(\mathrm{CH}-\mathrm{C}=\mathrm{O}), 66.94\left(\mathrm{CH}_{2}\right), 61.50\left(\mathrm{O}-\mathrm{CH}_{3}\right), 56.18\left(\mathrm{O}-\mathrm{CH}_{3}\right), 16.10\left(\mathrm{CH}_{3}\right)$. 


\section{$\underset{\substack{1 \\ \text { Boc }}}{\mathrm{NH}_{2}}$ \\ Molecular Weight: $188.27 \mathrm{~g} / \mathrm{mol}$ \\ Boc-1, 4-diaminobutane (8)}

In a $25 \mathrm{~mL}$ round bottom flask 1,4-diaminobutane $(2 \mathrm{~mL}, 19.89 \mathrm{mmol})$ was dissolved in $\mathrm{CHCl}_{3}(\sim$ $10 \mathrm{~mL}$ ). Then a solution of $\mathrm{Boc}_{2} \mathrm{O}$ (di-tert-butyl dicarbonate; $1.16 \mathrm{~mL}, 5.05 \mathrm{mmol}$ ) in $5 \mathrm{~mL}$ of $\mathrm{CHCl}_{3}$ was added dropwise over a period of $30 \mathrm{~min}$ at $0{ }^{\circ} \mathrm{C}$. The reaction mixture was then stirred at RT for $24 \mathrm{hrs}$. The reaction mixture was partitioned between $\mathrm{CHCl}_{3}$ and $\mathrm{H}_{2} \mathrm{O}(15 \mathrm{~mL})$. The organic layer was washed with brine $(15 \mathrm{~mL})$ and dried over $\mathrm{MgSO}_{4}$, filtered, and concentrated in a $25 \mathrm{~mL}$ beaker. This resulted in a yellow coloured gooey liquid as the crude product $(2.00 \mathrm{~g}, 53 \%)$.

${ }^{1} \mathrm{H}-\mathrm{NMR}\left(\mathrm{CDCl}_{3}, 400 \mathrm{MHz}\right) \delta 4.79(\mathrm{br} \mathrm{s}, 1 \mathrm{H}, \mathrm{NH}), 3.05\left(\mathrm{~d}, J=6.10 \mathrm{~Hz}, 2 \mathrm{H}, \mathrm{CH}_{2}\right), 2.64(\mathrm{t}, J=$ $\left.6.50 \mathrm{~Hz}, 2 \mathrm{H}, \mathrm{CH}_{2}\right), 1.46-1.37\left(\mathrm{~m}, 15 \mathrm{H}, \mathrm{CH}_{3}, \mathrm{CH}_{2}, \mathrm{NH}_{2}\right)$.

The ${ }^{1} \mathrm{H}$-NMR was identical to the reported values. ${ }^{25}$ 
<smiles>COc1cccc(C(=O)NCCCCNC(=O)OCc2ccccc2)c1OC</smiles>

Molecular Weight: $352.43 \mathrm{~g} / \mathrm{mol}$

\section{N-Boc (1,4-aminobutyl)-2,3-(dimethoxyphenyl) benzamide (9)}

Compound $8(0.107 \mathrm{~mL}, 56 \mathrm{mmol})$ was placed in a round bottom flask along with $15 \mathrm{~mL}$ of DCM. 2,3-Dimethoxybenzoic acid $(0.101 \mathrm{~g}, 0.56 \mathrm{mmol})$, HOBt $(0.140 \mathrm{~g} 1.036 \mathrm{mmol})$, and Et ${ }_{3} \mathrm{~N}$ $(0.0685 \mathrm{~mL}, 0.49 \mathrm{mmol})$ were added after and stirred for couple of minutes at RT. EDC. $\mathrm{HCl}$ $(0.161 \mathrm{~g}, 0.840 \mathrm{mmol})$ was added last to the stirring mixture at $0{ }^{\circ} \mathrm{C}$. The mixture was stirred $\mathrm{O} / \mathrm{N}$ at $\mathrm{RT}$ under $\mathrm{N}_{2}$ then partitioned between $\mathrm{DCM}(10 \mathrm{~mL})$ and $\mathrm{H}_{2} \mathrm{O}(10 \mathrm{~mL})$. The organic layer was washed with saturated $\mathrm{NaHCO}_{3}$ solution $(10 \mathrm{~mL})$, and brine $(10 \mathrm{~mL})$. The organic layer was dried over $\mathrm{MgSO}_{4}$, filtered, and left to evaporate in a $25 \mathrm{~mL}$ beaker. The crude product was purified using flash chromatography on silica gel using a mixture of increasing amounts of EtOAc in hexanes (fractions 9-11). This gave a yellow coloured oil as the desired product $(0.049 \mathrm{~g}, 25 \%)$

$\mathrm{R}_{f}=0.77$ (hexanes-EtOAc, 1:3); ${ }^{1} \mathrm{H}-\mathrm{NMR}\left(\mathrm{CDCl}_{3}, 400 \mathrm{MHz}\right) \delta 7.99(\mathrm{br} \mathrm{s}, 1 \mathrm{H}, \mathrm{NH}), 7.67\left(\mathrm{dd},{ }^{3} \mathrm{~J}_{1}\right.$ $\left.=7.96 \mathrm{~Hz},{ }^{3} J_{2}=1.62 \mathrm{~Hz}, 1 \mathrm{H}, \mathrm{Ar}-\mathrm{H}\right), 7.14\left(\mathrm{dd},{ }^{3} J_{1}=9.60 \mathrm{~Hz},{ }^{3} J_{2}=6.501 \mathrm{H}, \mathrm{Ar}-\mathrm{H}\right), 7.03\left(\mathrm{dd},{ }^{3} J_{1}=\right.$ $\left.8.14 \mathrm{~Hz},{ }^{3} J_{2}=1.60 \mathrm{~Hz}, 1 \mathrm{H}, \mathrm{Ar}-\mathrm{H}\right), 4.61(\mathrm{br} \mathrm{s}, 1 \mathrm{H}, \mathrm{NH}), 3.89\left(\mathrm{~s}, 6 \mathrm{H}, \mathrm{O}-\mathrm{CH}_{3}\right), 3.47\left(\mathrm{dd},{ }^{3} J_{1}=12.68\right.$ $\left.\mathrm{Hz},{ }^{3} \mathrm{~J}_{2}=6.75 \mathrm{~Hz}, 2 \mathrm{H}, \mathrm{CH}_{2}\right), 3.18-3.15\left(\mathrm{~m}, 2 \mathrm{H}, \mathrm{CH}_{2}\right), 1.62\left(\mathrm{~m}, 4 \mathrm{H}, \mathrm{CH}_{2}\right), 1.42\left(\mathrm{~s}, 9 \mathrm{H}, \mathrm{CH}_{3}\right) ;{ }^{13} \mathrm{C}-$ $\operatorname{NMR}\left(\mathrm{CDCl}_{3}, 100 \mathrm{MHz}\right) \delta 165.21(\mathrm{C}=\mathrm{O}), 162.55(\mathrm{C}=\mathrm{O}), 152.55\left(\mathrm{ArC}-\mathrm{OCH}_{3}\right), 147.39(\operatorname{ArC}-$ $\left.\mathrm{OCH}_{3}\right), 126.84(\mathrm{ArC}-\mathrm{C}=\mathrm{O}), 124.44(\mathrm{ArCH}), 122.79(\mathrm{ArCH}), 115.26(\mathrm{ArCH}), 61.28\left(\mathrm{O}-\mathrm{CH}_{3}\right)$, 56.19 $\left(\mathrm{O}-\mathrm{CH}_{3}\right), 39.27\left(\mathrm{CH}_{2}\right), 33.71\left(\mathrm{CH}_{2}\right), 29.68\left(\mathrm{CH}_{3}\right), 27.62\left(\mathrm{CH}_{2}\right), 27.00\left(\mathrm{CH}_{2}\right)$. Anal. Calcd. For $\mathrm{C}_{18} \mathrm{H}_{28} \mathrm{~N}_{2} \mathrm{O}_{5}$ (\%): C 61.34, H 8.01, N 7.95; Found: C 61.62, H 8.07, N 6.54. 
<smiles>CC(C)(C)OC(=O)NCCCCNC(=O)c1cccc(OCc2ccccc2)c1OCc1ccccc1</smiles>

Molecular Weight: $504.63 \mathrm{~g} / \mathrm{mol}$

\section{N-Boc(1,4-aminobutyl)-[2,3-bis(benzyloxy)phenyl]benzamide (10)}

In a $25 \mathrm{~mL}$ round bottom flask, compound 8 (0.107 mL, $0.560 \mathrm{mmol})$, 2,3-bis(benzyloxy) benzoic acid $(0.18 \mathrm{~g}, 0.538 \mathrm{mmol})$, HOBt $(0.14 \mathrm{~g}, 1.04 \mathrm{mmol})$, and $15 \mathrm{~mL}$ of DCM was added and stirred for two min at RT. Then of EDC. $\mathrm{HCl}(0.16 \mathrm{~g}, 0.835 \mathrm{mmol})$ was added at $0{ }^{\circ} \mathrm{C}$. The reaction mixture was stirred $\mathrm{O} / \mathrm{N}$ at $\mathrm{RT}$ under $\mathrm{N}_{2}$. When the reaction was complete (monitored by TLC), the solution was washed with saturated $\mathrm{NaHCO}_{3}$ solution $(10 \mathrm{~mL}), \mathrm{H}_{2} \mathrm{O}(10 \mathrm{~mL})$, and brine $(10 \mathrm{~mL})$. The organic layer was dried over $\mathrm{MgSO}_{4}$, filtered, and concentrated in vacuo. Purification by flash chromatography (eluted with $0-100 \%$ of EtOAc in hexanes) on silica gel provided with the title compound (fractions $8-9,0.11 \mathrm{~g}, 40 \%$ ) as a yellow coloured solid.

$\mathrm{R}_{f}=0.56$ (hexanes-EtOAc, 1:3); ${ }^{1} \mathrm{H}-\mathrm{NMR}\left(\mathrm{CDCl}_{3}, 400 \mathrm{MHz}\right) \delta 7.95(\mathrm{br} \mathrm{s}, 1 \mathrm{H}, \mathrm{NH}), 7.75-7.73(\mathrm{~m}$, $1 \mathrm{H}, \operatorname{Ar}-H), 7.49-7.36(\mathrm{~m}, 10 \mathrm{H}, \operatorname{Ar}-H), 7.16\left(\mathrm{dd}, J_{1}=6.80 \mathrm{~Hz}, J_{2}=2.70 \mathrm{~Hz}, 2 \mathrm{H}, \operatorname{Ar}-H\right), 5.16(\mathrm{~s}$, 2H, $\mathrm{CH}_{2}-\mathrm{Ar}$ ), 5.09 (s, 2H, $\mathrm{CH}_{2}-\mathrm{Ar}$ ), 4.44 (br s, $1 \mathrm{H}, \mathrm{NH}$ ), 3.27 (q, J = 6.80 Hz, 2H, CH $\left.=5.60 \mathrm{~Hz}, 2 \mathrm{H}, \mathrm{CH}_{2}\right), 1.44\left(\mathrm{~s}, 9 \mathrm{H}, \mathrm{CH}_{3}\right), 1.35(\mathrm{~m}, 4 \mathrm{H})$. Anal. Calcd. For $\mathrm{C}_{30} \mathrm{H}_{36} \mathrm{~N}_{2} \mathrm{O}_{5}(\%): \mathrm{C}$ 71.40, H 7.19, N 5.55; Found: C 71.52, H 7.32, N 4.11. 
<smiles>NCCCCNC(=O)c1cccc(OCc2ccccc2)c1OCc1ccccc1</smiles>

Molecular Weight: $404.51 \mathrm{~g} / \mathrm{mol}$

\section{1,4-Aminobutyl-[2,3-bis(benzyloxy)phenyl] benzamide (11)}

In a $10 \mathrm{~mL}$ round bottom flask, compound $10\left(2.5 \mathrm{mg}, 4.96 \times 10^{-3} \mathrm{mmol}\right)$ was dissolved in DCM $(0.25 \mathrm{~mL}, 1 \mathrm{eq})$. The reaction mixture was placed in an ice bath and TFA $(0.25 \mathrm{~mL}, 1 \mathrm{eq})$ was added dropwise. The reaction occurred immediately once TFA was added. The mixture was monitored by TLC. Once complete $6 \mathrm{~N} \mathrm{NaOH}(0.55 \mathrm{~mL}, 2.2 \mathrm{eq})$ was added to the mixture and then extraction was performed adding an extra $5 \mathrm{~mL}$ of DCM. The organic layer was washed with water $(5 \mathrm{~mL})$ and then brine $(5 \mathrm{~mL})$. The organic layer was dried over $\mathrm{MgSO}_{4}$, filtered, and left to evaporate in a $25 \mathrm{~mL}$ beaker. This afforded the white solid as the desired product (1.2 $\mathrm{mg}, 60 \%)$. 


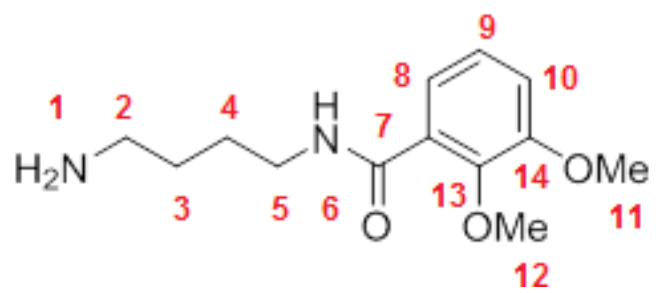

Molecular Weight: $252.31 \mathrm{~g} / \mathrm{mol}$

$\mathrm{N}$-(2,3-dimethoxybenzoyl)-1,4-diaminobutane (12)

1,4-Diaminobutane $(0.23 \mathrm{~mL}, 2.28 \mathrm{mmol})$ and 2,3-dimethoxybenzoic acid $(0.166 \mathrm{~g}, 0.911 \mathrm{mmol})$ were placed in a $25 \mathrm{~mL}$ round bottom flask with DCM $(\sim 15 \mathrm{~mL})$, and stirred for $10 \mathrm{~min}$. DMTMM $(0.630 \mathrm{~g}, 2.28 \mathrm{mmol})$ was then added to the mixture and it was stirred for approximately $19 \mathrm{hrs}$ at RT under $\mathrm{N}_{2}$. The crude product was washed with saturated $\mathrm{NaHCO}_{3}$ solution $(10 \mathrm{~mL})$, water $(10 \mathrm{~mL}), 0.5 \mathrm{~N} \mathrm{HCl}(10 \mathrm{~mL})$, water $(10 \mathrm{~mL})$, and then brine $(10 \mathrm{~mL})$. The organic layer was dried over $\mathrm{MgSO}_{4}$, filtered, and concentrated in vacuo to afford the product as a white solid. The crude product was purified using flash chromatography on silica gel eluting with EtOAc (fractions 2-7). The product isolated by flash chromatography was further purified by preparative TLC on a silica gel. Two bands (\#1 and \#2) were shown and were scraped off and dissolved with small amounts of methanol, filtered and left to evapourate. Both bands were characterized by ${ }^{1} \mathrm{H}-\mathrm{NMR}$. Band $\# 2$ had the desired product $(0.02 \mathrm{~g}, 9 \%)$ as a white solid.

${ }^{1} \mathrm{H}-\mathrm{NMR}\left(\mathrm{CDCl}_{3}, 400 \mathrm{MHz}\right) \delta 8.01(\mathrm{br} \mathrm{s}, 1 \mathrm{H}, \mathrm{NH}), 7.67(\mathrm{~d}, J=7.90 \mathrm{~Hz}, 1 \mathrm{H}, \mathrm{Ar}-H), 7.14\left(\mathrm{dd}, J_{1}=\right.$ $\left.8.10 \mathrm{~Hz}, J_{2}=7.90 \mathrm{~Hz}, 1 \mathrm{H}, \mathrm{Ar}-\mathrm{H}\right), 7.03(\mathrm{~d}, J=8.10 \mathrm{~Hz}, 1 \mathrm{H}, \operatorname{Ar}-H), 5.52(\mathrm{br} \mathrm{s}, 1 \mathrm{H}), 3.88(\mathrm{~d}, J=$ $\left.4.90 \mathrm{~Hz}, 6 \mathrm{H}, \mathrm{O}-\mathrm{CH}_{3}\right), 3.52-3.49\left(\mathrm{~m}, 3 \mathrm{H}, \mathrm{CH}_{2}\right), 1.73-1.66\left(\mathrm{~m}, 5 \mathrm{H}, \mathrm{CH}_{2}\right)$. 
<smiles>COc1cccc(C(=O)NCCCCNC(=O)c2cccc(OC)c2OC)c1OC</smiles>

Molecular Weight: $416.47 \mathrm{~g} / \mathrm{mol}$

\section{N,N'-Bis(2,3-bis(methoxy)benzoyl)-1,4 -diaminobutane (13)}

In a $25 \mathrm{~mL}$ round bottom flask, 2,3-dimethoxybenzoic acid $(0.084 \mathrm{~g}, 0.46 \mathrm{mmol})$ and $\mathrm{Et}_{3} \mathrm{~N}(0.096$ $\mathrm{mL}, 0.69 \mathrm{mmol}$ ) were added along with $3 \mathrm{~mL}$ of DCM. The reaction flask was placed in an ice bath and then thionyl chloride $(0.033 \mathrm{~mL}, 0.46 \mathrm{mmol})$ was added dropwise. The mixture was stirred for $30 \mathrm{~min}$ at RT under $\mathrm{N}_{2}$. 1,4-Diaminobutane $(0.092 \mathrm{~mL}, 0.92 \mathrm{mmol})$ was then added to the reaction mixture and continues stirring $\mathrm{O} / \mathrm{N}$ at $\mathrm{RT}$ under $\mathrm{N}_{2}$. Approximately $7 \mathrm{~mL}$ of $\mathrm{DCM}$ was added to the mixture and was washed with saturated $\mathrm{NaHCO}_{3}$ solution $(10 \mathrm{~mL})$ and then with $\mathrm{H}_{2} \mathrm{O}(10 \mathrm{~mL})$. The organic layer was dried over $\mathrm{MgSO}_{4}$, filtered, and the evapouration of the solvent afforded white crystals as the pure product (50 mg, $27 \%$ ).

$\mathrm{R}_{\mathrm{f}}=<0.01$ (hexanes-EtOAc, 1:1) ${ }^{1} \mathrm{H}-\mathrm{NMR}\left(\mathrm{CDCl}_{3}, 400 \mathrm{MHz}\right) \delta 8.00(\mathrm{~s}, 2 \mathrm{H}, \mathrm{NH}), 7.65\left(\mathrm{dd}, J_{1}=\right.$ $\left.7.90 \mathrm{~Hz}, J_{2}=1.00 \mathrm{~Hz}, 2 \mathrm{H}, \operatorname{Ar}-H\right), 7.12(\mathrm{t}, J=8.00 \mathrm{~Hz}, 2 \mathrm{H}, \operatorname{Ar}-H), 7.01\left(\mathrm{dd}, J_{1}=8.00 \mathrm{~Hz}, \mathcal{J}^{2}=\right.$ $1.00 \mathrm{~Hz}, 2 \mathrm{H}, \mathrm{Ar}-\mathrm{H}), 3.87\left(\mathrm{~s}, 12 \mathrm{H}, \mathrm{O}-\mathrm{CH}_{3}\right), 3.51-3.49\left(\mathrm{~m}, 4 \mathrm{H}, \mathrm{CH}_{2}-\mathrm{NH}\right)$ 1.72-171 (m, 4H, C-CHzC).

The ${ }^{1} \mathrm{H}-\mathrm{NMR}$ was identical to the reported values. ${ }^{30}$ 


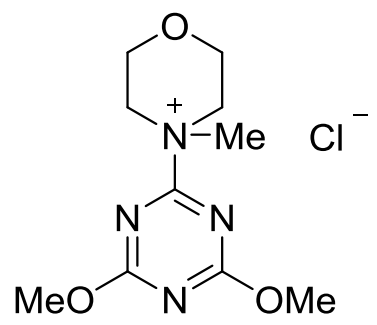

Molecular Weight: $276.12 \mathrm{~g} / \mathrm{mol}$

\section{4-(4,6-dimethoxy-1,3,5-triazin-2-yl)-4-methylmorpholinium chloride}

(DMTMM) (14)

In a $125 \mathrm{~mL}$ round bottom flask 2-chloro-4,6-dimethoxy-1,3,5-triazine (CDMT, $3.86 \mathrm{~g}, 22 \mathrm{mmol}$ ) was added into THF (60 mL). N-Methylmorpholine (NMM, $2.20 \mathrm{~mL}, 20 \mathrm{mmol})$ was slowly added into the stirring mixture and stirred for $30 \mathrm{~min}$; white precipitate was found. The organic material was then filtered by vacuum filtration to yield a white solid ( $5.42 \mathrm{~g}, 98 \%)$

${ }^{1} \mathrm{H}-\mathrm{NMR}\left(\mathrm{CD}_{3} \mathrm{OD}, 400 \mathrm{MHz}\right) \delta$ 4.52-4.55 (m, 2H, CH$), 4.18\left(\mathrm{~s}, 5 \mathrm{H}, \mathrm{O}-\mathrm{CH}_{3}\right), 4.08-4.06(\mathrm{~m}, 2 \mathrm{H}$, $\left.\mathrm{CH}_{2}\right)$, 3.89-3.83 (m, 4H, $\left.\mathrm{CH}_{2}\right), 3.51\left(\mathrm{~s}, 3 \mathrm{H}, \mathrm{N}-\mathrm{CH}_{3}\right)$.

The ${ }^{1} \mathrm{H}-\mathrm{NMR}$ was identical to the reported values. ${ }^{29}$ 
<smiles>O=C(NCCCCNC(=O)c1cccc(O)c1O)c1cccc(O)c1O</smiles>

Molecular Weight: $360.37 \mathrm{~g} / \mathrm{mol}$

\section{N,N'-Bis (2,3-dihydroxybenzoyl)-1-4-diaminobutane (15)}

In a $10 \mathrm{~mL}$ round bottom flask compound $13(0.03 \mathrm{~g}, 0.072 \mathrm{mmol})$ was added along with $2 \mathrm{~mL}$ of dry DCM. The reaction was sealed with a septum under $\mathrm{N}_{2}$. Then the reaction was placed in a $-84{ }^{\circ} \mathrm{C}$ bath and $\mathrm{BBr}_{3}$ was added $(0.100 \mathrm{~mL}, 1.053 \mathrm{mmol})$. The reaction immediately turned yellow from a colourless liquid upon the addition of $\mathrm{BBr}_{3}$. The reaction was stirred for $2 \mathrm{hrs}$ at $-84{ }^{\circ} \mathrm{C}$ and then at $\mathrm{RT}$ for $18 \mathrm{hrs}$. The reaction was then cooled to $-84{ }^{\circ} \mathrm{C}$ and anhydrous $\mathrm{MeOH}$ (0.7 mL), saturated $\mathrm{NaHCO}_{3}$ solution $(0.7 \mathrm{~mL})$, and then $\mathrm{H}_{2} \mathrm{O}(4 \mathrm{~mL})$ was added. The cooling bath was removed and allowed the reaction to reach room temperature. The septum was removed and extraction took place with EtOAc $(3 \times 10 \mathrm{~mL})$. The evapouration of the solvent in the aqueous layer afforded a whitish-grey coloured solid as the product $(0.02 \mathrm{~g}, 77 \%)$.

$\lambda_{\max }=318 \mathrm{~nm} ;{ }^{1} \mathrm{H}-\mathrm{NMR}\left(\mathrm{CD}_{3} \mathrm{OD}, 400 \mathrm{MHz}\right) \delta 8.87$ (br s, 2H, NH), 7.15-7.11 (m, 2H, Ar-H), 6.75$6.72(\mathrm{~m}, 2 \mathrm{H}, \operatorname{Ar}-H), 6.62\left(\mathrm{dd},{ }^{3} J_{1}=15.30 \mathrm{~Hz},{ }^{4} J_{2}=7.60 \mathrm{~Hz}, 2 \mathrm{H}, \operatorname{Ar}-H\right), 3.48-3.46(\mathrm{~m}, 4 \mathrm{H}, \mathrm{NH}-$ $\left.\mathrm{CH}_{2}\right), 1.73-1.71\left(\mathrm{~m}, 4 \mathrm{H}, \mathrm{C}-\mathrm{CH}_{2}-\mathrm{C}\right)$.

The ${ }^{1} \mathrm{H}-\mathrm{NMR}$ was identical to the reported values. ${ }^{30}$ 
<smiles>O=Cc1cccc(OCc2ccccc2)c1Br</smiles>

Molecular weight: $318.37 \mathrm{~g} / \mathrm{mol}$

\section{2,3-Dibenzyloxybenzaldehyde (16)}

In a $25 \mathrm{~mL}$ 3-neck round bottom flask, 2,3-dihydroxybenzaldehyde $(0.90 \mathrm{~g}, 6.52 \mathrm{mmol})$ was added along with benzyl chloride $(1.80 \mathrm{~mL}, 15.00 \mathrm{mmol})$ in $\mathrm{EtOH}(20 \mathrm{~mL})$. Lastly, $\mathrm{K}_{2} \mathrm{CO}_{3}(1.13$ $\mathrm{g}, 8.15 \mathrm{mmol}$ ) was added and the reaction mixture was refluxed for $20 \mathrm{hrs}$ in air. The reaction mixture was then pumped down and partitioned between EtOAc $(25 \mathrm{~mL})$ and $\mathrm{H}_{2} \mathrm{O}(25 \mathrm{~mL})$. The organic layer was dried over $\mathrm{MgSO}_{4}$, filtered, and the evapouration of the solvent gave a brownish-beige coloured solid as the title compound (0.65 g, 31\%).

${ }^{1} \mathrm{H}-\mathrm{NMR}\left(\mathrm{CDCl}_{3}, 400 \mathrm{MHz}\right) \delta 10.20(\mathrm{~s}, 1 \mathrm{H}, \mathrm{C}=\mathrm{OH}), 7.42-7.03(\mathrm{~m}, 13 \mathrm{H}, \mathrm{Ar}-\mathrm{H}), 5.13(\mathrm{~s}, 4 \mathrm{H}, \mathrm{CH})$. The ${ }^{1} \mathrm{H}-\mathrm{NMR}$ was identical to the reported values. ${ }^{34}$ 
<smiles>O=C(O)c1cccc(OCc2ccccc2)c1OCc1ccccc1</smiles>

Molecular Weight: $334.37 \mathrm{~g} / \mathrm{mol}$

\section{2,3-bis (benzyloxy) benzoic acid (17)}

In a $25 \mathrm{~mL}$ round bottom flask, 2,3-dibenzyloxybenzaldehyde $(0.57 \mathrm{~g}, 1.79 \mathrm{mmol})$ was dissolved in acetone $(5 \mathrm{~mL})$ and diluted with $\mathrm{H}_{2} \mathrm{O}(5 \mathrm{~mL})$. While stirring, sulfamic acid $(0.244 \mathrm{~g}, 2.51 \mathrm{mmol})$ and sodium chlorite $(0.170 \mathrm{~g}, 1.87 \mathrm{mmol})$ were added in a portion of $15 \mathrm{~min}$ to the opaque reaction mixture. The resulting solution was stirred for one hour at RT in air. Acetone was evapourated which yielded the product as a precipitate in the remaining aqueous mixture. The mixture was filtered and the crude was collected from the filter paper as a light brown coloured solid $(0.50 \mathrm{~g}, 84 \%)$ as the product.

$\mathrm{R}_{f}=0.74$ (hexanes-EtOAc, $\left.1: 3\right) ;{ }^{1} \mathrm{H}-\mathrm{NMR}\left(\mathrm{CDCl}_{3}, 400 \mathrm{MHz}\right) \delta 10.26(\mathrm{~s}, 1 \mathrm{H}, \mathrm{OH}), 7.76-7.19(\mathrm{~m}$, 13H, Ar- $H$ ), 5.27 (s, 2H, CH$\left.)_{2}\right), 5.19\left(\mathrm{~s}, 2 \mathrm{H}, \mathrm{CH}_{2}\right)$.

The ${ }^{1} \mathrm{H}$-NMR was identical to the reported values. ${ }^{34}$ 
<smiles>O=C(O)c1cccc(OCc2ccccc2)c1Br</smiles>

Molecular Weight: $334.37 \mathrm{~g} / \mathrm{mol}$

\section{2,3-bis (benzyloxy) benzoic acid (17)}

2,3-Bis(benzyloxy)benzoate $(2.00 \mathrm{~g}, 4.71 \mathrm{mmol})$ was added to $12 \%(\mathrm{w} / \mathrm{v}) \mathrm{K}_{2} \mathrm{CO}_{3}(\sim 16 \mathrm{~mL})$ in $\mathrm{MeOH}$ and heated under reflux in air for $20 \mathrm{hrs}$. The reaction stopped and water $(3 \mathrm{~mL})$ was added. Then cold concentrated $\mathrm{HCl}$ was added dropwise to the mixture until it reached $\mathrm{pH} 2$. Peachy coloured solid precipitated out of the mixture, reaction flask was placed in the freezer for a couple of hrs. The solid compound was then filtered and recrystallized with $95 \%$ ethanol to afford the product as brownish-peach coloured crystals $(1.07 \mathrm{~g}, 68 \%)$.

$\mathrm{R}_{f}=0.74$ (hexanes-EtOAc, 1:3); ${ }^{1} \mathrm{H}-\mathrm{NMR}\left(\mathrm{CDCl}_{3}, 400 \mathrm{MHz}\right) \delta 11.33(\mathrm{~s}, 1 \mathrm{H}, \mathrm{OH}), 7.76\left(\mathrm{dd}, \mathrm{J}_{1}=\right.$ $\left.7.90 \mathrm{~Hz}, J_{2}=1.70 \mathrm{~Hz}, 1 \mathrm{H}, \operatorname{Ar}-H\right), 7.53-7.21(\mathrm{~m}, 12 \mathrm{H}, \mathrm{Ar}-H), 5.28\left(\mathrm{~s}, 2 \mathrm{H}, \mathrm{CH}_{2}\right), 5.21(\mathrm{~s}, 2 \mathrm{H}, \mathrm{CH})_{2}$. 
<smiles>NC(=O)c1cccc(OCc2ccccc2)c1OCc1ccccc1</smiles>

Molecular Weight: $333.39 \mathrm{~g} / \mathrm{mol}$

\section{2,3-bis(benzyloxy)benzamide (18)}

In a $50 \mathrm{~mL}$ round bottom flask, 2,3-dibenzyloxybenzoic acid $(0.30 \mathrm{~g}, 0.89 \mathrm{mmol})$, DCM $(20 \mathrm{~mL})$ and $\mathrm{Et}_{3} \mathrm{~N}(0.188 \mathrm{~mL}, 1.35 \mathrm{mmol})$ were added. At $0{ }^{\circ} \mathrm{C}$, thionyl chloride $(0.065 \mathrm{~mL}, 1.35 \mathrm{mmol})$ was added to the stirring mixture which was continued stirring for 30 min under the same condition. Lastly, concentrated $\mathrm{NH}_{4} \mathrm{OH}(2.2 \mathrm{~mL})$ was added slowly at $0{ }^{\circ} \mathrm{C}$, and continued stirring for 24 hrs at RT under $\mathrm{N}_{2}$. The reaction mixture was then partitioned between DCM (15 $\mathrm{mL}$ ) and $\mathrm{H}_{2} \mathrm{O}(15 \mathrm{~mL})$. The organic layer was washed with $5 \% \mathrm{Na}_{2} \mathrm{CO}_{3}(15 \mathrm{~mL})$ and then water $(15 \mathrm{~mL})$. The organic layer was then dried over $\mathrm{MgSO}_{4}$, filtered, and concentrated to yield the crude product as a brown coloured solid. Recrystallization with $50 \%$ aqueous EtOH gave a white solid as the pure product $(0.130 \mathrm{~g}, 44 \%)$.

${ }^{1} \mathrm{H}-\mathrm{NMR}\left(\mathrm{CDCl}_{3}, 400 \mathrm{MHz}\right) \delta 7.81(\mathrm{br} \mathrm{s}, 1 \mathrm{H}, \mathrm{NH}), 7.75-7.72(\mathrm{~m}, 1 \mathrm{H}, \mathrm{Ar}-H), 7.48-7.32(\mathrm{~m}, 10 \mathrm{H}$, $\operatorname{Ar}-H)$, 7.17-7.16 (m, 2H, Ar- $H$ ), $5.16\left(\mathrm{~s}, 2 \mathrm{H}, \mathrm{CH}_{2}\right), 5.09\left(\mathrm{~s}, 2 \mathrm{H}, \mathrm{CH}_{2}\right)$.

The ${ }^{1} \mathrm{H}-\mathrm{NMR}$ was identical to the reported values. ${ }^{33}$ 
<smiles>CCOC(=N)c1cccc(OCc2ccccc2)c1OCC</smiles>

Molecular Weight: $361.44 \mathrm{~g} / \mathrm{mol}$

\section{Ethyl-2,3-bis(benzyloxy)benzimidate (19)}

In a $5 \mathrm{~mL}$ round bottom flask, 2,3-bis(benzyloxy)benzamide $(0.01 \mathrm{~g}, 0.0299 \mathrm{mmol})$ and $1 \mathrm{~mL}$ of DCM were added. Then triethyloxonium hexafluorophosphate $(0.009 \mathrm{~g}, 0.0363 \mathrm{mmol})$ and another $1 \mathrm{~mL}$ of $\mathrm{DCM}$ were added. The reaction mixture was stirred $\mathrm{O} / \mathrm{N}$ at $\mathrm{RT}$ under $\mathrm{N}_{2}$. Once the reaction was completed (monitored by TLC), cold $1 \mathrm{M} \mathrm{Na} \mathrm{CO}_{3}(10 \mathrm{~mL}$ ) was poured into a separatory funnel along with the reaction mixture. This was then extracted. The aqueous layer was re-extracted with DCM $(2 \times 10 \mathrm{~mL})$ and the organic layer was dried over $\mathrm{MgSO}_{4}$, filtered, and concentrated in vacuo. Purification by flash chromatography using a $15 \mathrm{~mL}$ sintered glass funnel (eluted with increasing amounts of EtOAc in hexanes; fractions 2-3) with silica gel afforded the title compound (0.02 $\mathrm{g},>99 \%)$ as a clear oil.

$\mathrm{R}_{f}=0.90$ (hexanes-EtOAc, 1:1); ${ }^{1} \mathrm{H}-\mathrm{NMR}\left(\mathrm{CDCl}_{3}, 400 \mathrm{MHz}\right) \delta 7.45-7.26(\mathrm{~m}, 11 \mathrm{H}, \mathrm{Ar}-\mathrm{H}), 7.15-$ $7.06(\mathrm{~m}, 2 \mathrm{H}, \operatorname{Ar}-H), 5.13\left(\mathrm{~d}, J=9.10 \mathrm{~Hz}, 4 \mathrm{H}, \mathrm{CH}_{2}\right), 4.32\left(\mathrm{q}, J=7.10 \mathrm{~Hz}, 2 \mathrm{H}, \mathrm{CH}_{2}\right), 1.31(\mathrm{t}, J=$ $\left.7.10 \mathrm{~Hz}, 3 \mathrm{H}, \mathrm{CH}_{3}\right)$.

The ${ }^{1} \mathrm{H}-\mathrm{NMR}$ was identical to the reported values. ${ }^{33}$ 
<smiles>O=C(Oc1ccccc1)c1cccc(OCc2ccccc2)c1Br</smiles>

Molecular Weight: $424.50 \mathrm{~g} / \mathrm{mol}$

\section{Benzyl - 2,3-bis (benzyloxy) benzoate}

2,3-Dihydroxybenzoic acid (1.00 g, $6.49 \mathrm{mmol})$ was dissolved in acetone (50 mL). Anhydrous $\mathrm{K}_{2} \mathrm{CO}_{3}(4.03 \mathrm{~g}, 29.16 \mathrm{mmol})$ was added to the mixture and left to stir for $5 \mathrm{~min}$ at RT. Benzyl bromide (3.50 $\mathrm{mL}, 29.16 \mathrm{mmol})$ was added to the stirring mixture and then it was heated under reflux for $20 \mathrm{hrs}$ in air. The solvent was removed under reduced pressure affording the product as peach coloured solid (2.13 $\mathrm{g}, 77 \%)$.

${ }^{1} \mathrm{H}-\mathrm{NMR}\left(\mathrm{CDCl}_{3}, 400 \mathrm{MHz}\right)$ ठ 7.48-7.30 (m, 16H, Ar-H), $7.17(\mathrm{~d}, J=8.10 \mathrm{~Hz}, 1 \mathrm{H}, \mathrm{Ar}-\mathrm{H}), 7.12(\mathrm{t}$, $J=7.90 \mathrm{~Hz}, 1 \mathrm{H}, \mathrm{Ar}-\mathrm{H}), 5.36\left(\mathrm{~s}, 2 \mathrm{H}, \mathrm{CH}_{2}\right), 5.16\left(\mathrm{~s}, 2 \mathrm{H}, \mathrm{CH}_{2}\right), 5.12\left(\mathrm{~s}, 2 \mathrm{H}, \mathrm{CH}_{2}\right)$. 
<smiles>COC(=O)[C@H](CO)NC(=O)c1ccccc1OCc1ccccc1</smiles>

Molecular Weight: $329.35 \mathrm{~g} / \mathrm{mol}$

\section{N-[2-(benzyloxy)benzoyl]-L-Serine methyl ester (20)}

In a $50 \mathrm{~mL}$ round bottom flask, 2-(benzyloxy)benzoic acid $(1.00 \mathrm{~g}, 4.38 \mathrm{mmol})$ and L-serine methyl ester hydrochloride $(0.62 \mathrm{~g}, 3.96 \mathrm{mmol})$ was dissolved in $25 \mathrm{~mL}$ of $\mathrm{DCM} \mathrm{Et}_{3} \mathrm{~N}(0.59 \mathrm{~mL}$, $4.23 \mathrm{mmol})$ and $\mathrm{EDC} \cdot \mathrm{HCl}(0.84 \mathrm{~g}, 4.38 \mathrm{mmol})$ was added to the reaction mixture, sealed with a septum and stirred $\mathrm{O} / \mathrm{N}$ under $\mathrm{N}_{2}$. The reaction mixture was diluted with $\mathrm{DCM}(10 \mathrm{~mL})$ and washed with $\mathrm{H}_{2} \mathrm{O}$ (35 mL), $5 \% \mathrm{NaHCO}_{3}$ solution (35 mL), $5 \%$ citric acid solution $(35 \mathrm{~mL}), \mathrm{H}_{2} \mathrm{O}$ (35 mL), and brine (35 mL). The organic layer was dried over $\mathrm{MgSO}_{4}$, filtered, and concentrated in vacuo which gave a yellow coloured oil as the crude product. The crude product was then recrystallized with toluene which afforded the product $(0.39 \mathrm{~g}, 30 \%)$ as yellowish-white coloured crystals.

${ }^{1} \mathrm{H}-\mathrm{NMR}\left(\mathrm{CDCl}_{3}, 400 \mathrm{MHz}\right) \delta 8.74\left(\mathrm{~d},{ }^{3} \mathrm{~J}=6.90 \mathrm{~Hz}, 1 \mathrm{H}, \mathrm{NH}\right), 8.16\left(\mathrm{dd}, J_{1}=7.80, J_{2}=1.90 \mathrm{~Hz}\right.$, $1 \mathrm{H}, \operatorname{Ar}-H), 7.47-7.36(\mathrm{~m}, 6 \mathrm{H}, \mathrm{Ar}-H), 7.07-7.03(\mathrm{~m}, 2 \mathrm{H}, \mathrm{Ar}-H), 5.21(\mathrm{~d}, \mathrm{~J}=3.90 \mathrm{~Hz}, 2 \mathrm{H}, \mathrm{CH}), 4.82-$ $4.80(\mathrm{~m}, 1 \mathrm{H}, \mathrm{CH}), 3.89-3.84\left(\mathrm{~m}, 2 \mathrm{H}, \mathrm{CH}_{2}\right), 3.66\left(\mathrm{~s}, 3 \mathrm{H}, \mathrm{CH}_{3}\right)$. 
<smiles>COC(=O)[C@@H]1COC(c2ccccc2OCc2ccccc2)=N1</smiles>

Molecular Weight: $311.34 \mathrm{~g} / \mathrm{mol}$

(S)-Methyl 2-[2-Benzyloxy)phenyl]-1,3-oxazoline-4-carboxylate (21)

In a $10 \mathrm{~mL}$ round bottom flask, $N$-[2-(benzyloxy)benzoyl]-L-serine methyl ester (20) $(0.10 \mathrm{~g}, 0.30$ mmol) was dissolved in THF ( 5 mL) and Burgess reagent $(0.079 \mathrm{~g}, 0.33 \mathrm{mmol})$ was added. The reaction mixture was refluxed for 30 min under $\mathrm{N}_{2}$. The reaction was then diluted with EtOAc $(10 \mathrm{~mL})$ and washed with $\mathrm{H}_{2} \mathrm{O}(15 \mathrm{~mL})$ and then brine $(15 \mathrm{~mL})$. The organic layer was dried over $\mathrm{Mg}_{2} \mathrm{SO}_{4}$, filtered, and allowed to evaporate in a $50 \mathrm{~mL}$ beaker to yield a yellow coloured oil as the desired product (22) (0.056 g, 60\%).

No purifications were performed for this product.

${ }^{1} \mathrm{H}-\mathrm{NMR}\left(\mathrm{CDCl}_{3}, 400 \mathrm{MHz}\right) \delta 7.82\left(\mathrm{dd}, J_{1}=7.50 \mathrm{~Hz}, J_{2}=1.80 \mathrm{~Hz}, 1 \mathrm{H}, \mathrm{Ar}-\mathrm{H}\right), 7.53-7.31(\mathrm{~m}, 6 \mathrm{H}$, $\operatorname{Ar}-H$ ), $7.01\left(\mathrm{dd}, J_{1}=8.30 \mathrm{~Hz}, J_{2}=0.80 \mathrm{~Hz}, 2 \mathrm{H}, \operatorname{Ar}-H\right), 5.21\left(\mathrm{~s}, 2 \mathrm{H}, \mathrm{CH}\right.$ ), 4.99 (dd, ${ }^{3} J_{1}=10.60$ $\left.\mathrm{Hz},{ }^{3} J_{2}=8.10 \mathrm{~Hz}, 1 \mathrm{H}, \mathrm{CH}\right), 4.62-4.57\left(\mathrm{~m}, 2 \mathrm{H}, \mathrm{CH}_{2}\right), 3.83\left(\mathrm{~s}, 3 \mathrm{H}, \mathrm{CH}_{3}\right)$. 


\section{Appendix}

Figure A1.1: $\quad{ }^{1} \mathrm{H}$-NMR of L-Threonine Methyl Ester Hydrochloride (1) in $\mathrm{D}_{2} \mathrm{O}$

Figure A1.2: $\quad{ }^{13} \mathrm{C}-\mathrm{NMR}$ of L-Threonine Methyl Ester Hydrochloride (1) in $\mathrm{D}_{2} \mathrm{O} \quad 80$

Figure A1.3: $\quad{ }^{1} \mathrm{H}-\mathrm{NMR}$ of L-Threonine Benzyl Ester (2) in $\mathrm{CDCl}_{3}$

Figure A1.4: $\quad{ }^{13} \mathrm{C}-\mathrm{NMR}$ of L-Threonine Benzyl Ester (2) in $\mathrm{CDCl}_{3}$

Figure A1.5: $\quad{ }^{1} \mathrm{H}$-NMR of $\mathrm{N}-(\mathrm{o}, \mathrm{m})$-Dimethyloxybenzoyl-L-Threonine methyl ester $(\mathbf{3}) \quad 83$ in $\mathrm{CDCl}_{3}$

Figure A1.6: $\quad{ }^{13} \mathrm{C}-\mathrm{NMR}$ of $\mathrm{N}-(0, m)$-Dimethyloxybenzoyl-L-Threonine methyl ester $(\mathbf{3}) \quad 84$ in $\mathrm{CDCl}_{3}$

Figure A1.7: $\quad{ }^{1} \mathrm{H}-\mathrm{NMR}$ of $\mathrm{N}-(o, m)$-Dimethoxybenzoyl-L-Threonine benzyl ester (4) in 85 $\mathrm{CDCl}_{3}$

Figure A1.8: $\quad{ }^{13} \mathrm{C}-\mathrm{NMR}$ of $\mathrm{N}$-(o,m)-Dimethoxybenzoyl-L-Threonine benzyl ester (4) in $\quad 86$ $\mathrm{CDCl}_{3}$

Figure A1.9: $\quad{ }^{1} \mathrm{H}-\mathrm{NMR}((4 S, 5 R)-2-(o, m)$-Dimethoxyphenyl)-5-methyl-4oxazolinecarboxylic acid methyl ester (5) in $\mathrm{CDCl}_{3}$

Figure A1.10: ${ }^{13} \mathrm{C}-\mathrm{NMR}((4 S, 5 R)-2-(0, m)$-Dimethoxyphenyl)-5-methyl-4oxazolinecarboxylic acid methyl ester (5) in $\mathrm{CDCl}_{3}$

Figure A1.11: $\quad{ }^{1} \mathrm{H}-\mathrm{NMR}$ of $(4 S, 5 R)-2-(o, m)$-Dimethoxyphenyl)-5-methyl-4oxazolinecarboxylic acid benzyl ester (6) in $\mathrm{CDCl}_{3}$

Figure A1.12: ${ }^{13} \mathrm{C}-\mathrm{NMR}$ of $(4 S, 5 R)-2-(o, m)$-Dimethoxyphenyl)-5-methyl-4oxazolinecarboxylic acid benzyl ester (6) in $\mathrm{CDCl}_{3}$

Figure A1.13: ${ }^{1} \mathrm{H}-\mathrm{NMR}$ of Boc-1, 4-diaminobutane (8) in $\mathrm{CDCl}_{3}$

Figure A1.14: ${ }^{1} \mathrm{H}-\mathrm{NMR}$ of $\mathrm{N}$-Boc (1,4-aminobutyl)-2,3-(dimethoxyphenyl) benzamide (9) in $\mathrm{CDCl}_{3}$ 
Figure A1.15: ${ }^{13} \mathrm{C}-\mathrm{NMR}$ of $\mathrm{N}$-Boc (1,4-aminobutyl)-2,3-(dimethoxyphenyl) benzamide

(9) in $\mathrm{CDCl}_{3}$

Figure A1.16: $\quad{ }^{1} \mathrm{H}-\mathrm{NMR}$ of $\mathrm{N}$-Boc(1,4-aminobutyl)-[2,3-

bis(benzyloxy)phenyl]benzamide (10) in $\mathrm{CDCl}_{3}$

Figure A1.17: $\quad{ }^{1} \mathrm{H}-\mathrm{NMR}$ of $\mathrm{N}$-(2,3-dimethoxybenzoyl)-1,4-diaminobutane (12) in $\mathrm{CDCl}_{3} \quad 95$

Figure A1.18: $2 \mathrm{D}\left({ }^{1} \mathrm{H},{ }^{1} \mathrm{H}\right)-\mathrm{COSY}-N M R$ of $\mathrm{N}$-(2,3-dimethoxybenzoyl)-1,4diaminobutane (12) in $\mathrm{CDCl}_{3}$

Figure A1.19: $2 \mathrm{D}\left({ }^{1} \mathrm{H},{ }^{13} \mathrm{C}\right)-\mathrm{HSQC}-\mathrm{NMR}$ of $\mathrm{N}$-(2,3-dimethoxybenzoyl)-1,4diaminobutane (12) in $\mathrm{CDCl}_{3}$

Figure A1.20: $2 \mathrm{D}\left({ }^{1} \mathrm{H},{ }^{13} \mathrm{C}\right)-\mathrm{HMBC}-\mathrm{NMR}$ of $\mathrm{N}$-(2,3-dimethoxybenzoyl)-1,4diaminobutane (12) in $\mathrm{CDCl}_{3}$

Figure A1.21: ${ }^{1} \mathrm{H}-\mathrm{NMR}$ of $\mathrm{N}, \mathrm{N}$-Bis(2,3 -bis(methoxy)benzoyl)-1,4 -diaminobutane (13) in $\mathrm{CDCl}_{3}$

Figure A1.22: ${ }^{1} \mathrm{H}-\mathrm{NMR}$ of DMTMM (14) in $\mathrm{CD}_{3} \mathrm{OD} \quad 100$

Figure A1.23: $\quad{ }^{1} \mathrm{H}-\mathrm{NMR}$ of $\mathrm{N}$-Bis-(2,3-Dimethyoxybenzoyl)-1,4-diaminobutane (15) in 101 $\mathrm{CD}_{3} \mathrm{OD}$

Figure A1.24: ${ }^{1} \mathrm{H}-\mathrm{NMR}$ of 2, 3-Dibenzyloxybenzaldehyde (16) in $\mathrm{CDCl}_{3}$

Figure A1.25: $\quad{ }^{1} \mathrm{H}-\mathrm{NMR}$ of 2, 3-Bis (benzyloxy) benzoic acid (17) in $\mathrm{CDCl}_{3} \quad 103$

Figure A1.26: ${ }^{1} \mathrm{H}-\mathrm{NMR}$ of 2, 3-Bis (benzyloxy) benzamide (18) in $\mathrm{CDCl}_{3}$

Figure A1.27: $\quad{ }^{1} \mathrm{H}-\mathrm{NMR}$ of Ethyl-2, 3-Bis (benzyloxy) Benzimidate (19) in $\mathrm{CDCl}_{3} \quad 105$

Figure A1.28: ${ }^{1} \mathrm{H}-\mathrm{NMR}$ of Benzyl-2, 3-Bis (Benzyloxy) Benzoate in $\mathrm{CDCl}_{3} \quad 106$

Figure A1.29: $\quad{ }^{1} \mathrm{H}-\mathrm{NMR}$ of $\mathrm{N}$-[2-(benzyloxy) benzoyl]-L-Serine methyl ester (20) in 107 $\mathrm{CDCl}_{3}$

Figure A1.30: $\quad{ }^{1} \mathrm{H}-\mathrm{NMR}$ of (S)-Methyl 2-[2-Benzyloxy) phenyl]-1,3-oxazoline-4carboxylate (21) in $\mathrm{CDCl}_{3}$ 


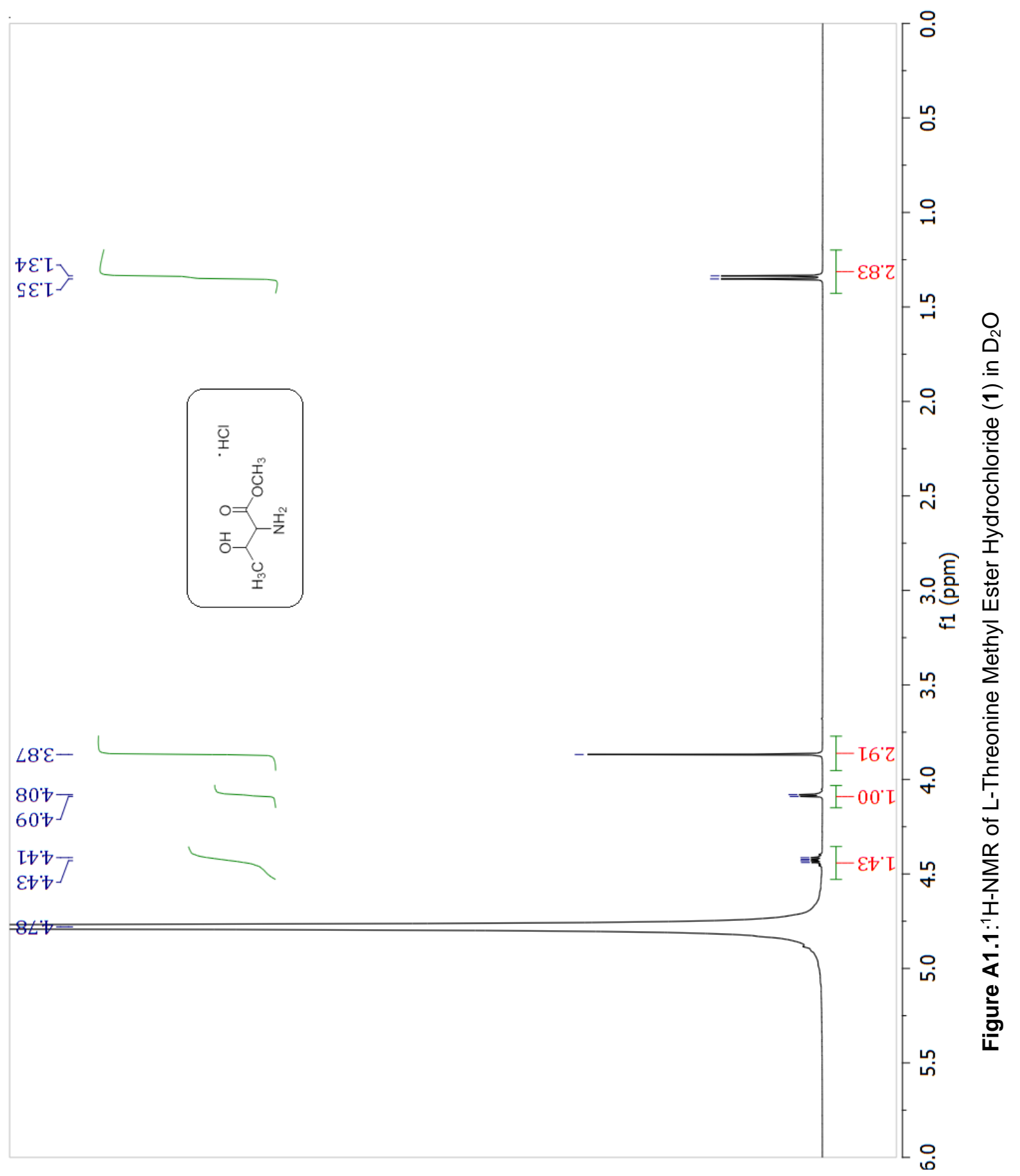




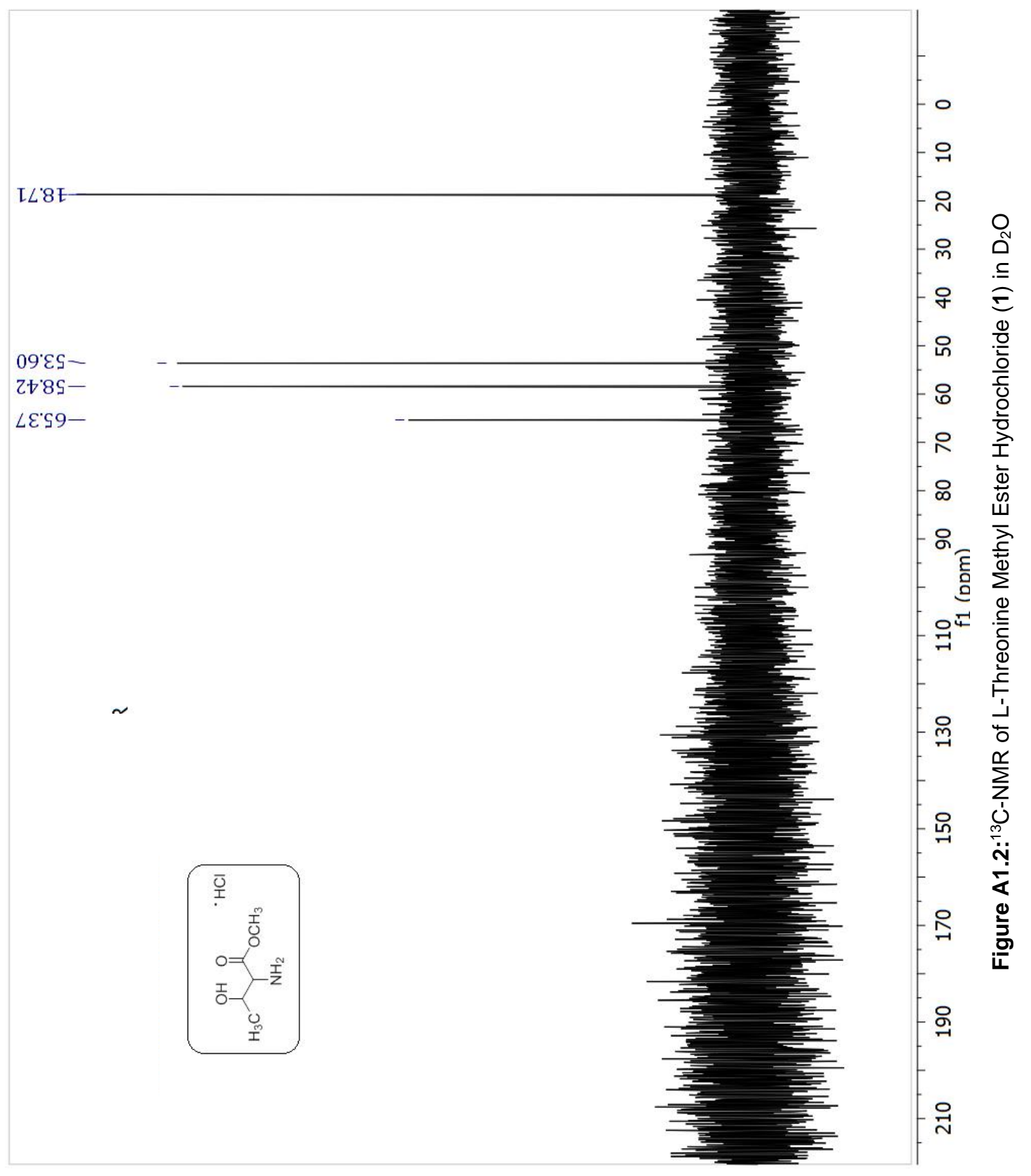




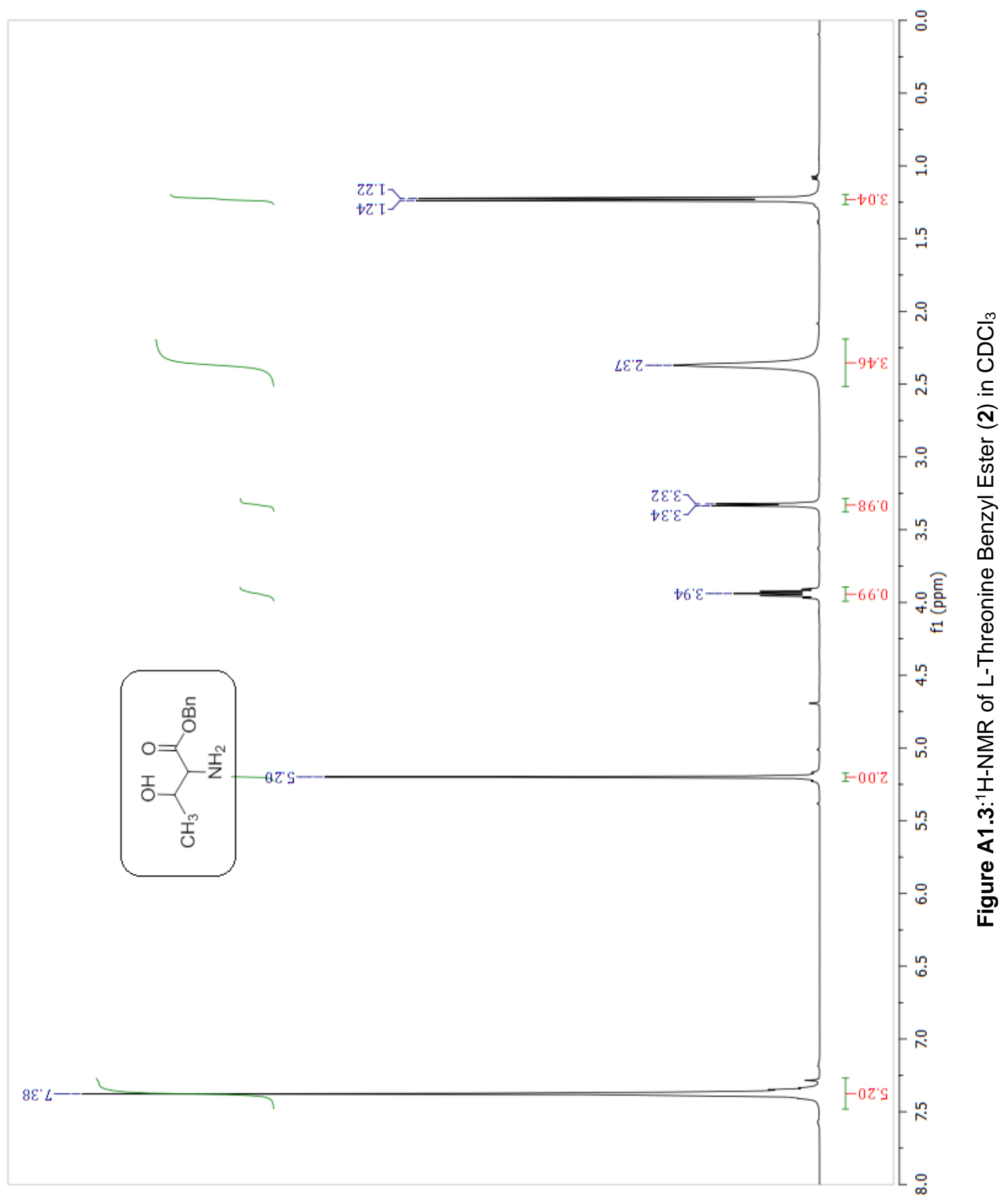




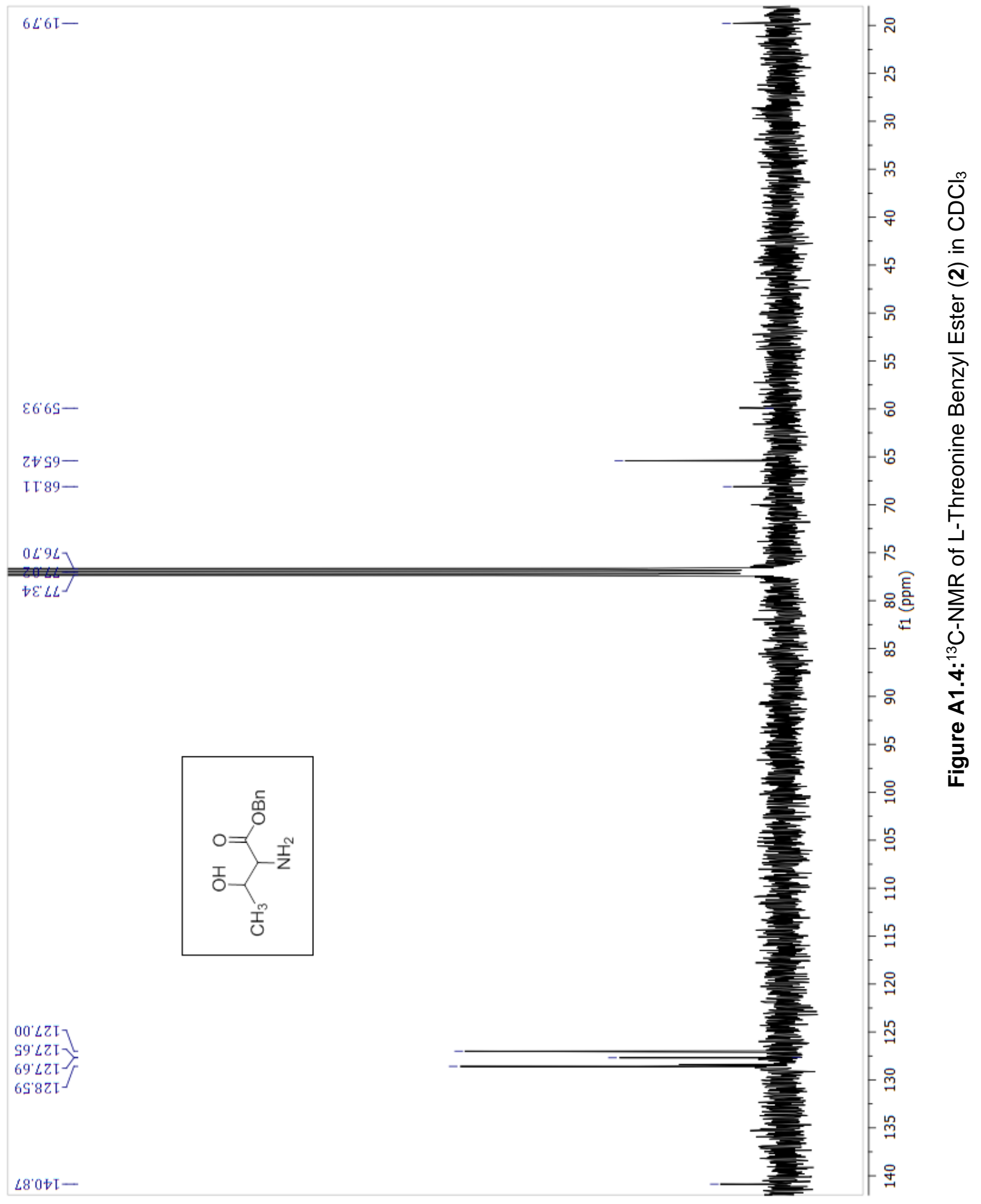




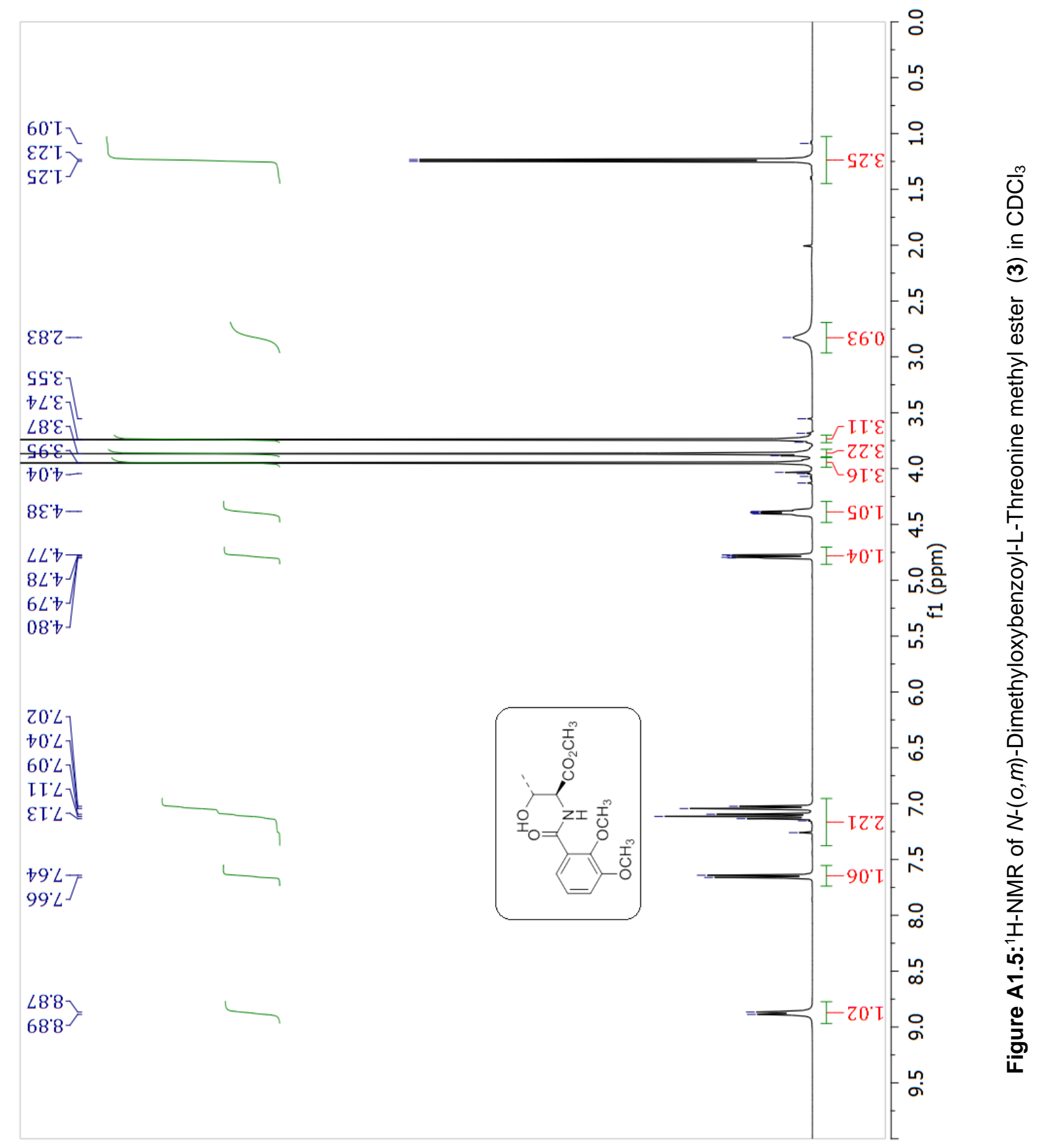




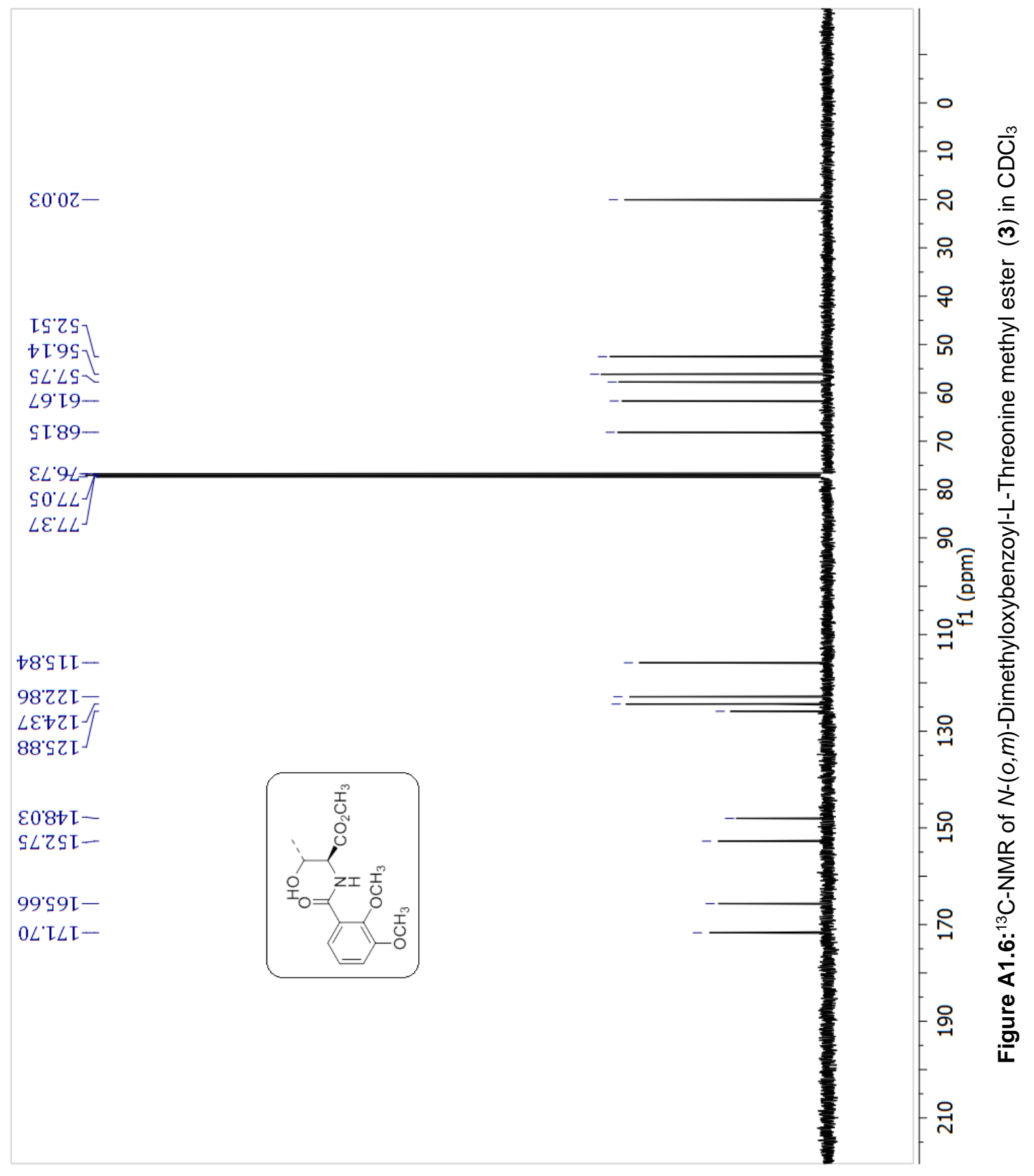




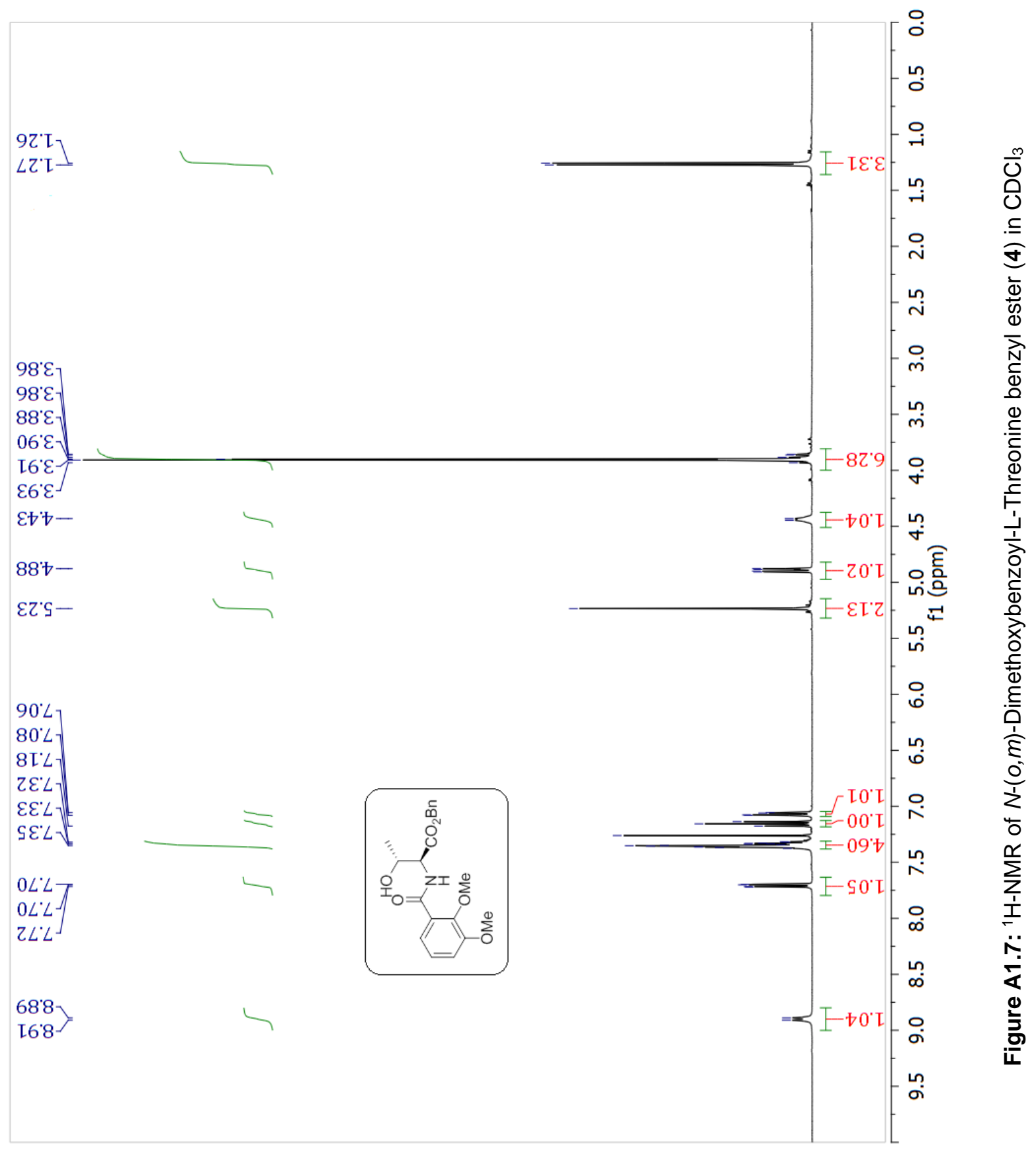




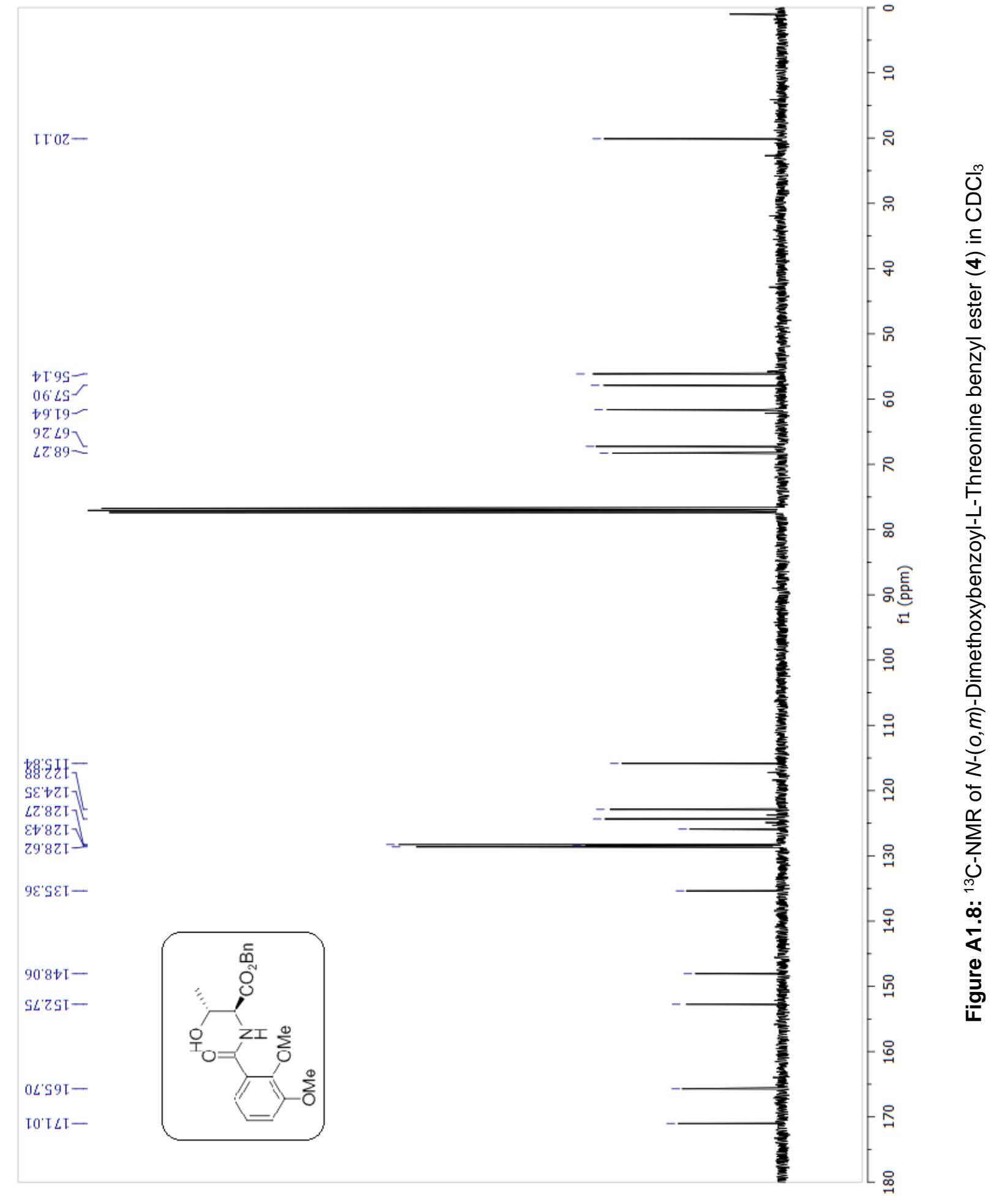




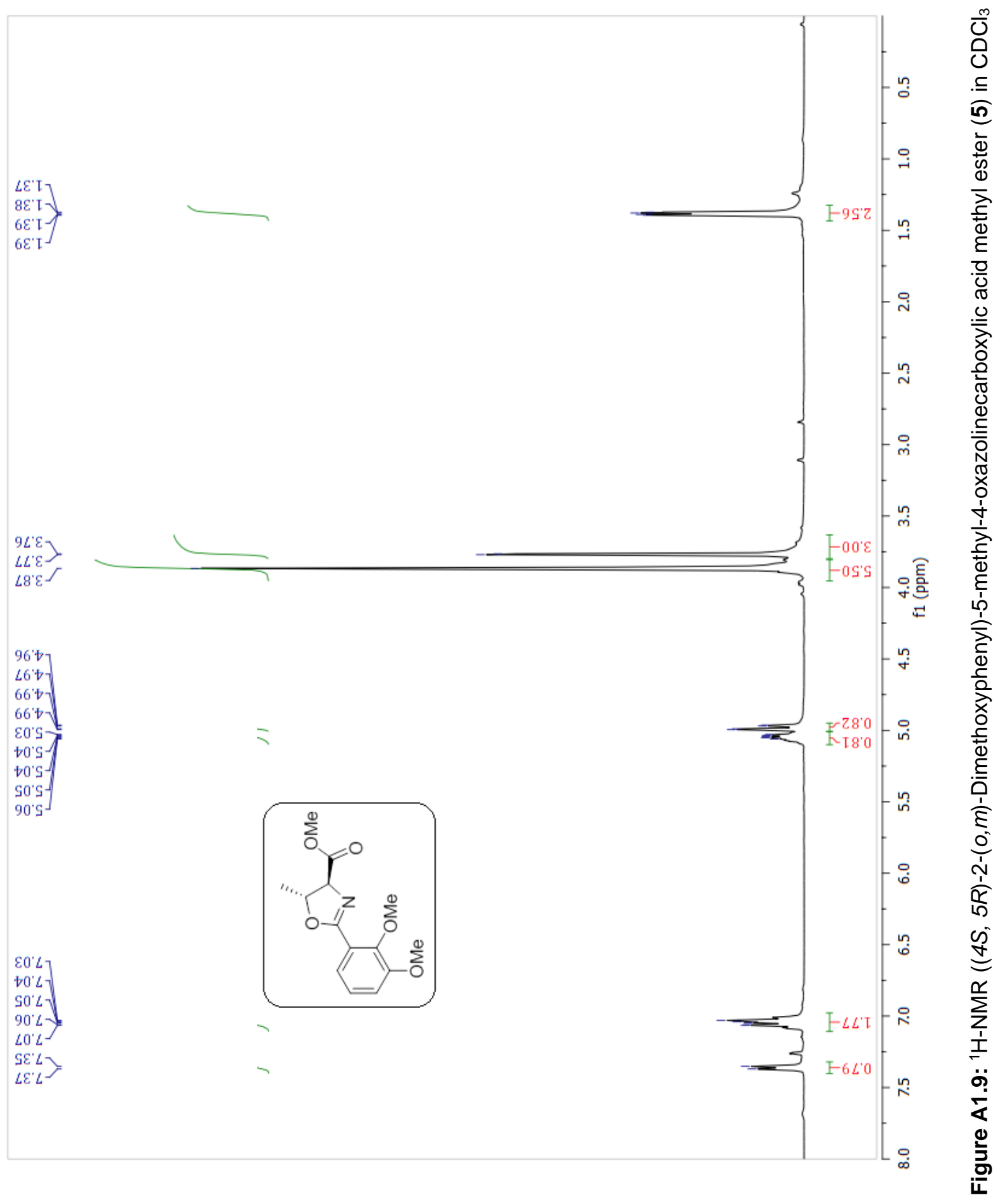




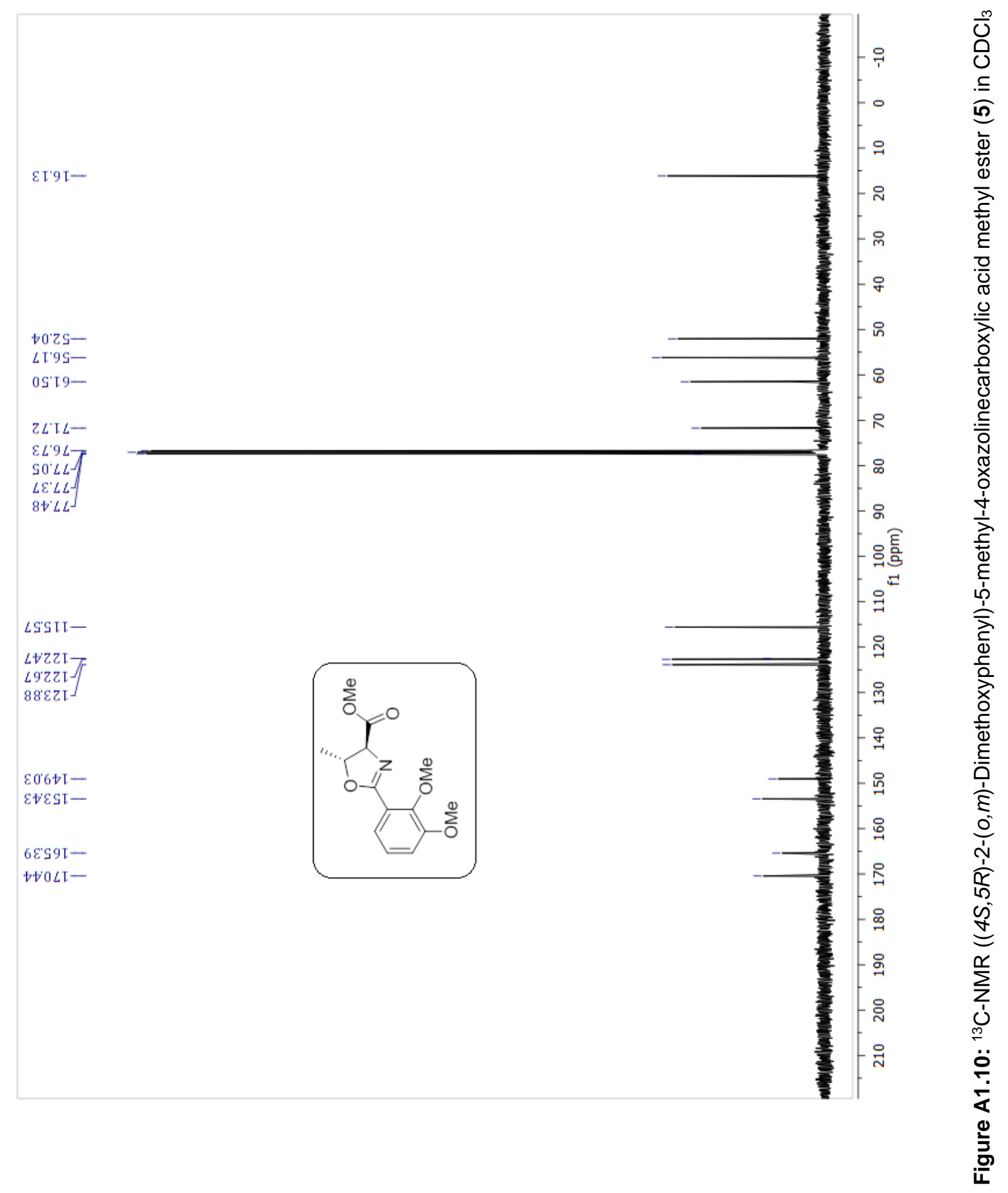




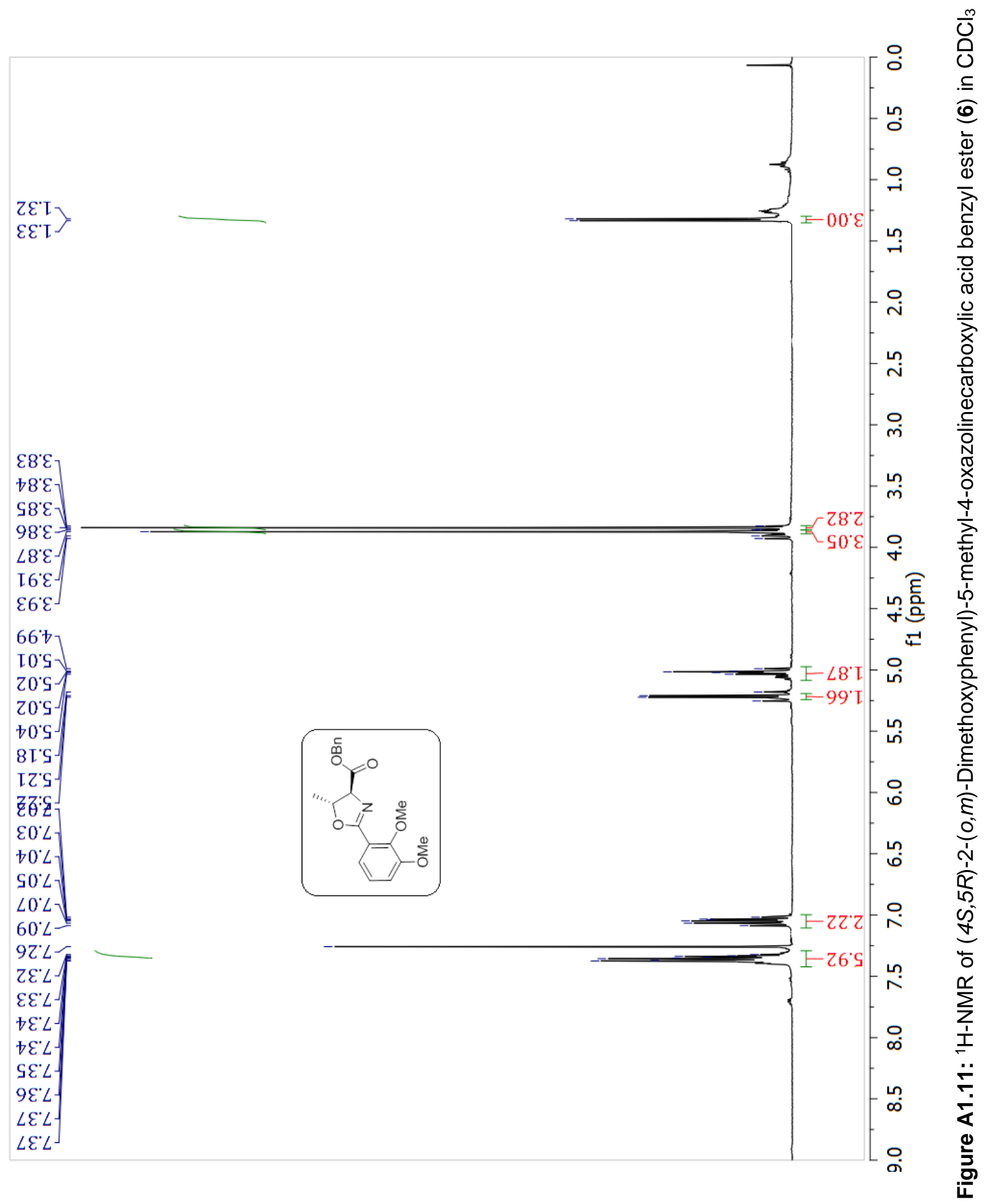




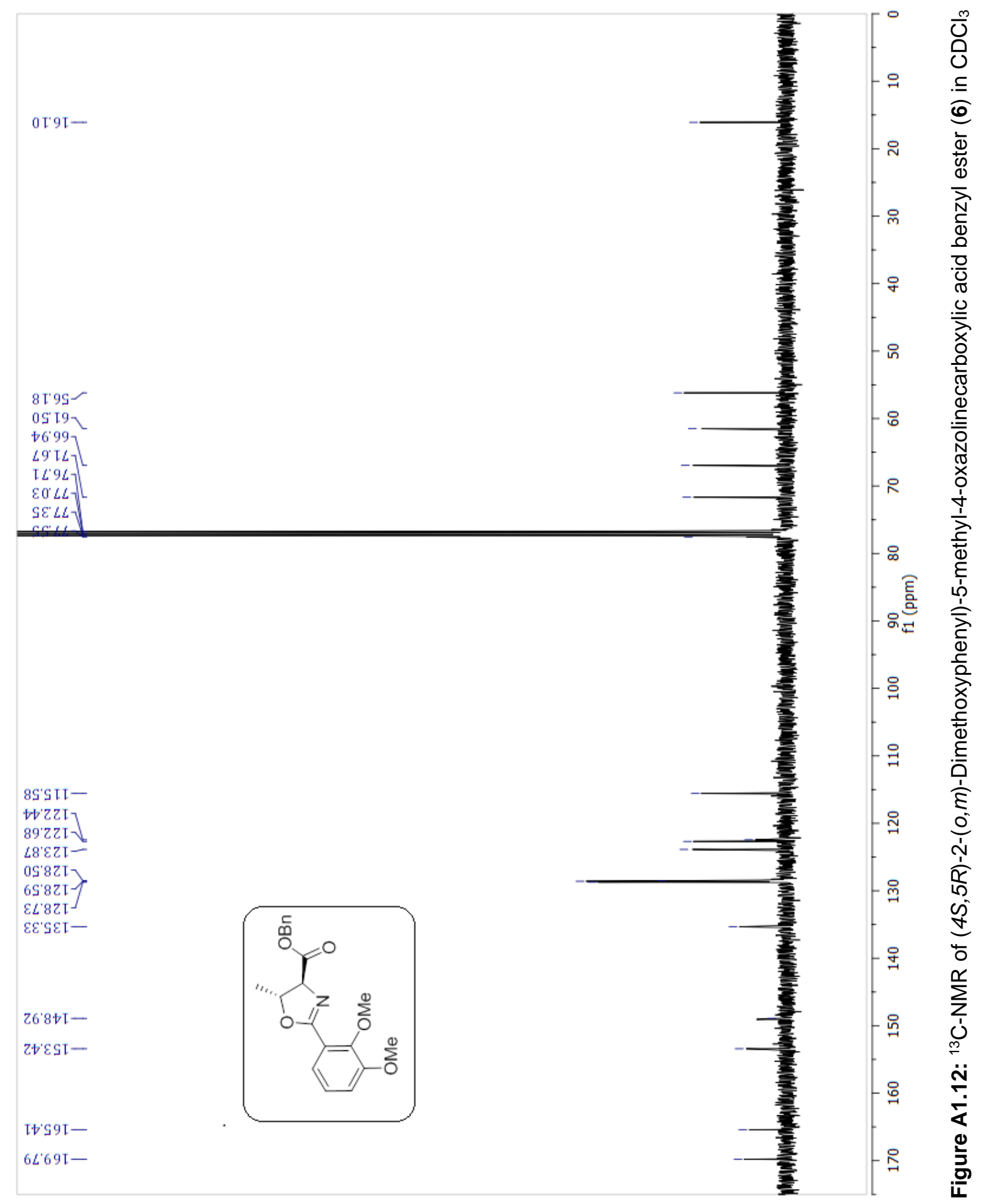




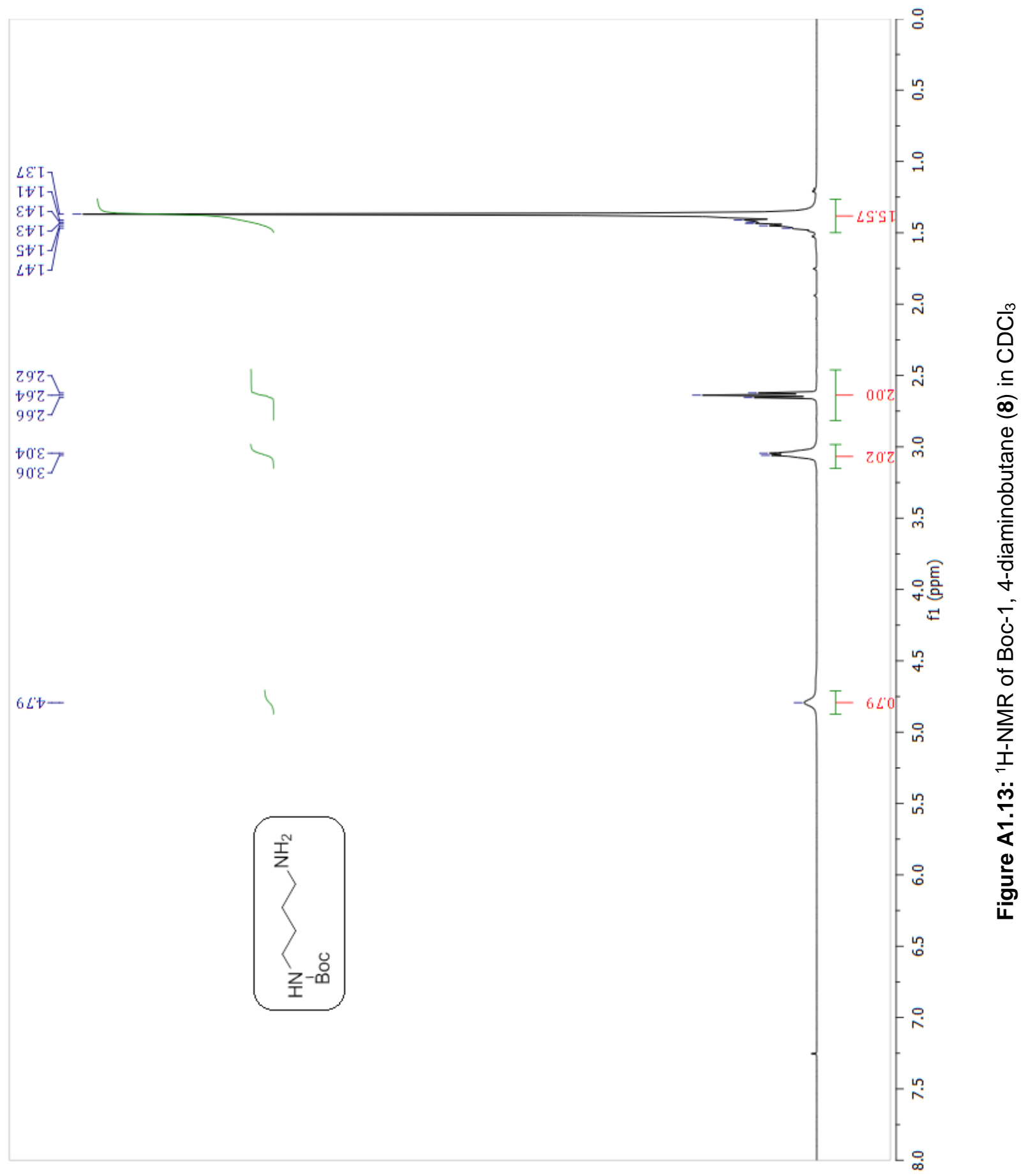




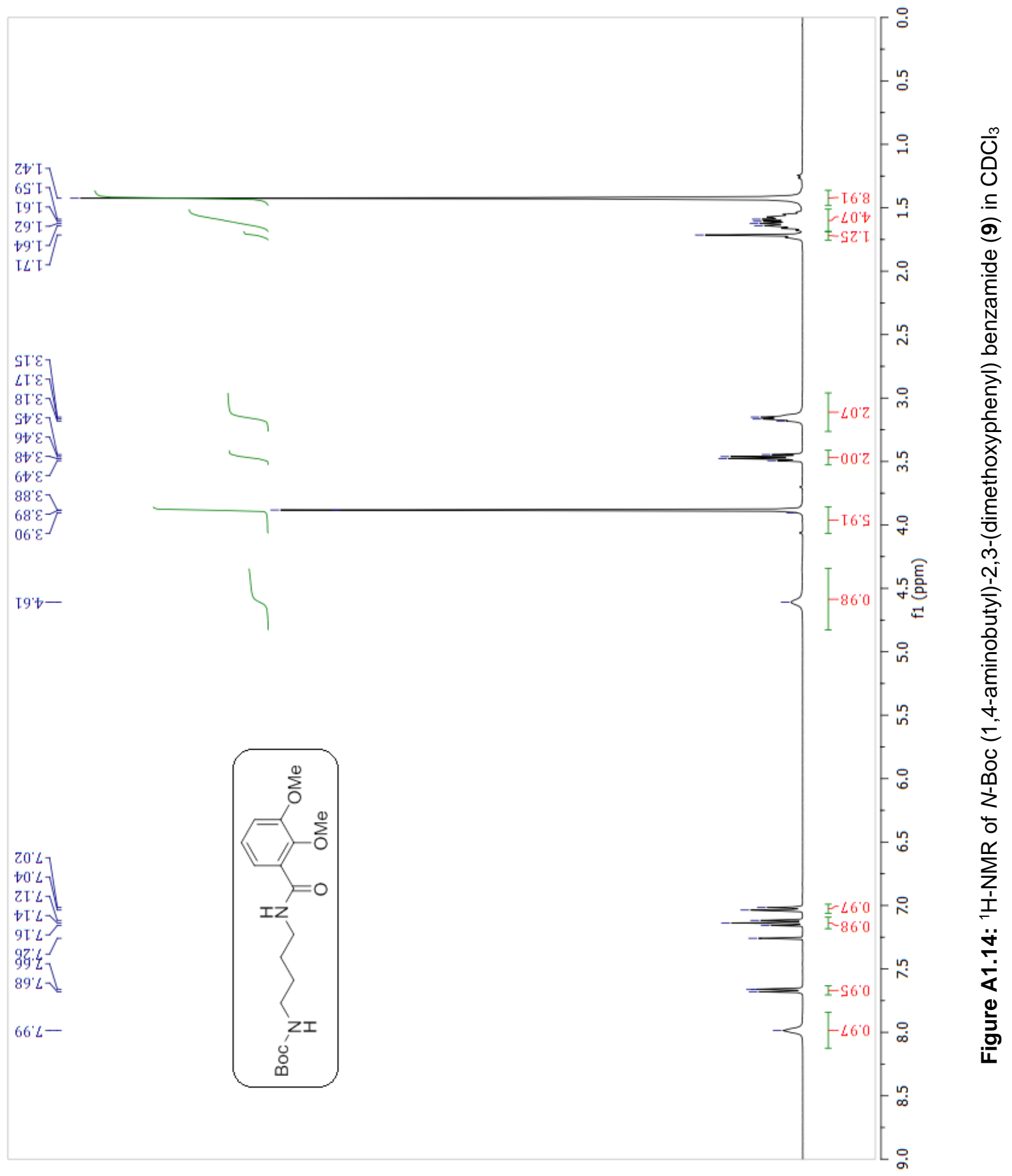




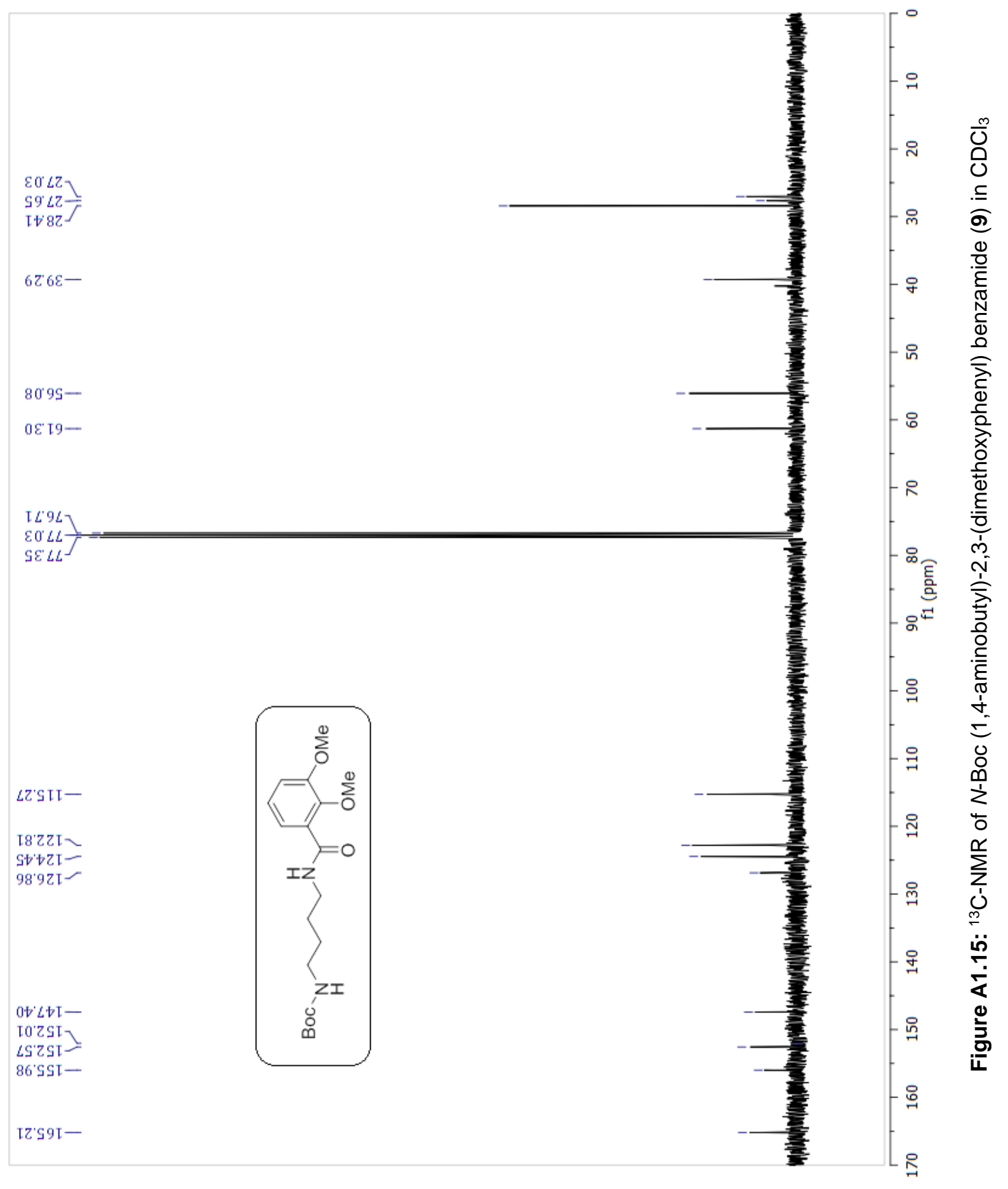




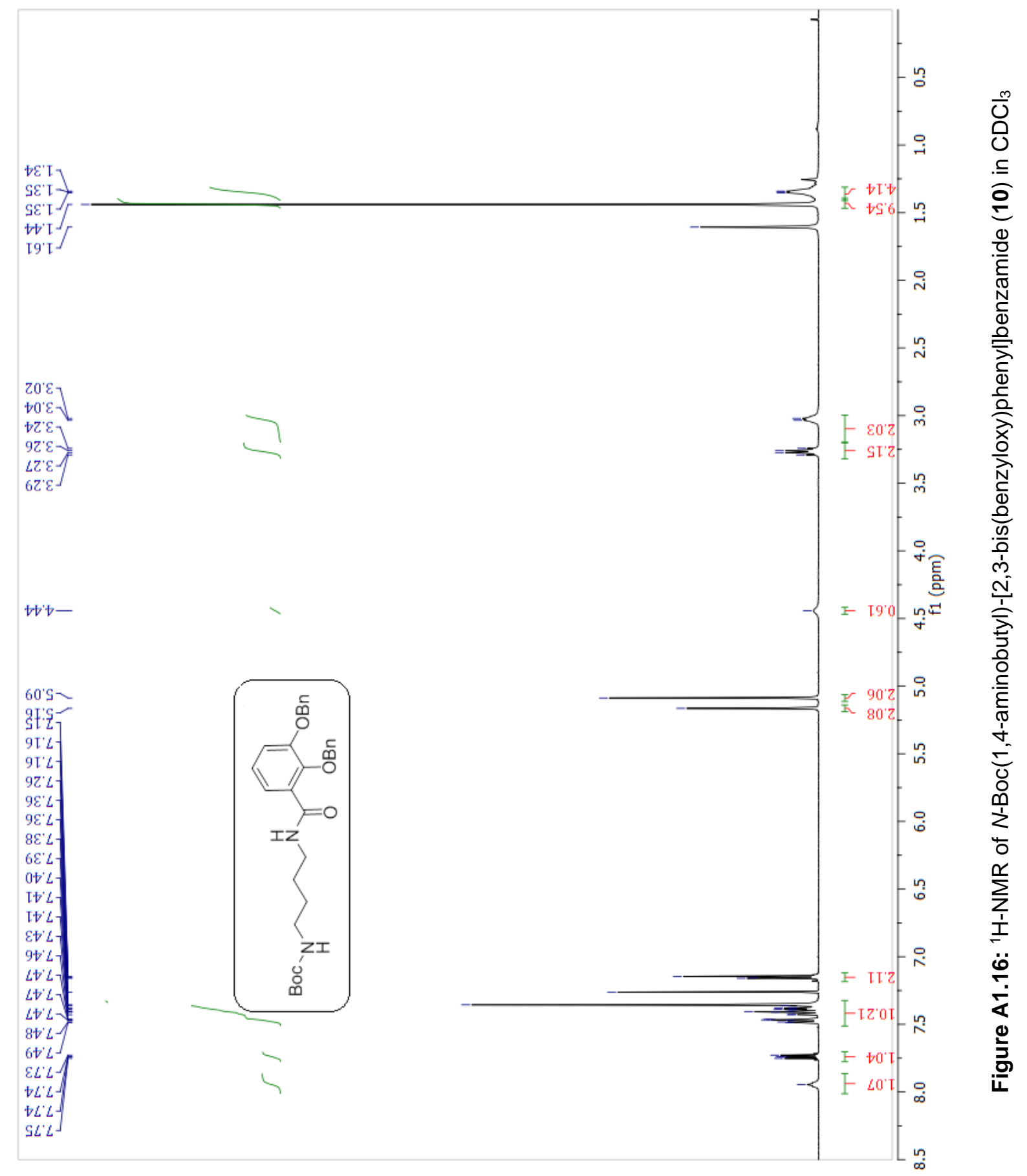




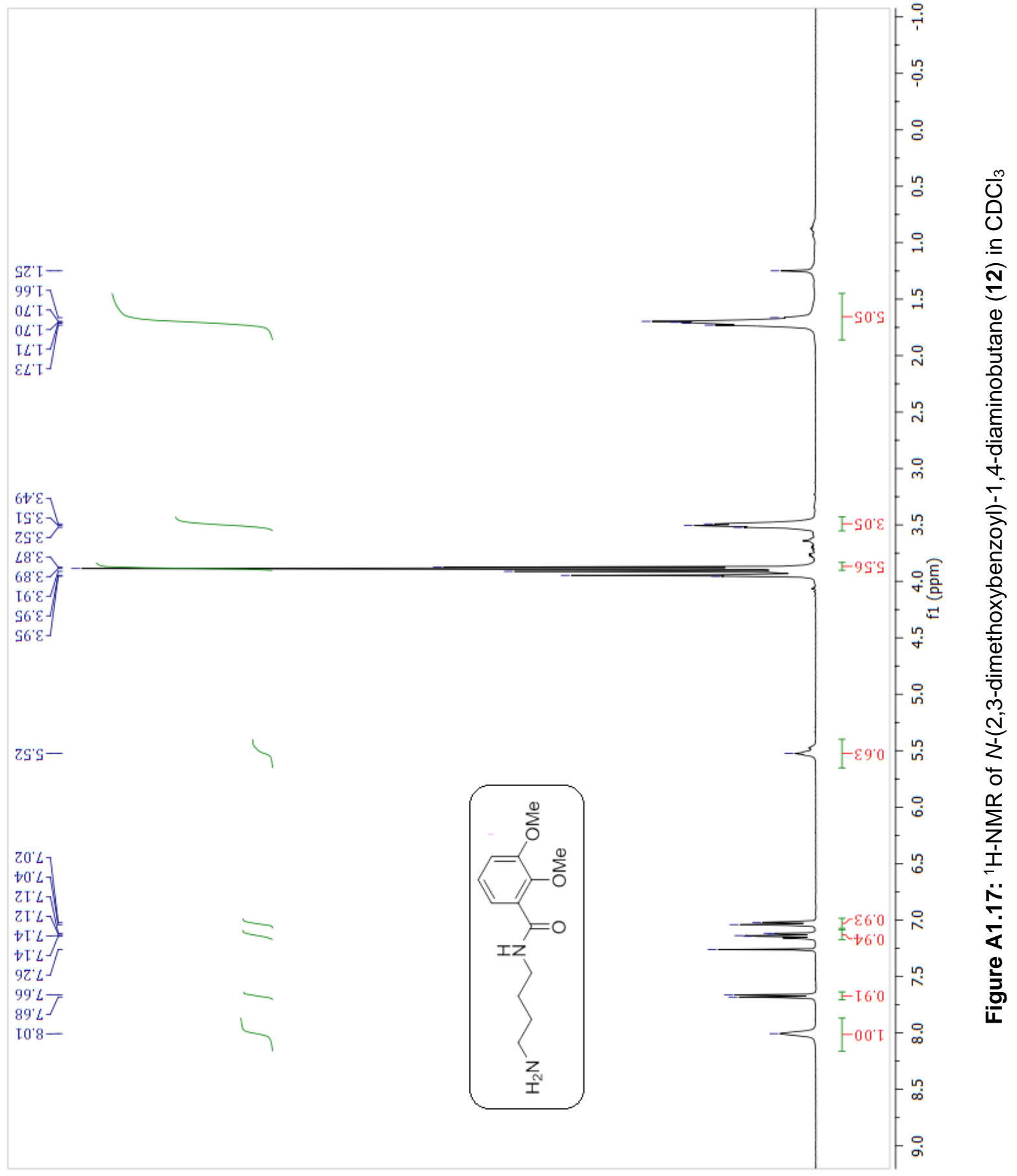




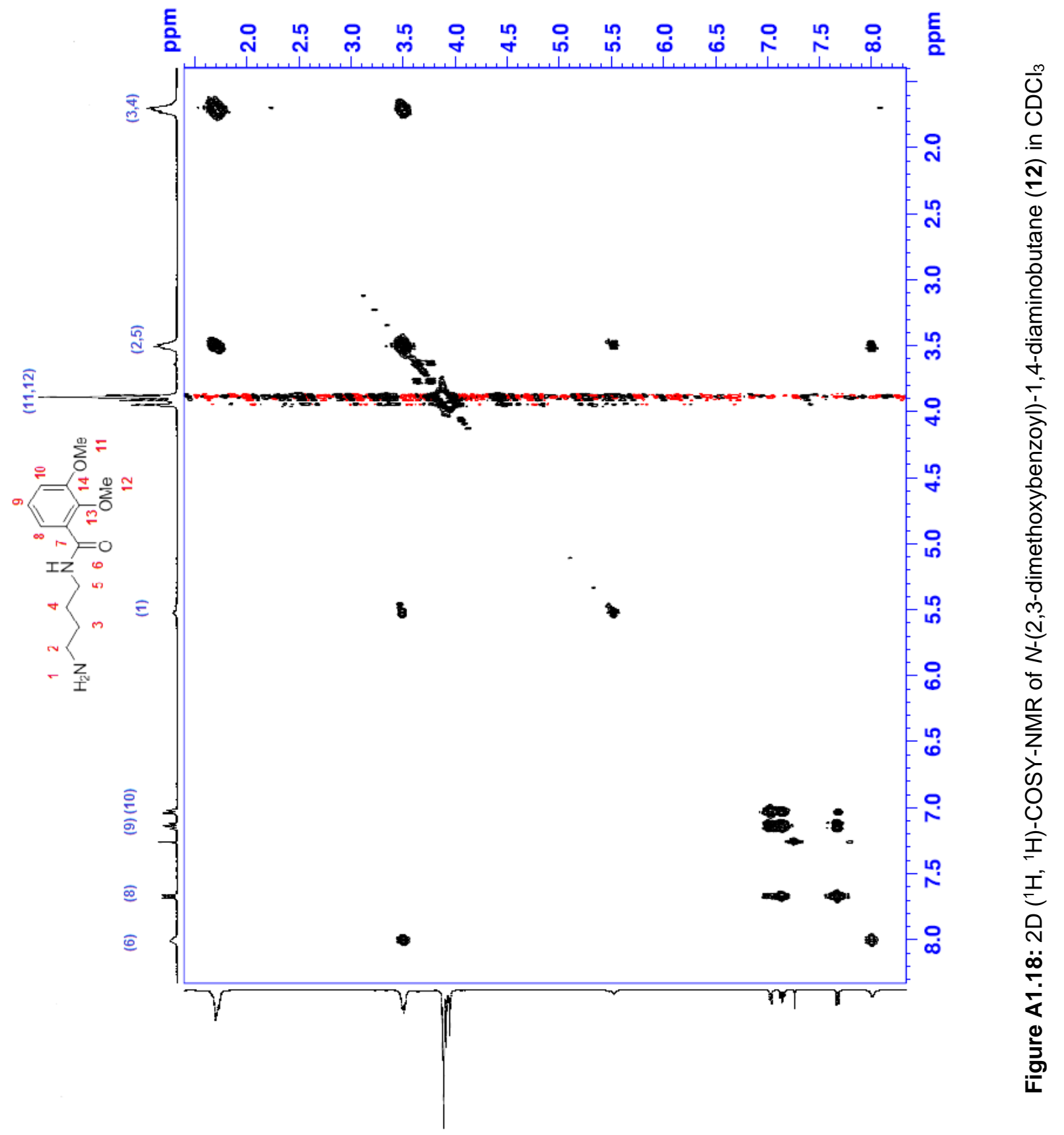




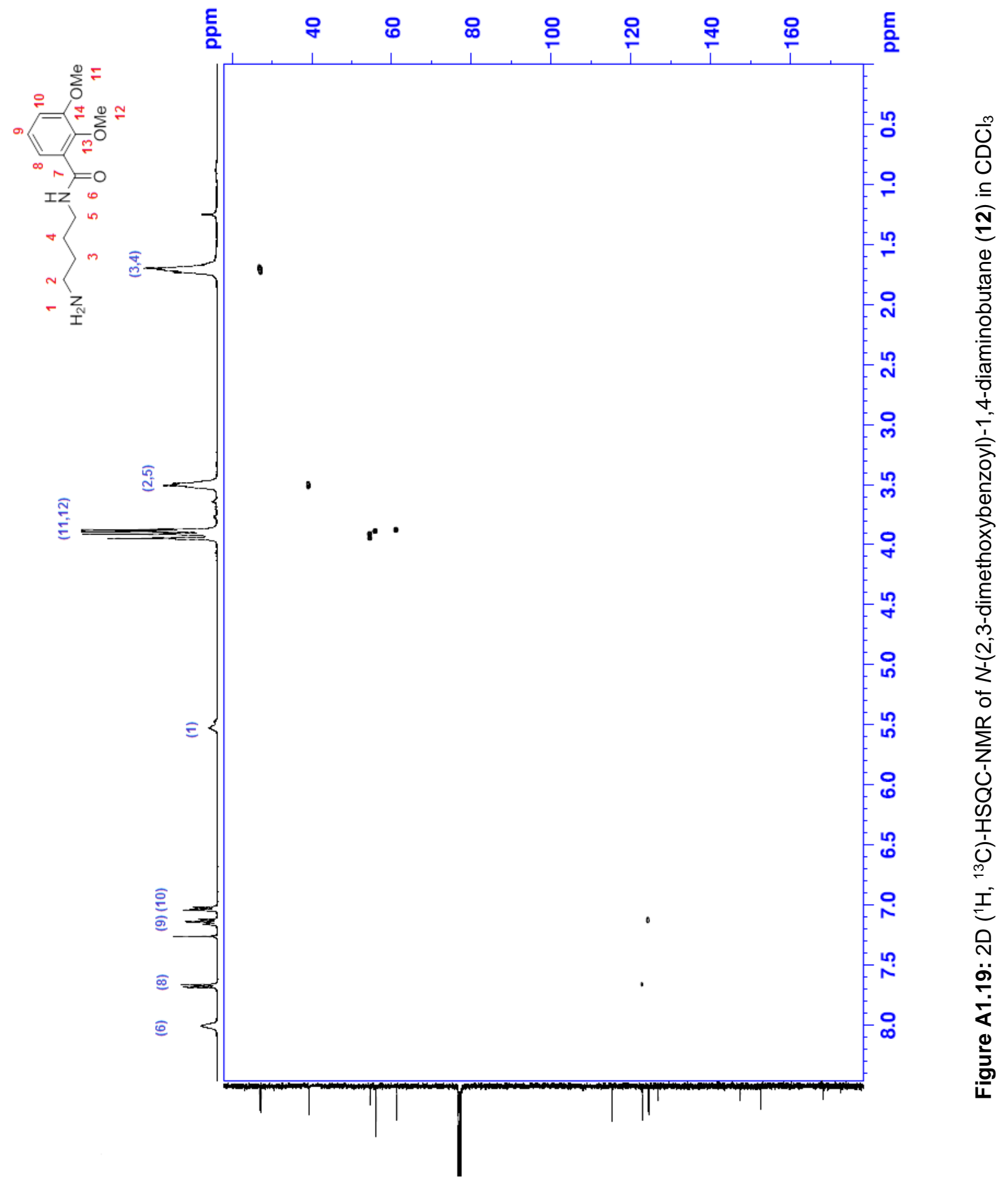




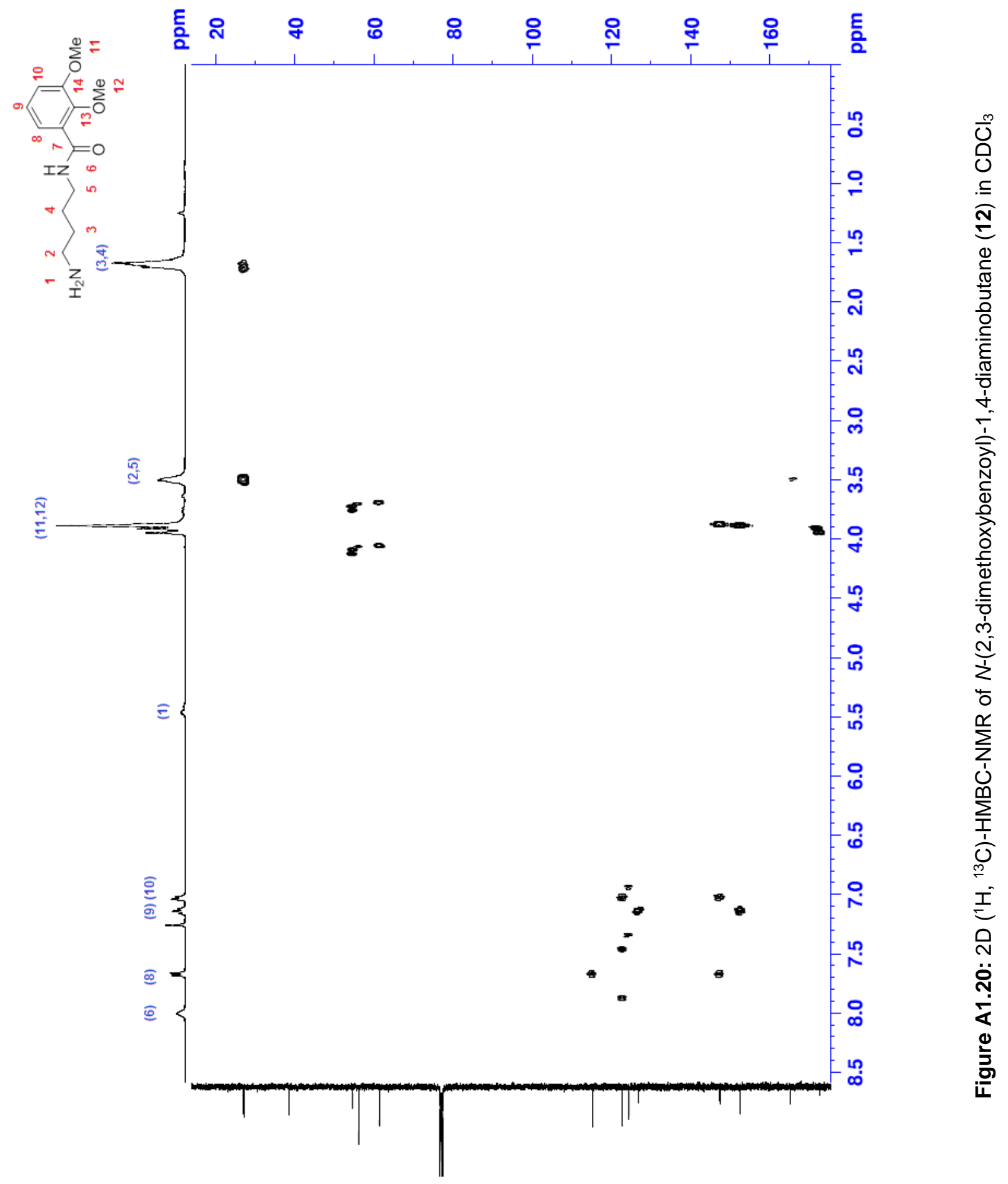




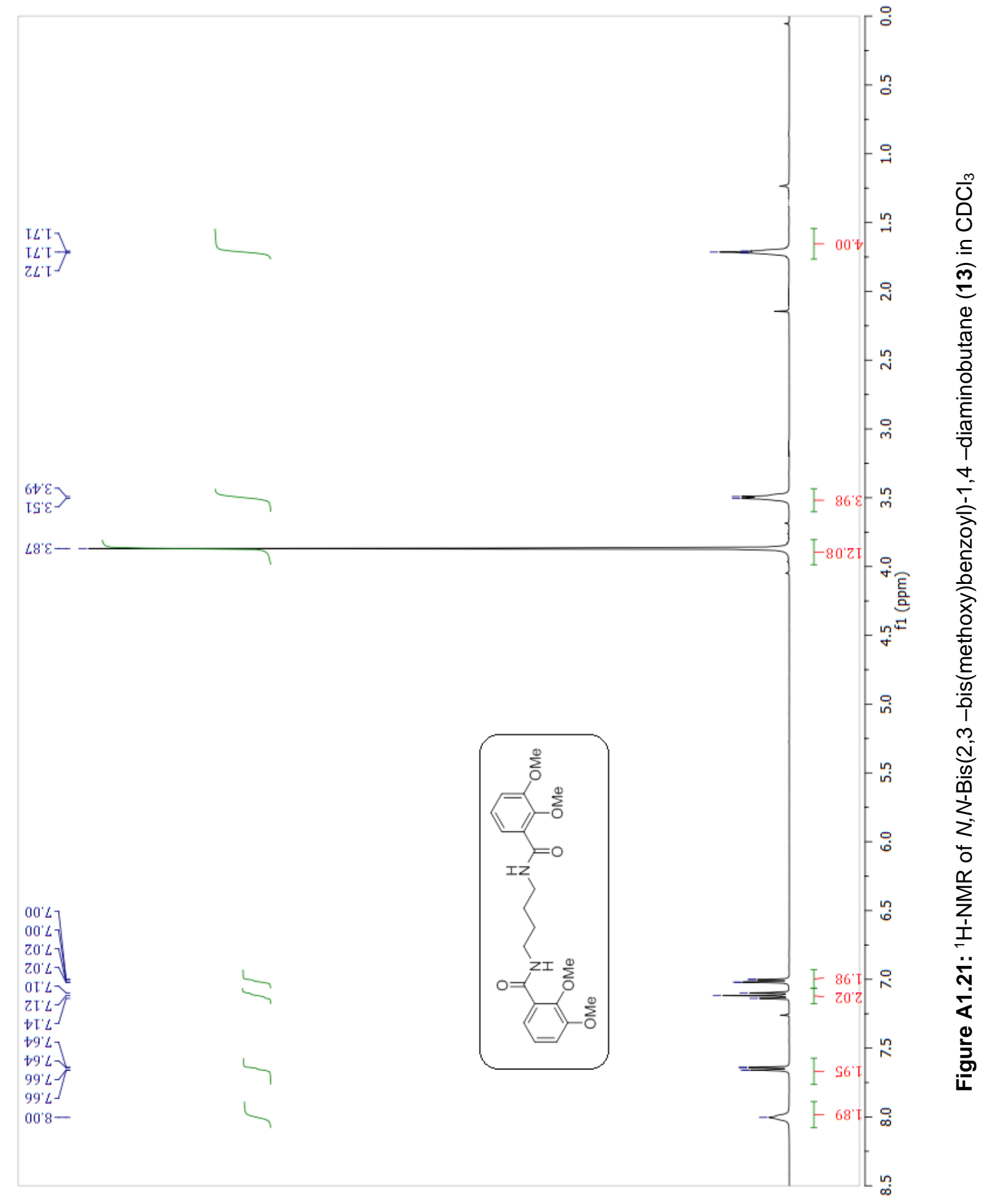




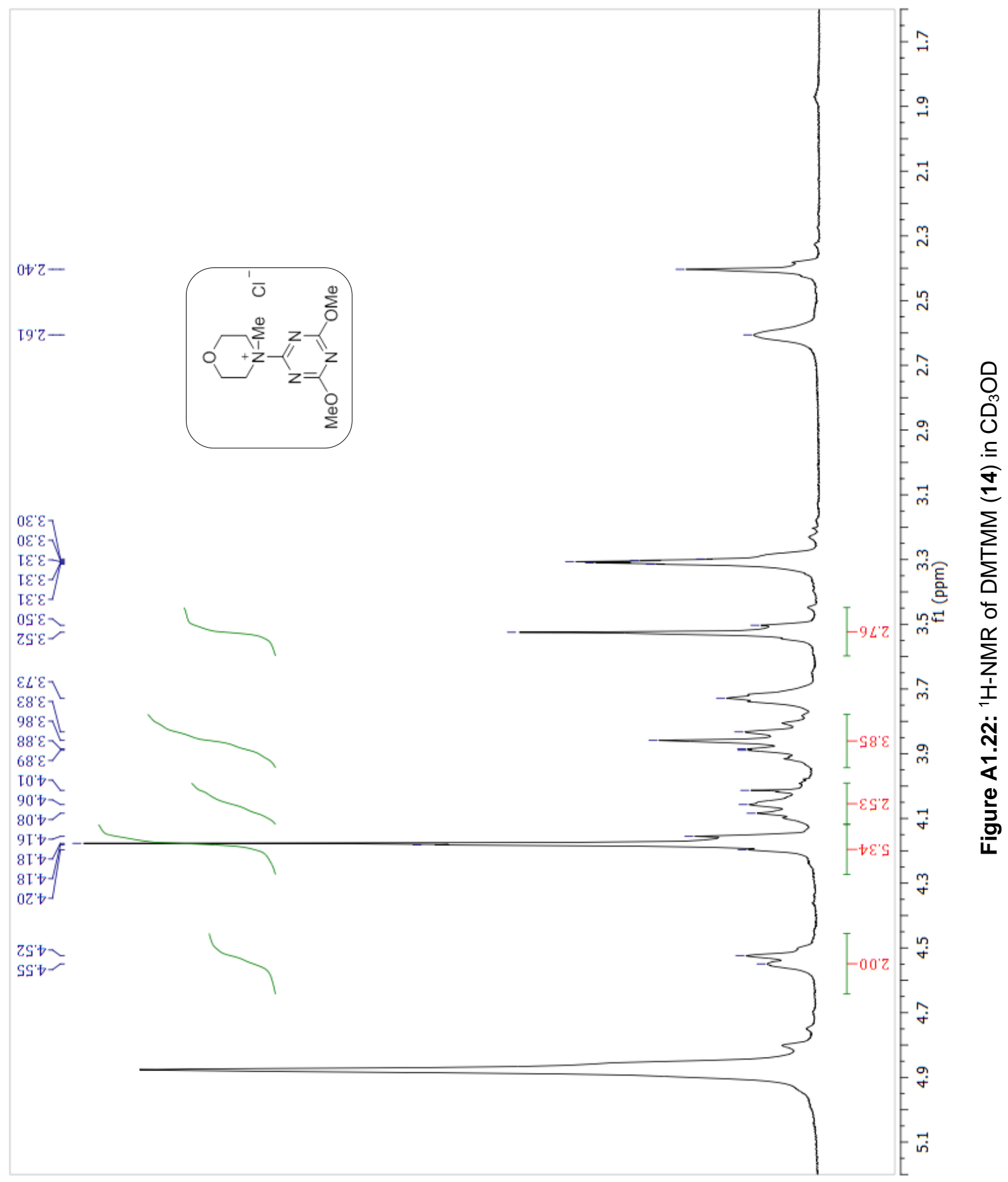




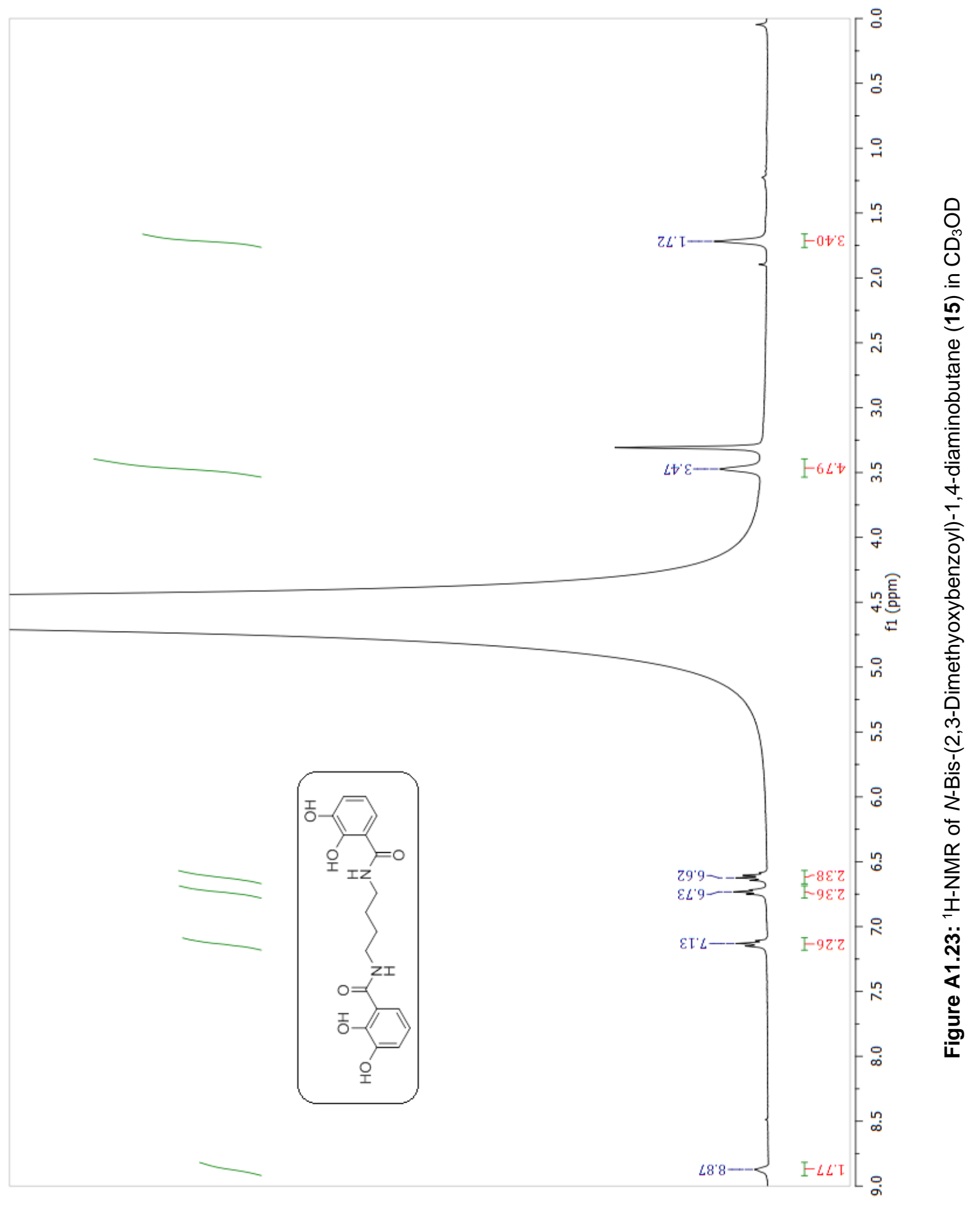




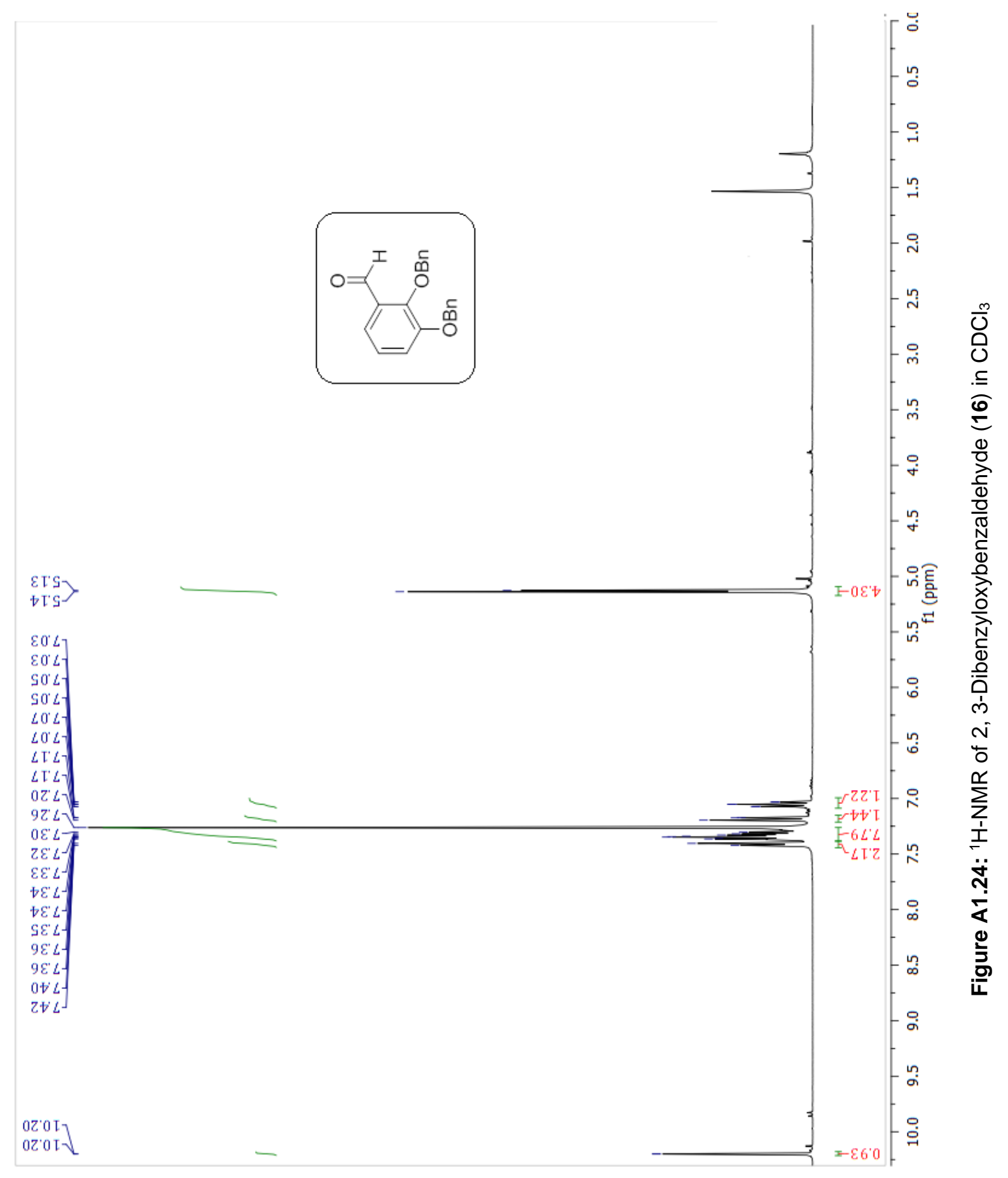




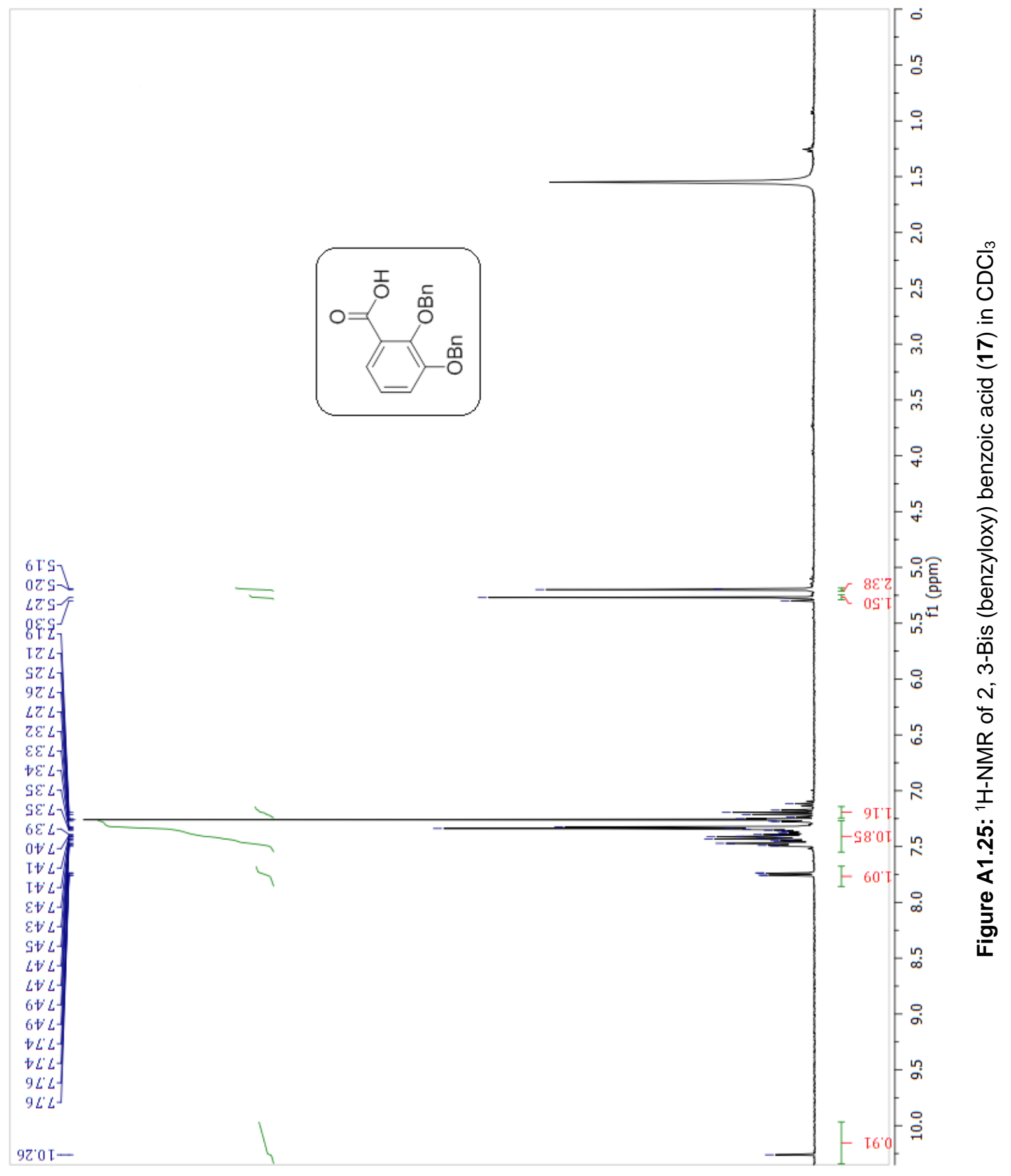




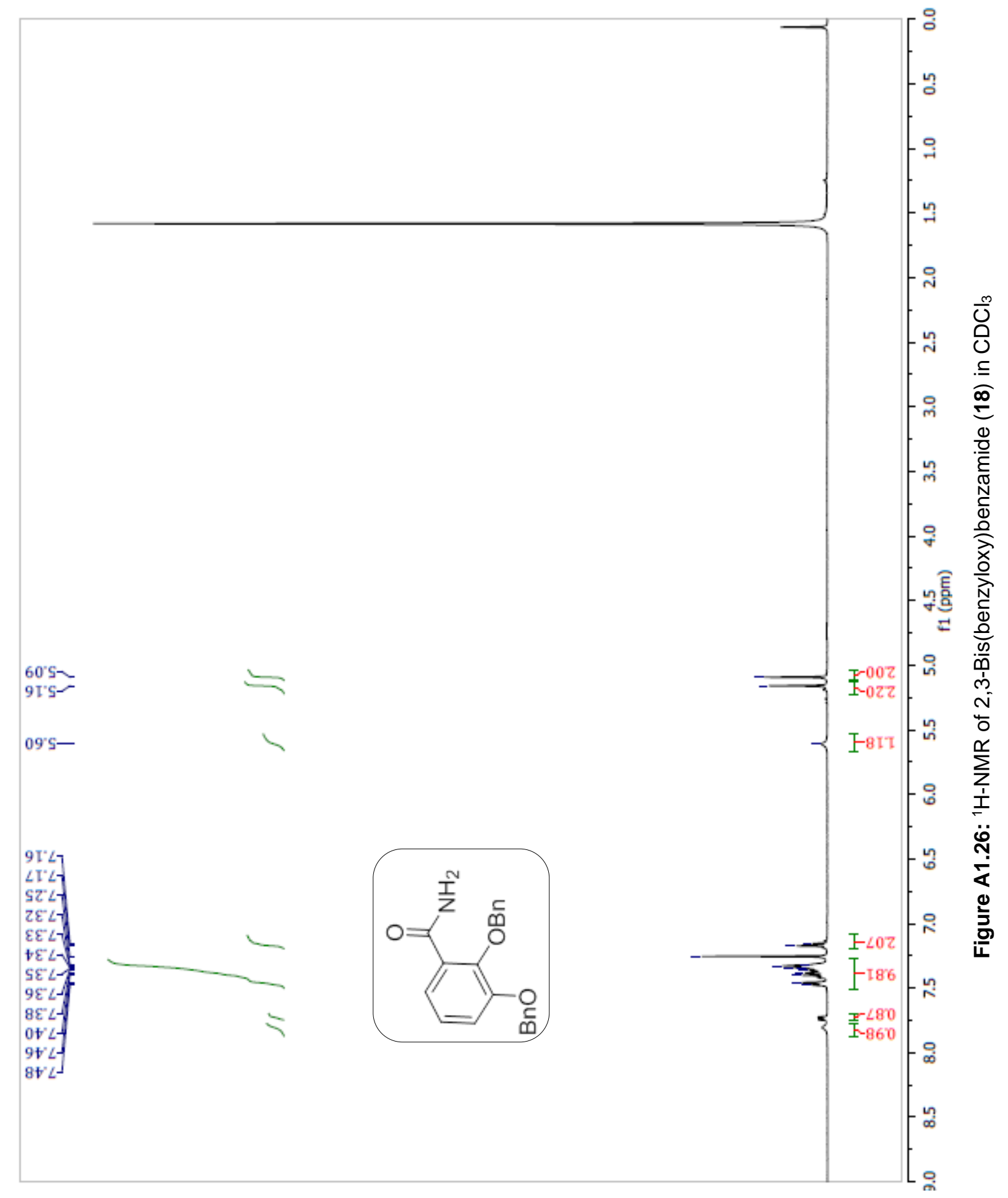




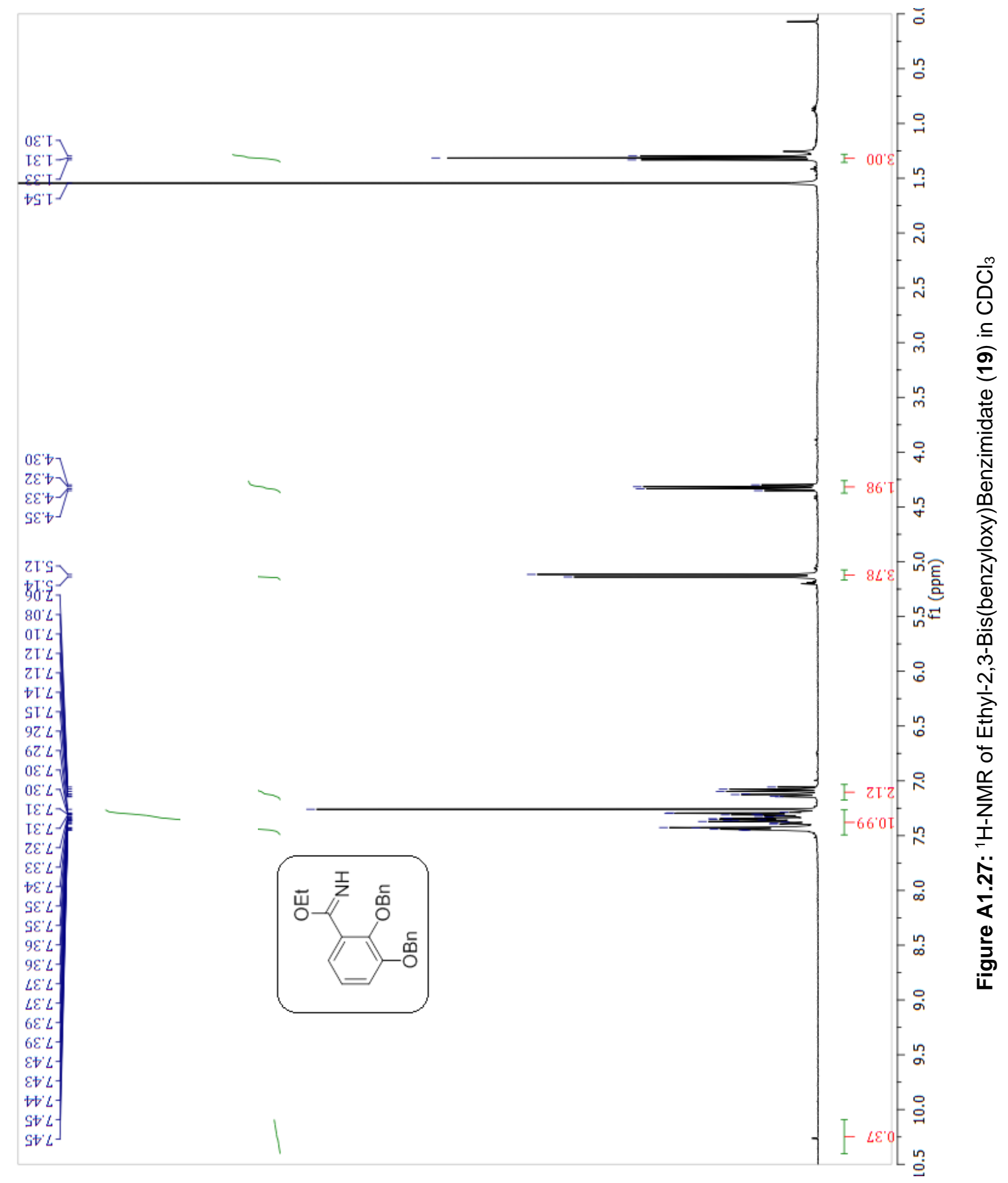




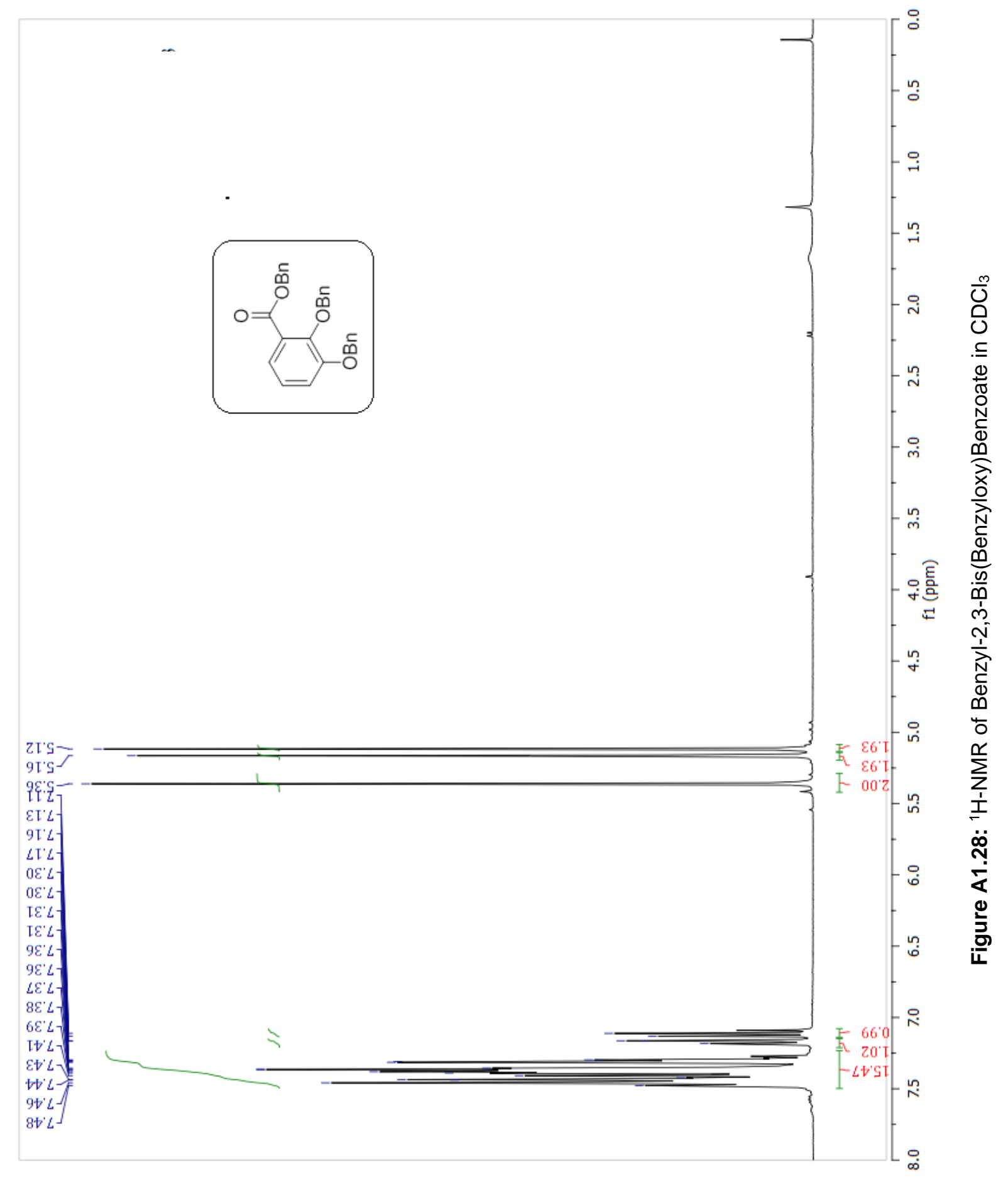




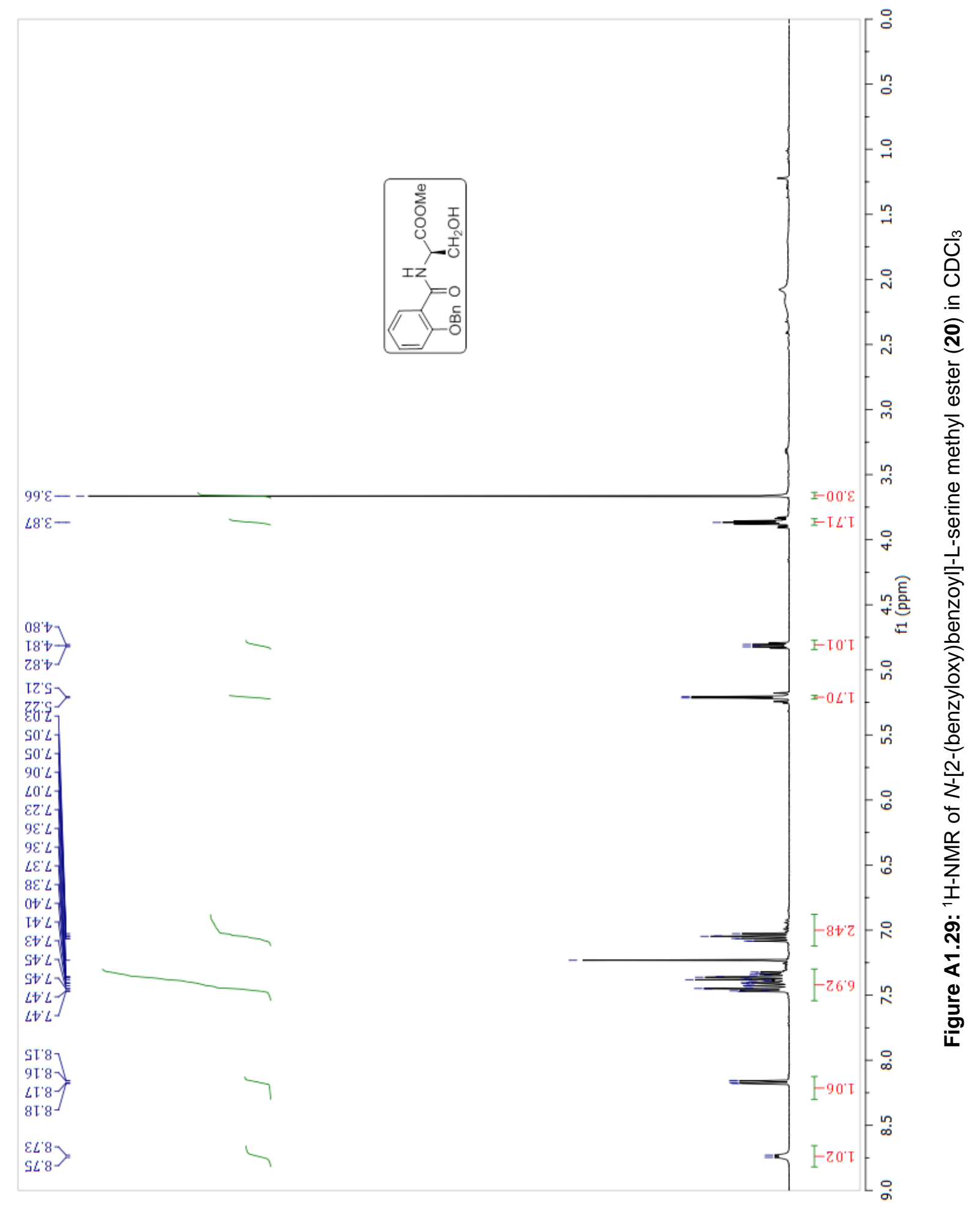




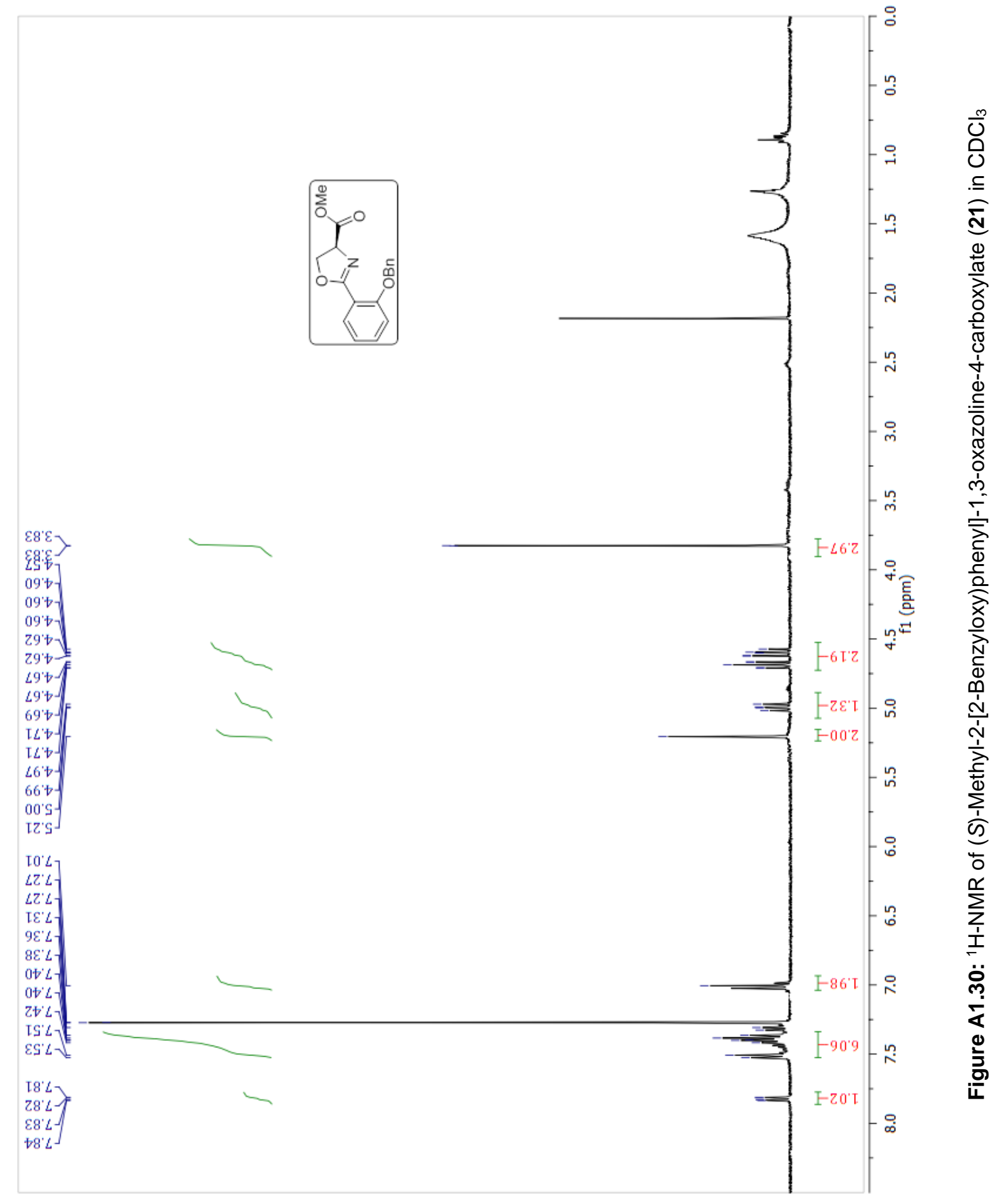


Figure A2.1: Absorption spectra of compound (15) in $\mathrm{MeOH}$ with and without $\mathrm{Fe}^{3+}$

Figure A2.2: UV Spectrum of Photobactin using Spartan'10. 


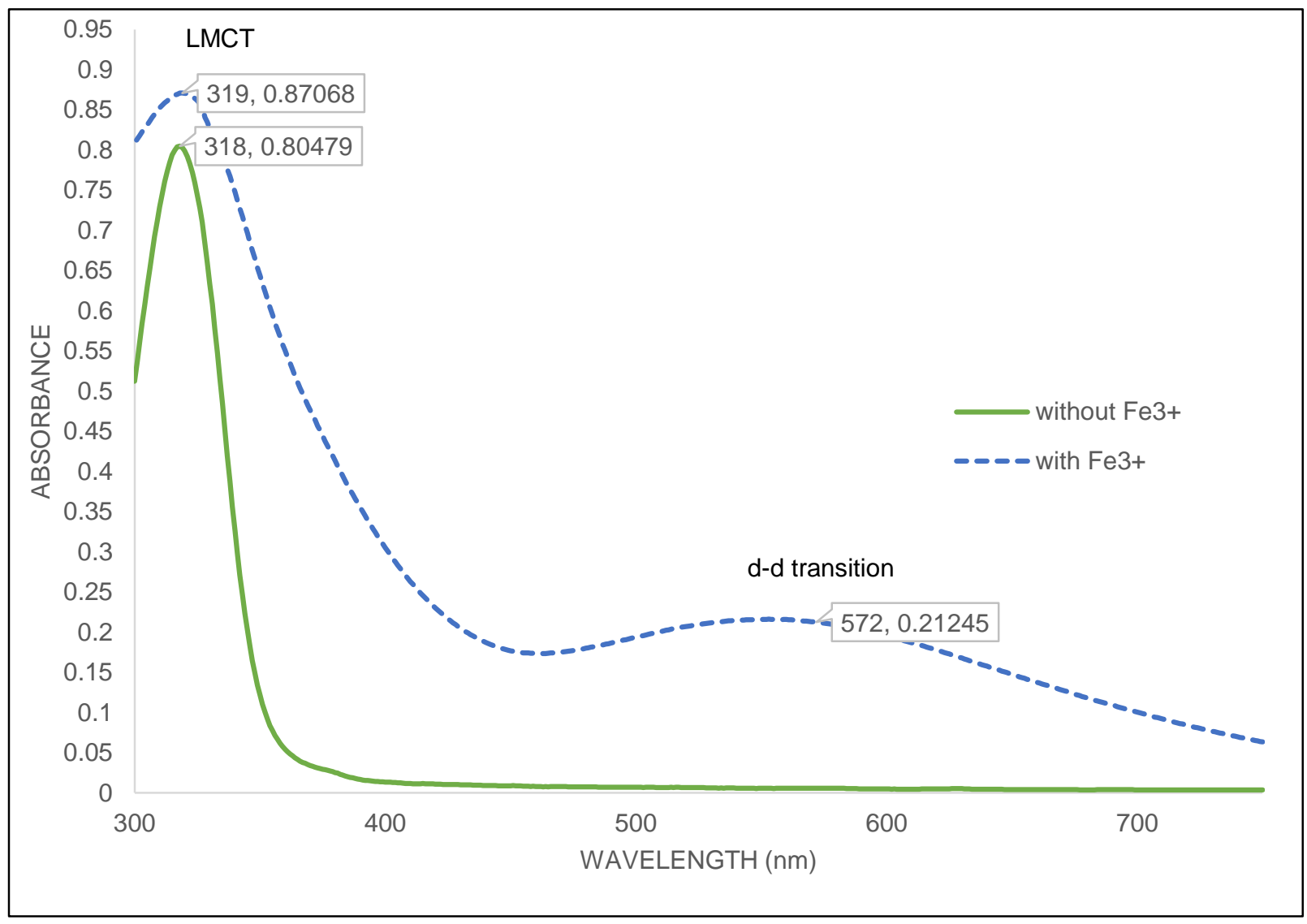

Figure A2.1: Absorption spectra of compound (15) in $\mathrm{MeOH}$ with and without $\mathrm{Fe}^{3+}$ 


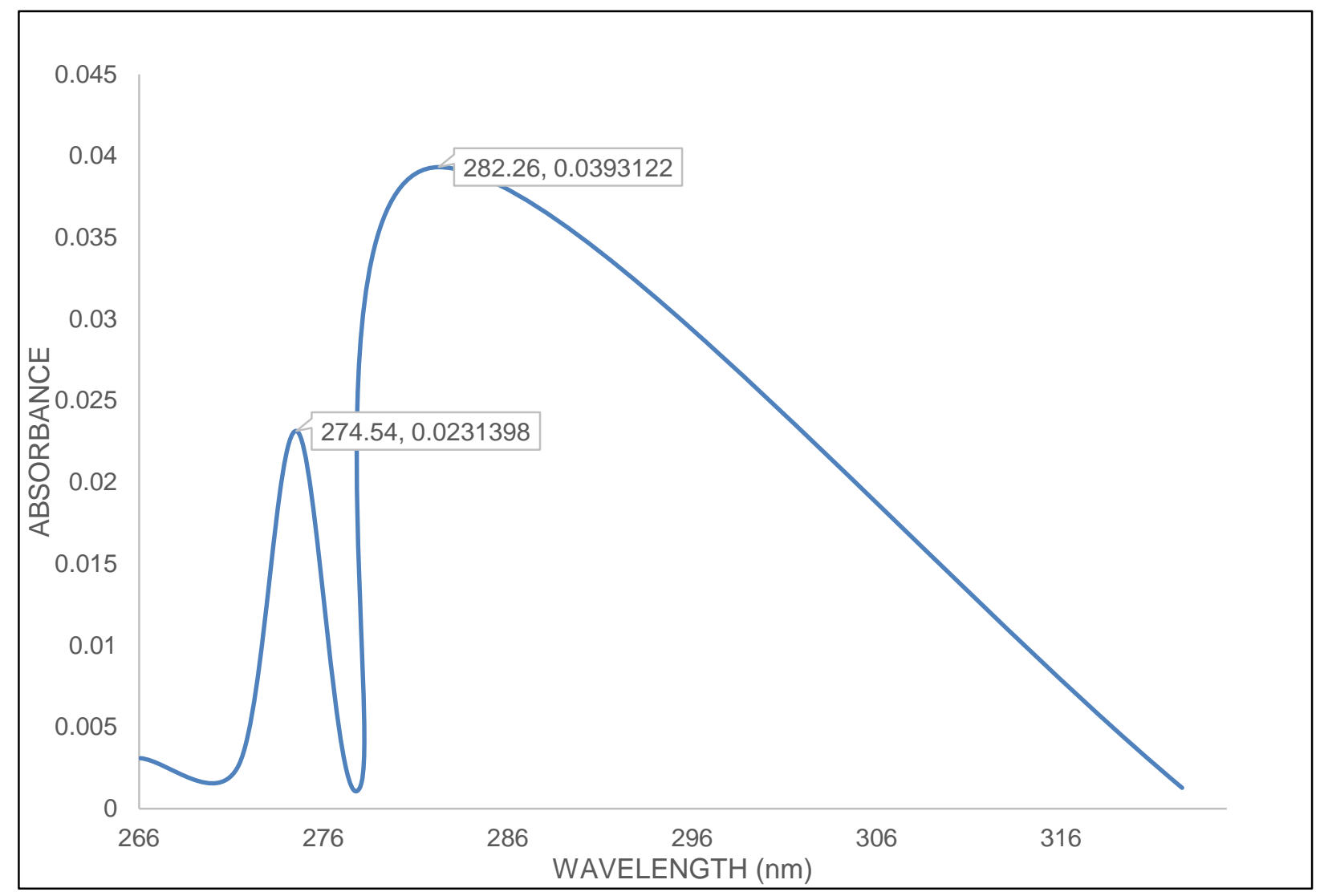

Figure A2.2: UV Spectrum of Photobactin using Spartan'10. 


\section{References}

1. Witte, H., Seeliger, W. Simple Synthesis of 2-Substituted 2-Oxazolines and 5, 6-Dihydro-4H-1, 3oxazines. Angew. Chem. Int. Ed. Engl., 1972, 11, 287.

2. Robinson, R. A new synthesis of oxazole derivatives. J. Chem. Soc., 1909, 95, 2167.

3. Wiley, R. H. The Chemistry of the Oxazoles. Chem. Rev., 1945, 37, 401.

4. Dewar, M. J. S., Turchi, I. J. Cornforth rearrangement. J. Am. Chem. Soc., 1974, 96, 6148.

5. Saha, R., Saha, N., Donofrio, R. S. Bestervelt, L. L. Microbial siderophores: a mini review. J. Basic Microbiol., 2013, 53, 303.

6. Miethke, M., Marahiel, M.A. Siderophore-based iron acquisition and pathogen control. Microbiol. Mol. Biol. Rev., 2007, 71, 413.

7. Griffiths, G. L., Sigel, S. P., Payne, S. M., Neilands, J. B. Vibriobactin, a siderophore from Vibrio cholerae. J. Biol. Chem., 1984, 259, 383.

8. Hider, R. C., Kong, X. Chemistry and biology of siderophores. Nat. Prod. Rep., 2010, 27, 637.

9. Seyedsayamdost, M. R., Cleto, S., Carr, G., Vlamakis, H., Vieira, M.J., Kolter, R., Clardy, J. Mixing and Matching Siderophore Clusters: Structure and Biosynthesis of Serratiochelins from Serratia sp. V4. J. Am. Chem. Soc., 2012, 134, 13550.

10. Li, N., Zhang, C., Li, B., Liu, X., Huang, Y., Xu, S., Gu, L. Unique iron coordination in iron-chelating molecule vibriobactin helps Vibrio cholerae evade mammalian siderocalin-mediated immune response. J. Biol. Chem., 2012, 287, 8912.

11. Mukai, A., Fukai, T., Matsumoto, Y., Ishikawa, J., Hoshino, Y., Yazawa, K., Harada, K., Mikami, Y. Transvalencin Z, a New Antimicrobial Compound with Salicylic Acid Residue from Nocardia transvalensis IFM 10065. J. Antibiot., 2006, 59, 366.

12. Ciche, T. A., Blackburn, M., Ensign, J.C. Photobactin: a Catechol Siderophore Produced by Photorhabdus luminescens, an Entomopathogen Mutually Associated with Heterorhabditis bacteriophora NC1 Nematodes. Appl. Environ. Microbiol., 2003, 69, 4706. 
13. Ong, S.A., Peterson, T., Neilands, J. B. Agrobactin, a siderophore from Agrobacterium tumefaciens. J. Biol. Chem., 1979, 254, 1860.

14. Peterson, T., Falk, K. E., Leong, S.A., Klevin, M. P., Neilands, J.B. Structure and behavior of spermidine siderophores. J. Am. Chem.Soc., 1980, 102, 7715.

15. Miller, M. J., Hu, J. Total Synthesis of a Mycobactin S, a Siderophore and Growth Promoter of Mycobacterium Smegmatis, and Determination of its Growth Inhibitory Activity against Mycobacterium tuberculosis. J. Am. Chem. Soc., 1997, 119, 3462.

16. Takeuchi, Y., Ozaki, S., Satoh, M., Mimura, K., Hara, S., Abe, H., Nishioka, H., Harayama, T. Synthesis of Acinetobactin. Chem. Pharm. Bull., 2010, 58, 1552.

17. Klein, D. R. Organic Chemistry. $1^{\text {st }}$ ed. New York: Wiley, 2013. pp. 407-408, 755, 800, 927 , 1000-1003.

18. Pétursson, S; Baldwin, J. E. Synthesis of $\delta$-(I-a-aminoadipoyl)-l-cysteinyl-d-(O-methyl)-dallothreonine a substrate for isopenicillin-N synthase and its O-methyl-d-threonine epimer. Tetrahedron, 1998, 54, 6001.

19. Montalbetti, C.A.G.N., Falque, V. Amide bond formation and peptide coupling. Tetrahedron, 2005, 61, 10827.

20. Sakakura, A., Umemuraa, S., Ishihara, K. Convergent total syntheses of fluvibactin and vibriobactin using molybdenum (VI) oxide-catalyzed dehydrative cyclization as a key step. Chem. Commun., 2008, 3561.

21. Atkins, G. M, Jr., Burgess, E. M. The reactions of an $\mathrm{N}$-sulfonylamine inner salt. J. Am. Chem. Soc., 1968, 90, 4744.

22. Holerca, M. N., Percec, V. ${ }^{1}$ H NMR Spectroscopic Investigation of the Mechanism of 2Substituted-2-Oxazoline Ring Formation and of the Hydrolysis of the Corresponding Oxazolinium Salts. Eur. J. Org. Chem., 2000, 12, 2257.

23. Phillips, A. J., Uto, Y., Wipf, P., Reno, M. J., Williams, D. R. Synthesis of Functionalized Oxazolines and Oxazoles with DAST and Deoxo-Fluor. Org. Lett., 2000, 2, 1168. 
24. Banala, S., Ensle, P., Süssmuth, R. D. Total Synthesis of the Ribosomally Synthesized Linear Azole-Containing Peptide Plantazolicin A from Bacillus amyloliquefaciens. Angew. Chem. Int. Ed., 2013, 52, 9518.

25. Spectral Database of Organic Compounds. Retrieved October 20th 2013 from SDBS: http://sdbs.db.aist.go.jp

26. Zinelaabidine, C., Souad, O., Zoubir, J., Malika, B., Nour-Eddine, A. A Simple and Efficient Green Method for the Deprotection of $\mathrm{N}$-Boc in Various Structurally Diverse Amines under Water-mediated Catalyst-free Conditions. Int. J. Chem., 2012, 4, 73.

27. Routier, S., Saugé, L., Ayerbe, N., Coudert, G., Mérour, J. Y. A mild and selective method for $N$-Boc deprotection. Tetrahedron Lett., 2002, 43, 589.

28. Blondelle, S. E; Houghten, R. A. Comparison of $55 \%$ TFA/dichloromethane and $100 \%$ TFA for Boc group removal during solid-phase peptide synthesis. Int. J. Peptide Protein Res., 1993, 41,522.

29. Kunishima, M., Kawachi, C., Monta, J., Terao, K., Iwasaki, F., Tani, S. 4-(4,6-dimethoxy1,3,5-triazin-2-yl)-4-methyl-morpholinium chloride: an efficient condensing agent leading to the formation of amides and esters. Tetrahedron, 1999, 55, 13159.

30. Winstanley, K. J., Smith, D. K. Ortho-Substituted Catechol Derivatives: The Effect of Intramolecular Hydrogen-Bonding Pathways on Chloride Anion Recognition. J. Org. Chem., 2007, 72, 2803.

31. McOmie, J. F. W., Watts, M. L., West, D. E. Demethylation of aryl methyl ethers by boron tribromide. Tetrahedron, 1968, 24, 2289.

32. Bergeron, R.J., Garlich, J. R., McManis, J. S. Total synthesis of vibriobactin. Tetrahedron, $1985,41,507$.

33. Bergeron, R. J., McManis, J. S., Dionis, J., Garlich, J. R. An efficient total synthesis of agrobactin and its gallium (III) chelate. J. Org. Chem., 1985, 50, 2782. 
34. Rastetter, W. H., Erickson, T. J., Venuti, M.C. Synthesis of Iron Chelators. Enterobactin, Enantioenterobactin, and a Chiral Analogue. J. Org. Chem., 1981, 46, 3579.

35. Housecroft, C. E., Sharpe, A. G. Inorganic Chemistry. $2^{\text {nd }}$ ed. Harlow: Pearson Education, 2005. 550-556. 